\title{
Mexico: 2010 Article IV Consultation-Staff Report and Public Information Notice on the Executive Board Discussion
}

Under Article IV of the IMF's Articles of Agreement, the IMF holds bilateral discussions with members, usually every year. In the context of the 2010 Article IV consultation with Mexico, the following documents have been released and are included in this package:

- $\quad$ The staff report for the 2010 Article IV consultation, prepared by a staff team of the IMF, following discussions that ended on February 12, 2010, with the officials of Mexico on economic developments and policies. Based on information available at the time of these discussions, the staff report was completed on March 1, 2010. The views expressed in the staff report are those of the staff team and do not necessarily reflect the views of the Executive Board of the IMF.

- $\quad$ A Public Information Notice (PIN) summarizing the views of the Executive Board as expressed during its March 10, 2010 discussion of the staff report that concluded the Article IV consultation.

The document listed below has been or will be separately released.

Selected Issues Paper

The policy of publication of staff reports and other documents allows for the deletion of market-sensitive information.

\author{
Copies of this report are available to the public from \\ International Monetary Fund • Publication Services \\ $70019^{\text {th }}$ Street, N.W. • Washington, D.C. 20431 \\ Telephone: (202) 623-7430 • Telefax: (202) 623-7201 \\ E-mail: publications@imf.org Internet: http://www.imf.org
}

\section{International Monetary Fund Washington, D.C.}




\title{
INTERNATIONAL MONETARY FUND
}

\section{MEXICO}

\section{Staff Report for the 2010 Article IV Consultation}

\author{
Prepared by the Western Hemisphere Department \\ (In consultation with other Departments)
}

Approved by David J. Robinson and Aasim Husain

March 1, 2010

\begin{abstract}
- $\quad 2008$ Article IV Consultation. The Executive Board welcomed the significant improvements in Mexico's fundamentals over the past decade. Directors also praised the authorities for adopting measured monetary and fiscal policy easing - carefully balancing the objectives of supporting activity and maintaining credibility — while letting the flexible exchange rate act as a key shock absorber. To address the medium-term fiscal challenges in the context of a falling share of oil revenue, further efforts were urged to strengthen revenues and restraints on current expenditure. Directors welcomed that the financial stability had been maintained, in part reflecting the strong regulatory framework and domestic funding base for banks. Advancing structural reforms were viewed as key to boosting growth prospects.

- $\quad$ Main Issues for 2010 Consultation. The 2010 consultation centered on near term policies to navigate out of the recession, and steps needed to support stability and potential growth over the medium term.

- $\quad \boldsymbol{F C L}$. An arrangement with Mexico under the FCL for 1,000 percent of quota (SDR 31.528 billion) was approved on April 17, 2009. The authorities have indicated their intent to treat the arrangement as precautionary.

- Mission. Discussions for the 2010 Article IV Consultation were conducted in Mexico City during February 2-12, 2010. The team met with Finance Secretary Cordero, Banxico Governor Carstens, other senior government officials, representatives from the private sector and think tanks. The team met with investors in New York during January 14-15, 2010.

- $\quad$ Team. This report was prepared by a staff team led by Vikram Haksar, comprising Kornelia Krajnyák, Ivanna Vladkova-Hollar, M.K. Tang, and Kristin Magnusson (all WHD), Giancarlo Gasha (MCM), Bikas Joshi (SPR), Geremia Palomba (FAD), and Andrea Medina (WHD).
\end{abstract}




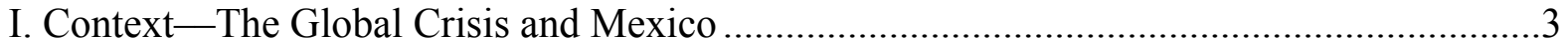

II. The Legacy of the Crisis and Policy Imperatives .....................................................

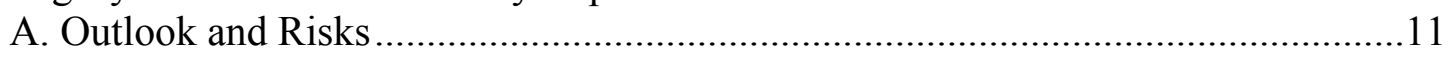

B. Exiting the Crisis - Near-Term Policy Requirements.......................................15

C. Beyond the Crisis —-Building a Robust Future................................................... 19

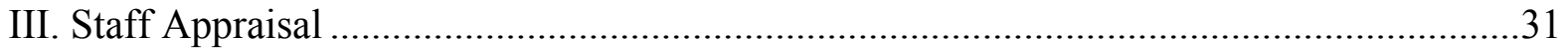

Boxes

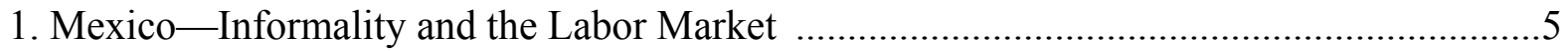

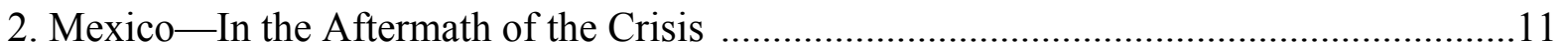

3. Mexico: Exchange Rate Assessments .............................................................................20

4. Directions in Global Regulatory Reform—Direct Implications for Mexico .....................26

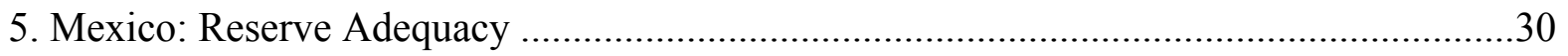

Figures

1. Mexico: Strong Performance: 1998-2008 ..................................................................4

2. Mexico: Impact of the Crisis on the Real Economy .....................................................6

3. Mexico: Financial Market Developments ..............................................................

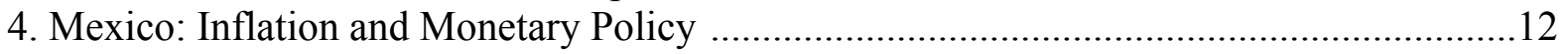

5. Mexico: External Sector-Current Account and Capital Flows ......................................14

6. Mexico: External Debt Sustainability: Bound Tests ....................................................15

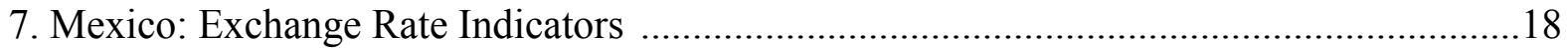

8. Mexico: Gross Public Debt Sustainability: Bound Tests ..............................................23

Tables

1. Mexico: Selected Economic, Financial, and Social Indicators, 2005-2011 ......................34

2. Mexico: Financial Operations of the Public Sector, 2005-2015 .....................................35

3. Mexico: Summary Balance of Payments, 2005-15 ......................................................36

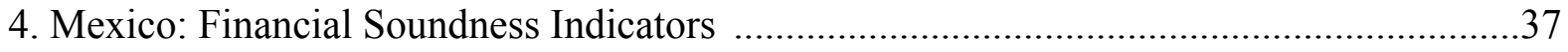

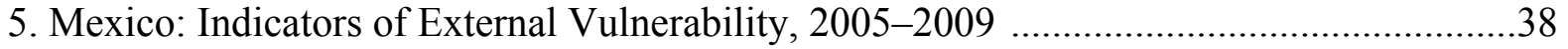

6. Mexico: Baseline Medium-Term Projections, 2005-2015 ..............................................39

7. Mexico: Gross Public Sector Debt Sustainability Framework, 2005-2015 .....................40

8. Mexico: External Debt Sustainability Framework, 2005-2015 ....................................41 


\section{ConteXt-The Global Crisis ANd MeXico}

Mexico faced the crisis from a strong position. However, the size of the Mexico specific shocks proved extremely large, including relative to key emerging market peers. Markets also saw constraints on the room for policy maneuver in Mexico. As such, risk premia rose in Mexico relative to other emerging markets in the wake of the crisis.

\section{Impact of the crisis}

1. Mexico entered the global crisis with greatly strengthened public and private sector balance sheets (Figure 1). Debt levels were much reduced with lengthened maturities, and reduced forex exposure. The banking sector was well capitalized with strong income generation and a low dependence on external financing. Most corporates had built important liquidity buffers with low overall and forex leverage. Policy frameworks - anchored by the balanced budget rule, inflation-targeting regime and a flexible exchange rate- - had achieved high levels of credibility. As such, compared to past crises, economic stability has been maintained, with the exchange rate and inflation remaining well anchored. While unemployment increased, it is also noteworthy that formal sector employment held up better than during previous crises (Box 1).

\section{2. $\quad$ Nonetheless, the Mexico specific external shock has been substantial, reflecting} strong real and financial linkages with the U.S. economy (Figure 2). With more than $3 / 4$ of exports directed to the U.S. and strong integration of production structures among the NAFTA countries, the collapse in U.S. industrial production quickly propagated to Mexico. Production and trade flows in the auto industry across North America dropped by 40 percent, and the decline in manufacturing activity was also synchronized. In Mexico, services activity also declined sharply - particularly in trade and transportation - reflecting the likely presence of strong cross-sectoral spillovers

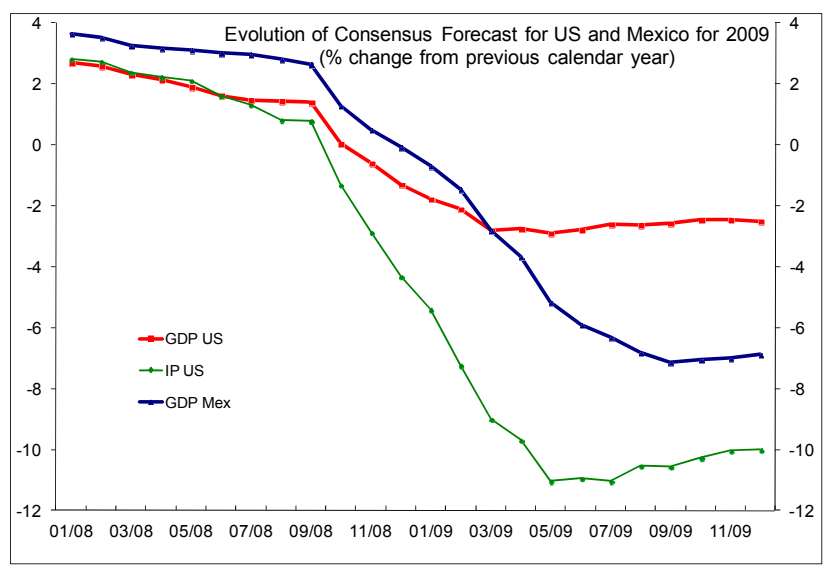
from manufacturing that exacerbated the collapse in output. ${ }^{1}$ Disruptions associated with the H1N1 outbreak in the second quarter are estimated to have subtracted an extra half a percent from annual growth.

\footnotetext{
${ }^{1}$ See also Box 3.3 “QQué Pasó? Behind Mexico’s Cycle, by Way of Comparison to Canada," Regional Economic Outlook: Western Hemisphere, October 2009.
} 
Figure 1. Mexico: Strong Performance: 1998-2008

Fiscal deficits have been reduced in the context of the fiscal rule

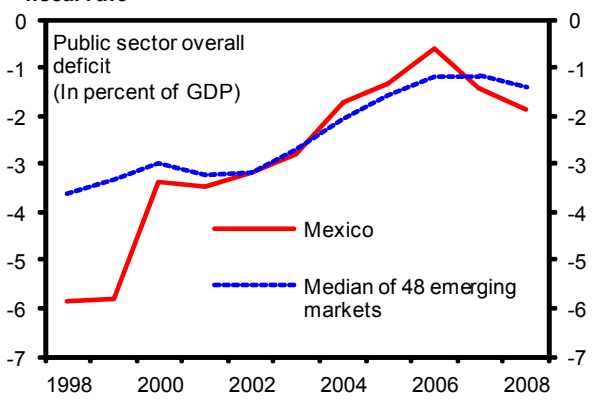

Public external debt also has fallen

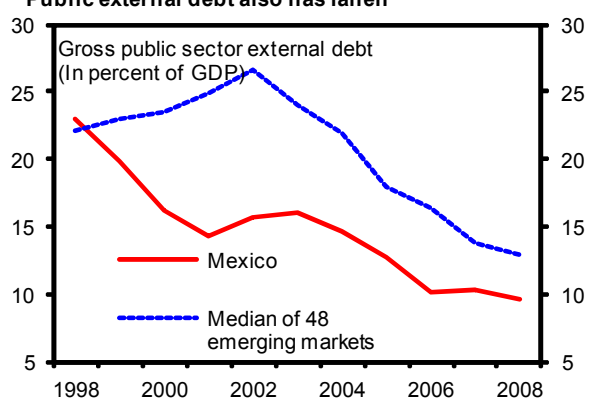

Private sector debt has fallen and use of natural hedges is increasing

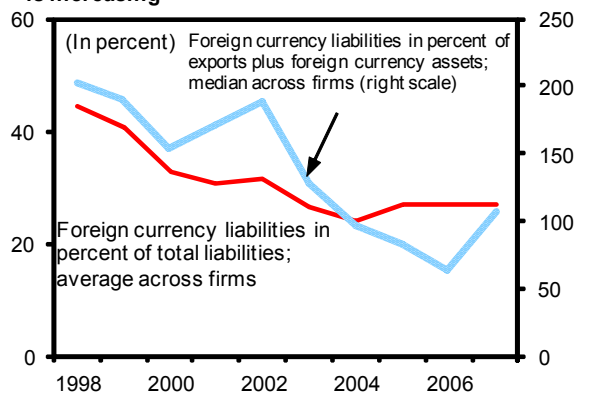

Likewise banks are well capitalized and have been profitable

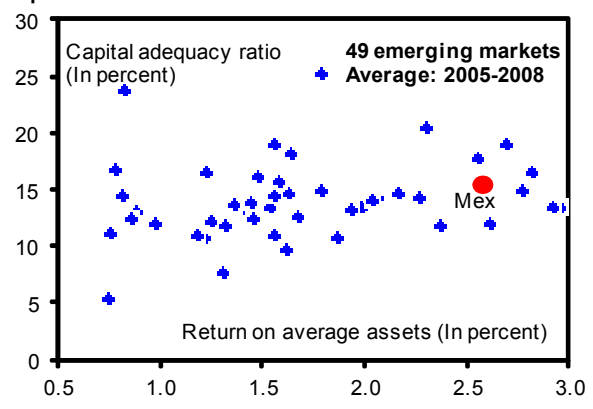

Public debt has also come down
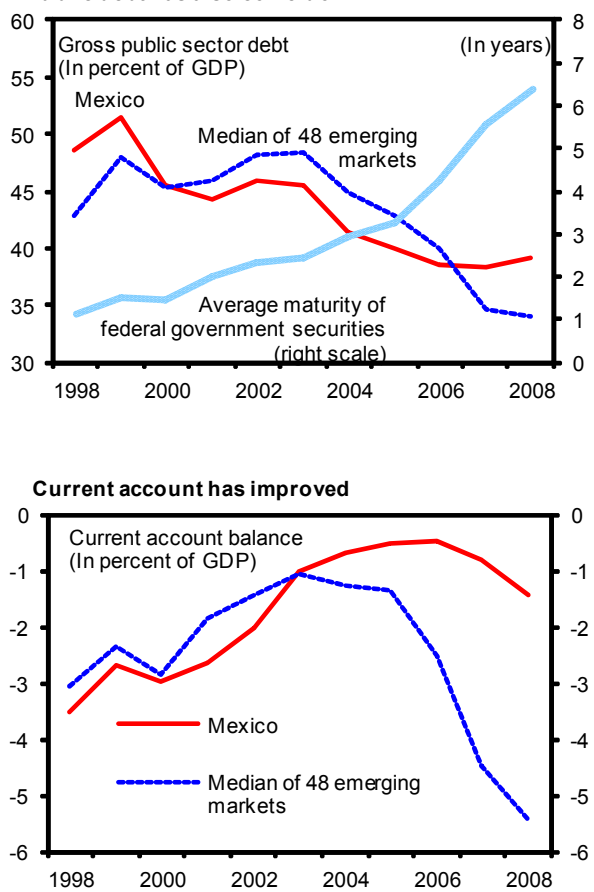

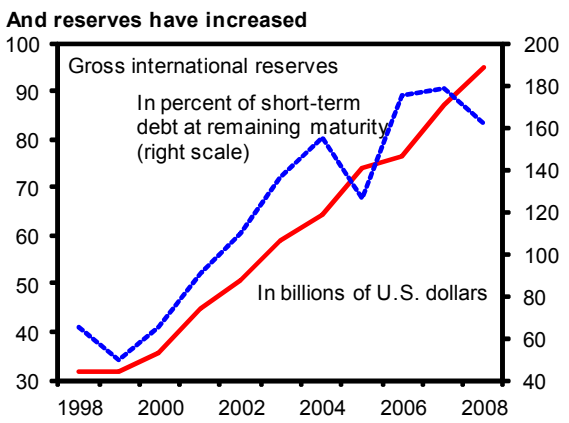

Sources: EMED; Haver Analytics; National auth orities; and IMF staff calculations 


\section{Box 1. Mexico-Informality and the Labor Market}

Labor markets deteriorated during the crisis, with unemployment climbing to its highest level since 2000. As a consequence, private consumption and retail sales staged large falls. While unemployment peaked at 6.4 percent in September 2009, private consumption was lagging until the third quarter and consumer confidence remains weak. Growth of real earnings is expected to be weak in 2010 with minimum wages increasing only slightly faster than forecasted inflation. Moreover, minimum wage increases not only provide a benchmark for a large share of formal sector wages, but also affect earnings in the informal sector where more than half of Mexicans are employed.

When Mexico faces economic downturns, the informal sector tends to buffer the blow to the formal sector. As seen from the left-hand panel of the figure below, the informal sector in Mexico typically increases its share of employment in recessions, something that is further confirmed by a negative correlation between the high-frequency variations in informal sector employment and GDP. Although the relative shares of informal and formal employment have been quite stable over the last two decades, the spike in informality induced by the 1994-95 recession took over three years to subside. It is noteworthy that informal employment and unemployment have increased less during the current crisis compared to then despite similar declines in output. Possible explanations for this positive outcome include the corporate sector's stronger resilience to shocks, the authorities' policy response and to a lesser extent a decline as opposed to an increase in labor force participation.

Increases in informal sector wages are unlikely to provide a major boost to private consumption as the recovery proceeds. After the 1994-95 crisis, the fall in the informal sector employment share and the reduction in the formal-informal sector wage gap were both slow and gradual. From the right-hand panel of the figure below, it is evident that while unemployment and the formal-informal sector wage gap have tended to move together, during the recovery from the 1994-95 crisis unemployment fell faster than relative wage differentials as activity rebounded. This time around, the output gap is projected to close only gradually over the medium term, such that it will likely take time before labor demand picks up and the formal sector recovers which in turn can allow informal sector wages to begin increasing in relative terms.

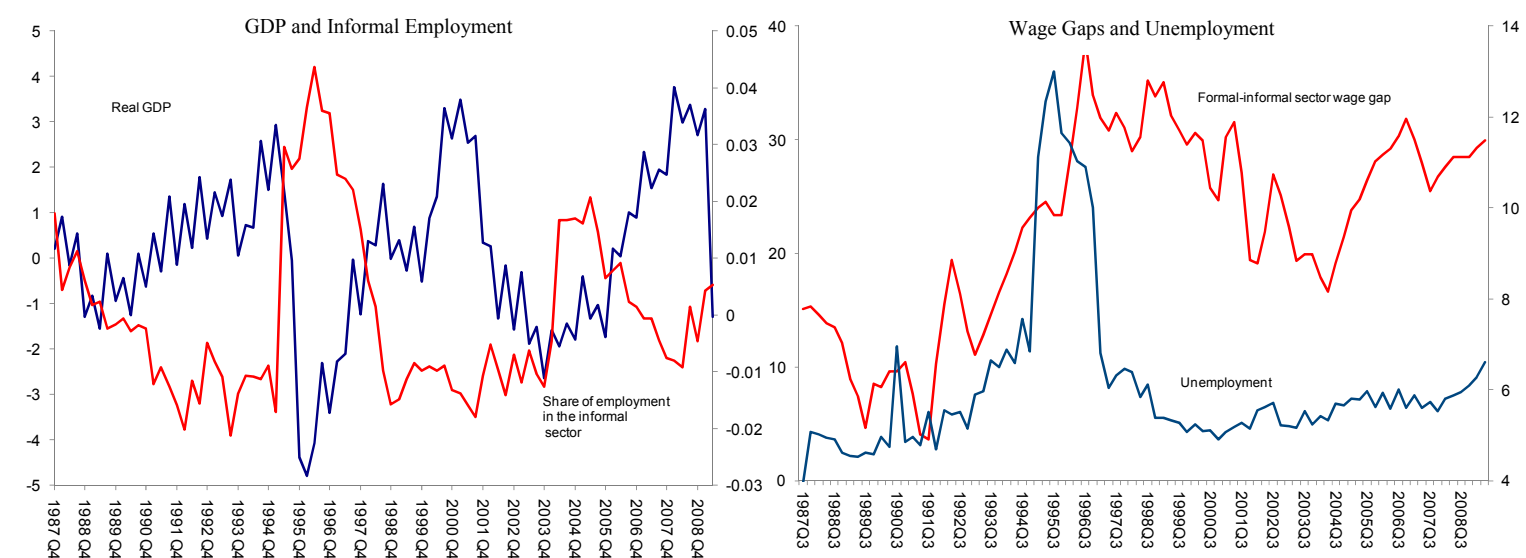

Left panel: Cyclical component of GDP (left axis) and informal employment (right axis), as measured by the HP-filter. Right panel: Formal-informal sector wage differentials (left axis) and unemployment (right axis), in percentage points. Series in the right-hand chart have been smoothed using a three-quarter moving average. Source: INEGI, IFS and staff calculations.

Prepared by: Kristin Magnusson Bernard 
Figure 2. Mexico: Impact of the Crisis on the Real Economy

The real economy was hard hit in the first half of 2009, but since then has begun to recover.

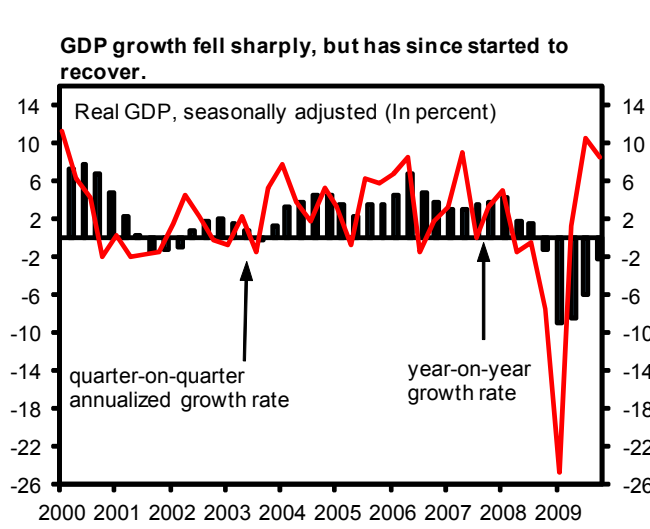

IP was particularly hit, particularly by disruptions in auto production, which has since turned around...
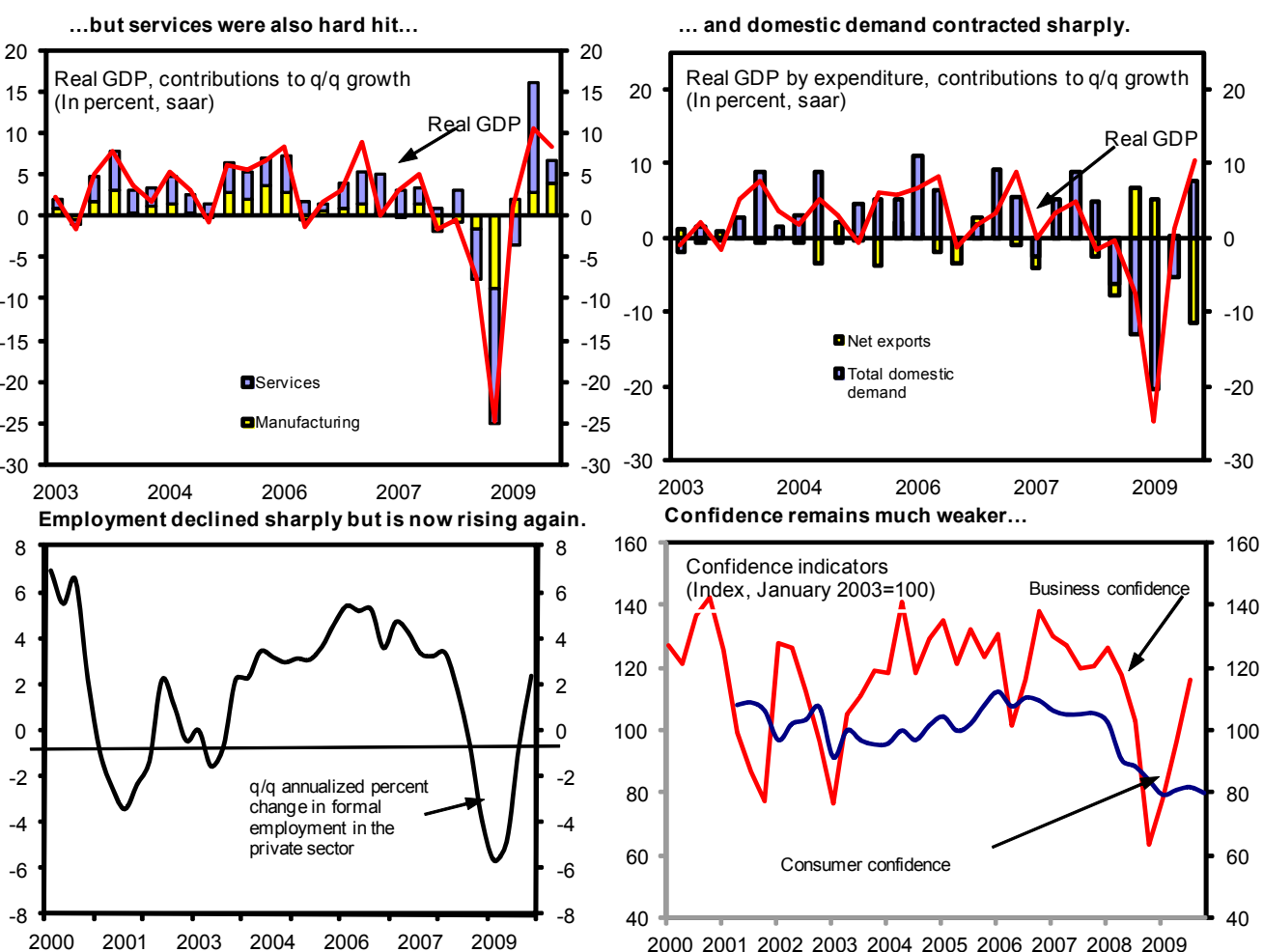

...and credit continues to slow.

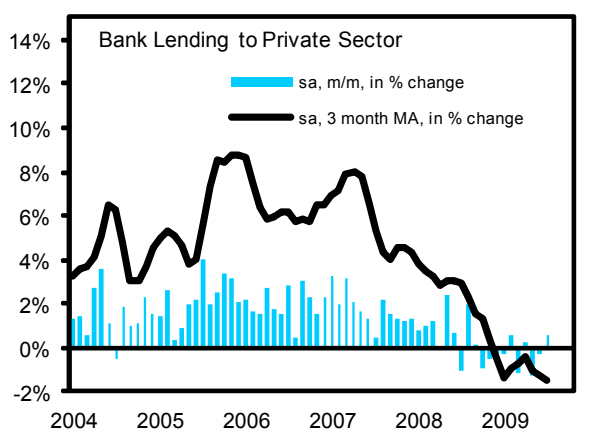

Overall, market expectations are increasingly for

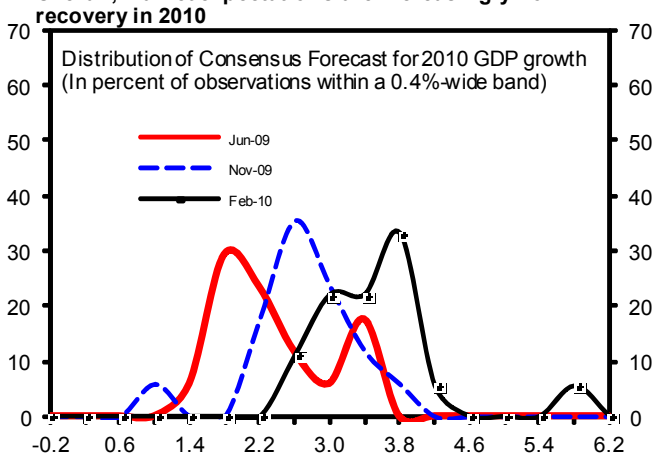

Sources: Consensus Forecasts; EMED; Haver Analytics; and IMF staff calculations. 


\section{Contracting activity and the sharply deteriorating external environment brought} about an abrupt reassessment of Mexico's near-term outlook. Large unexpected losses on corporate derivative exposures and refinancing difficulties for some large high profile Mexican corporates during November 2008-March 2009 weighed on sentiment. Indeed, market concerns regarding Mexico in the first quarter of 2009 were very much centered on the overall balance of payments outlook and availability of liquid foreign currency flows and buffers to tide over the crisis related financing stress. Sentiment vis-à-vis Mexico was further exacerbated in early 2009 (Figure 3) by the growing realization of the looming output crunch first manifested in the collapse of auto production for several weeks in December 2008January 2009. The FCL helped support sentiment when approved. Concerns resurfaced in mid-2009 with the prospect of ratings downgrades on account of concerns over fiscal and potential growth prospects. ${ }^{2}$ As discussed in IMF Country Report No. 09/53, the authorities mounted a broad-based and nimble policy response to contain the crisis-related economic stress. As such, stability has been maintained and the economy is now gradually emerging from recession.

\section{Some reflections on the crisis}

\section{This is the first time that a counter-cyclical policy response has been possible in} Mexico, though options were somewhat constrained. Fiscal policy has been eased substantially in 2009 and it is estimated that an impulse of about $2 \frac{1}{2}$ percentage points of GDP will have been delivered. Indeed, the fiscal impulse is in the upper half of G-20 emerging markets (Text Figure). Monetary policy too was eased significantly (375 bps since June 2008). Nonetheless, arguably, it might have been easier to sustain the fiscal stimulus had a higher level of savings of windfall oil revenues in the years ahead of the crisis been achieved. In addition, with state-owned development banks substantially smaller following the 1994-95 crisis, the

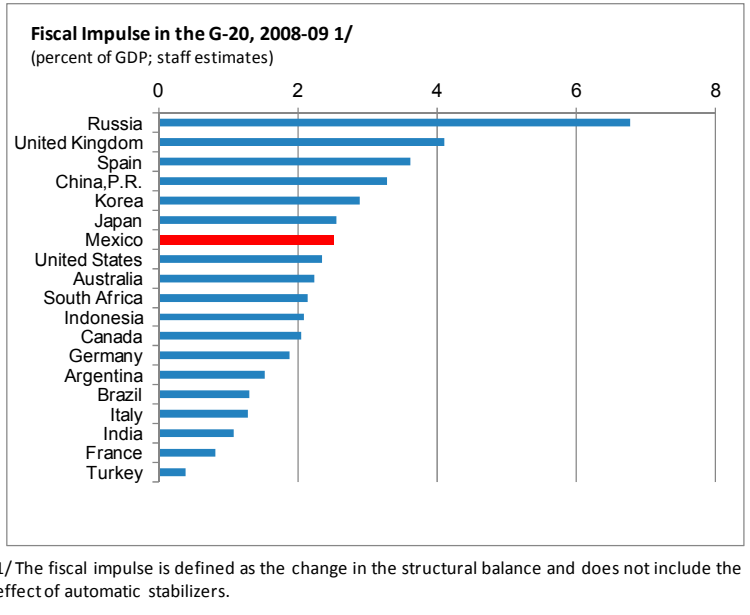
aggregate financial impulse delivered through these institutions in Mexico has been small relative to some other countries, though importantly, quasi-fiscal risks have also been more contained.

\footnotetext{
${ }^{2}$ In the event, Fitch and S\&P downgraded Mexico one notch to BBB with stable outlook in late 2009. Other developments in 2009 related to the FCL are discussed in IMF Country Report No. 09/126 and Country Report No. $09 / 302$.
} 
Figure 3. Mexico: Finan cialMarket Developments

Financial market conditions have improved with respect to peak levels of uncertainty observed during the height of the crisis.
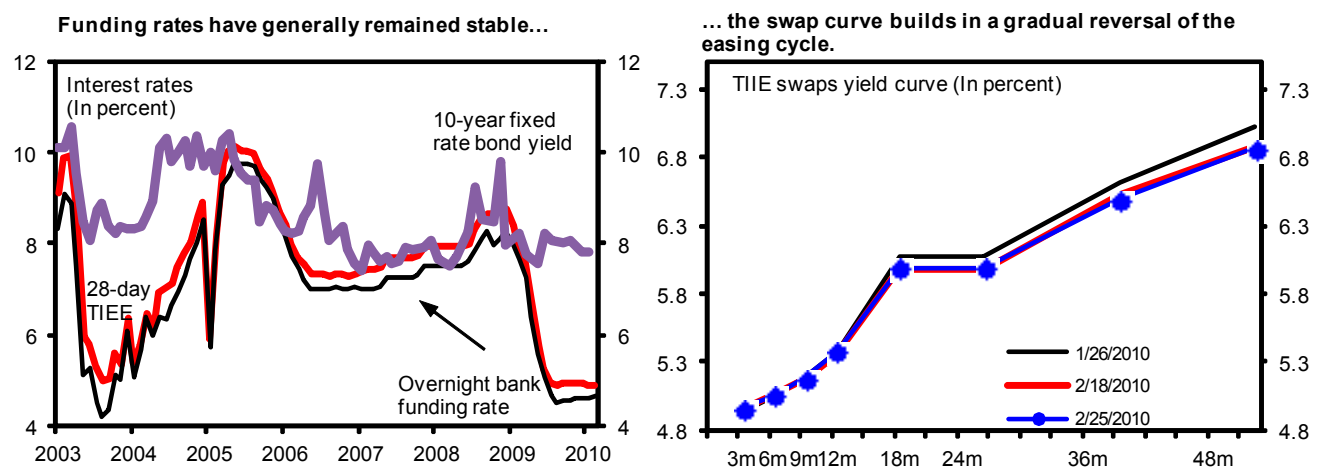

Risk spreads have come down but interest

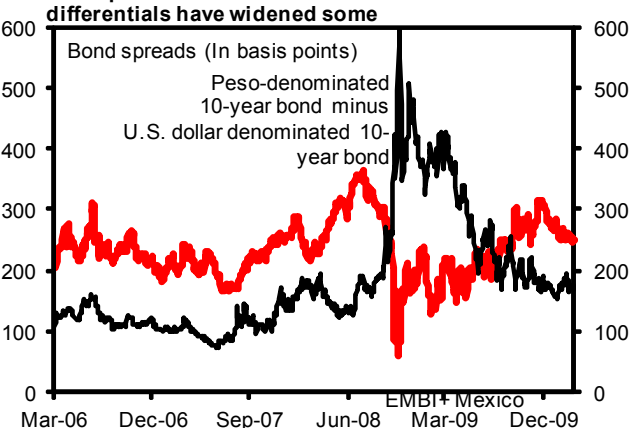

... in line with movements seen elsewhere..

...including with regards default premia .

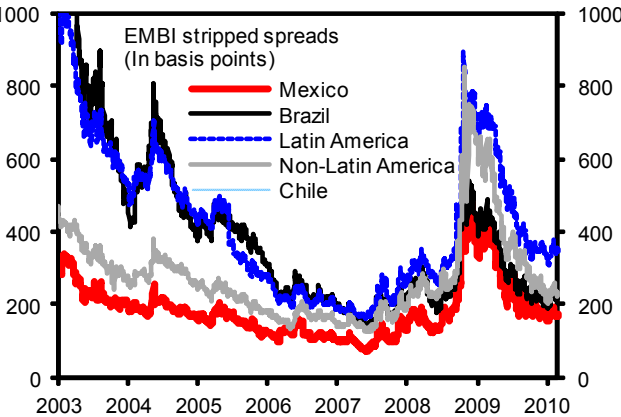

Term premia have come down ...
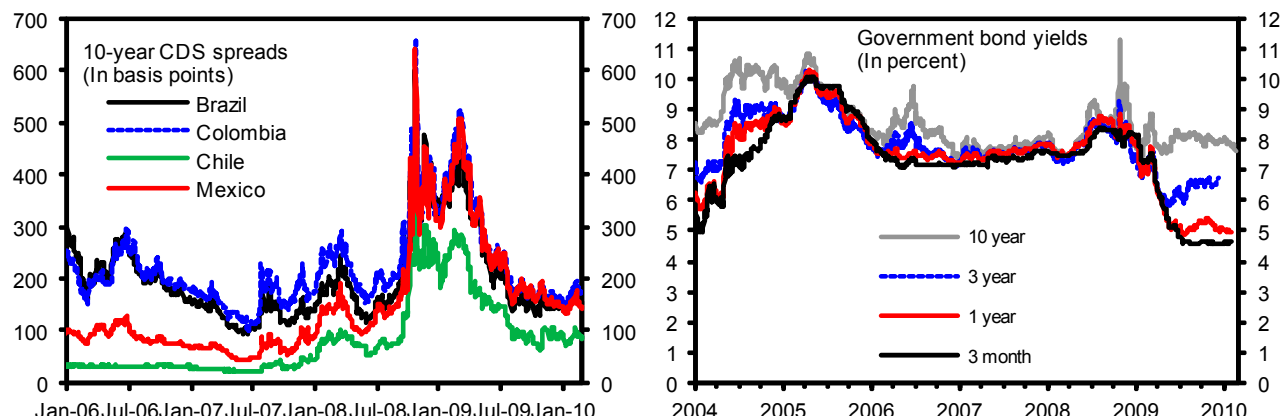

... while the yield curve has steepend some at the

Foreigners' ownership of government bonds has
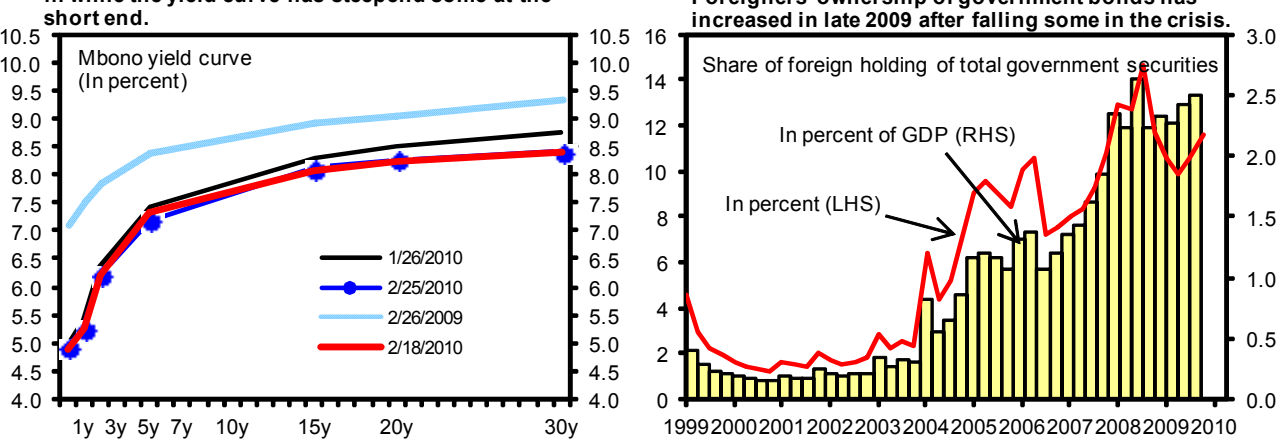

Sources: Bloomberg L.P.; Consensus Forecasts; Datastream; Haver Analytics; IMF Information Notice System; and IMF staff calculations. 


\section{Reserve levels were viewed as adequate before the crisis, though concerns were} raised in the face of the unprecedented large shock. The authorities intervened substantially in spot markets (US\$31.4 billion in total, with US\$11 billion auctioned off in a span of 10 days), in line with other emerging markets (though others engaged in larger non-spot interventions). However, with increasing market volatility, concerns about rollover prospects in the private sector, and uncertainty about the size of speculative derivative positions of a few big corporates, many investors viewed the available level of reserves as modest, noting that they were lower than in other emerging markets on balance sheet measures.

Establishment of precautionary financing lines - from the U.S. Federal Reserve (swap) and from the Fund (FCL) — served to assuage these concerns.

\section{The financial sector was generally resilient but some pressure points became} apparent. Aggregate banking sector ratios remain strong. However, two key issues became evident during the crisis. First, the sizable ownership of the local banking system by global banks could have increased transmission of external shocks. Credit growth has been decelerating since before the crisis, reflecting a pre-crisis retrenchment in consumer finance. Credit supply may have been further constrained by pressures on parent balance sheets in the case of some global banks. Second, non-bank intermediaries (accounting for at least 3 percent of system assets) have come under significant funding pressure. The authorities moved quickly to address the situation with the weakest institutions. As of end-June 2009, nonperforming loans in this sector stood at about $8 \frac{1}{2}$ percent of total loans, well above those of the banking sector.

\section{The Legacy OF The Crisis AND Policy ImPeratives}

\section{The crisis triggered an adverse shift in investor sentiment towards Mexico} reflecting vulnerabilities that were given new prominence. While Mexico's fundamentals do not appear to have been much worse affected relative to several peers in key dimensions (Box 2), relative risk perceptions seem to have deteriorated some. Concerns about risks to the medium-term fiscal outlook were heightened in light of growing uncertainties about the oil revenue outlook and sources of growth in the context of a weaker external environment. Indeed, potential growth in the advanced countries - especially the U.S. to which Mexico is closely linked - is likely to be significantly lower for several years as a result of the crisis. ${ }^{3}$ Worries about the level of reserves have emerged for the first time during this crisis. While the authorities have already started to address these concerns - see below - this underscores imperatives on strengthening the fiscal position, boosting growth, and reviewing reserve adequacy, which are at the forefront of the near term policy focus.

\footnotetext{
${ }^{3}$ Mexico continues to be far more dependent than other emerging markets on links to the U.S. (see Sosa, Sebastián, 2008, "External Shocks and Business Cycle Fluctuations in Mexico: How Important Are U.S. Factors?” IMF Working Paper 08/100).
} 


\section{Box 2. Mexico-In the Aftermath of the Crisis}

Relative risk. Despite recent improvements, Mexico's relative riskiness has increased post-crisis, while key fundamentals have not been notably affected, compared to a set of emerging market peers.

Fiscal outlook. The post-crisis fiscal outlook seems to have deteriorated somewhat more than LAC peers, but not relative to a broader EM peer group (and much less than in industrial countries). Mexico's debt stock will have risen by some 4 percentage points by 2013 , relative to the precrisis projection. The increase has also been contained by a cautious fiscal policy response, particularly in 2010 .

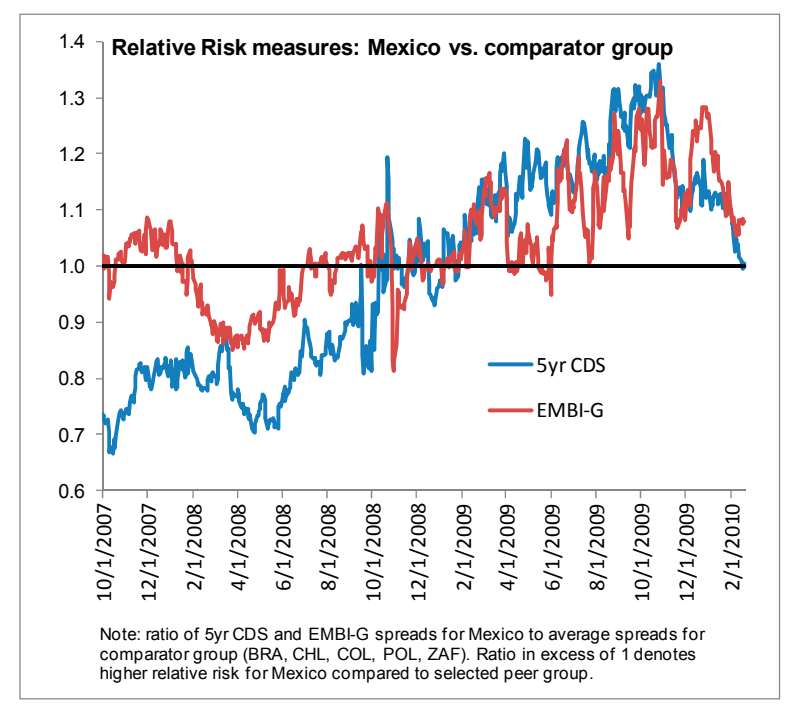

Growth outlook. The cumulative loss in output for Mexico relative to pre-crisis projections is large but not in stark contrast to peers. The level of real GDP now projected for 2013 is some 7 percent lower than the level projected pre-crisis. However, the outlook for potential growth in Mexico remains weak in comparison: potential growth, at about 3 percent, is the weakest in the group.

Thus, the deterioration in relative risk perhaps reflects a reassessment of underlying vulnerability to certain shocks and the room for policy maneuver. On the real side, Mexico's degree of integration with U.S., and the strong cross-sectoral spillovers from the manufacturing sector suggest a lack of diversification of sources of growth that accentuated Mexico's vulnerability to the growth shock in the U.S. On the fiscal side, oil price declines and the negative surprise on Figure. WEO Outlooks for Emerging Markets Before and After the Crisis
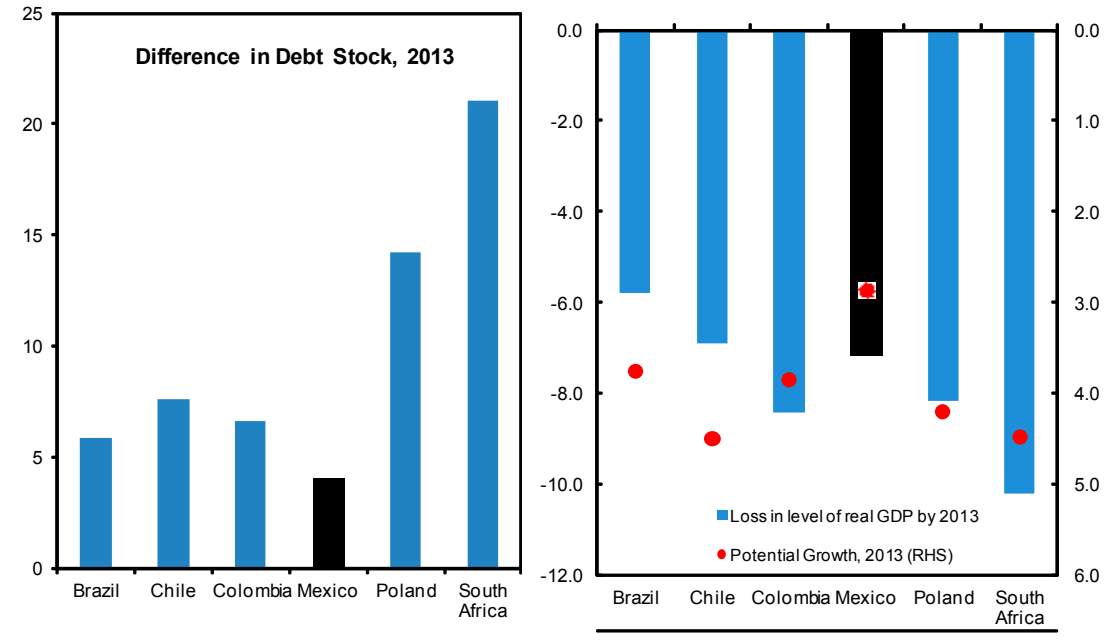

Source: IMF, World Economic Outlook and staff calculations.

The charts compare projections from the Fall 2009 WEO with projections in the Fall oil production in 2009 appear to have accentuated Mexico's medium term fiscal challenges. On the policy side, low fiscal buffers and slow-to-decline inflation have circumscribed somewhat the room for policy maneuver.

Prepared by: Ivanna Vladkova Hollar. 
8. The global environment facing Mexico over the medium term is also likely to be less supportive than in previous years. Risks to external financial conditions facing Mexico are on the up-side. Stricter regulation of global banks could also push up funding costs and reduce the scope for financial deepening in Mexico. Greater global volatility and risk aversion could result in higher risk premia. Combined, these factors raise risks for the cost of capital facing Mexico going forward. Moreover, base borrowing costs in advanced countries could rise in the face of increasing public debt.

\section{A. Outlook and Risks}

\section{Near-term growth in Mexico is expected to strengthen in line with the global} recovery. Growth rebounded in the second half of 2009, led by a recovery of manufacturing exports - especially auto production which is back to pre-crisis levels - and aided by a snapback in services activities as the impact of the H1N1 flu dissipated in the third quarter. Building on the momentum from end-2009, solid growth is expected in the first semester of 2010, gradually accelerating in the second half of the year as investment growth recovers on better global prospects and then consumer confidence picks up. With growth projected at an above-potential 4 percent rate in 2010 by staff and the authorities, and further accelerating to about $4 \frac{1}{2}$ percent in 2011 , the large output gap (estimated in the 7 to 10 percent range by the team and the authorities) starts to narrow but is only closed gradually over the medium term.

\section{While headline inflation is expected to rise temporarily above the target range,} underlying inflationary pressures are on a downward path (Figure 4). With inflation pressures subdued due to the large economic slack, and helped by falling non-core food prices, headline inflation has been on a declining trend in 2009 despite pass-through from the peso's depreciation in late 2008. At 3.6 percent, end-2009 inflation is still somewhat above Banxico's 3 percent target. Although the underlying downward trend is projected to continue, increases in administered prices and tax rates are expected to push-up the price level, and temporarily raise, inflation to the $4 \frac{1}{2}$ to $5 \frac{1}{2}$ percent range in $2010 .{ }^{4}$ However, second round effects - including on expectations - should be contained in light of considerable spare capacity, and indeed inflation expectations so far appear to be well-anchored. Inflation is expected to gradually decelerate towards target by end 2011 as the one-off effects dissipate.

\footnotetext{
${ }^{4}$ The authorities estimate that administered price increases linked to energy prices and the cost of certain local services will contribute about $1 \frac{1 / 4}{4}$ percentage point to inflation in 2010 . Tax measures in the 2010 budget are likely to add another $1 / 2$ percentage points to inflation in 2010 .
} 
Figure 4. Mexico: Inflation and Monetary Policy

Inflation has fallen gradually on the back of the large output gap which has allowed policy to be eased substantially

Inflation had been significantly above its 3 percent 14 target earlier this year,

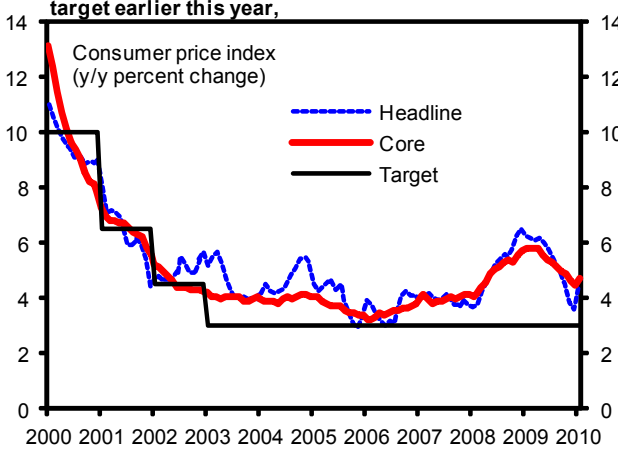

but the widening output gap...

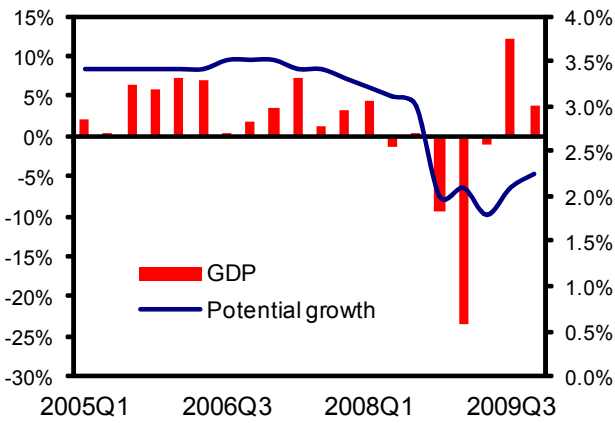

Real rates are broadly in line with the region.

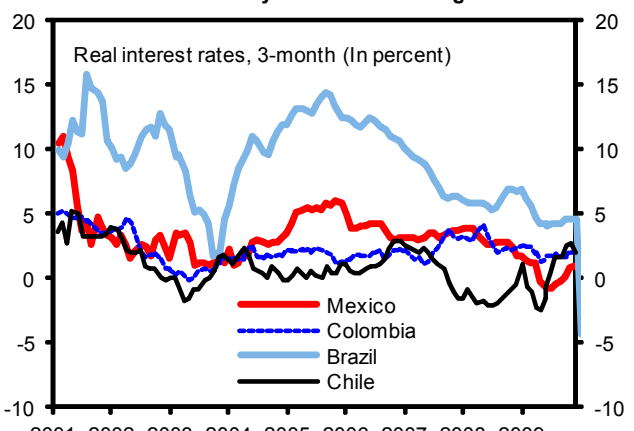

200120022003200420052006200720082009

Inflation is expected to rise in the near term, but long term expectations remain anchored.

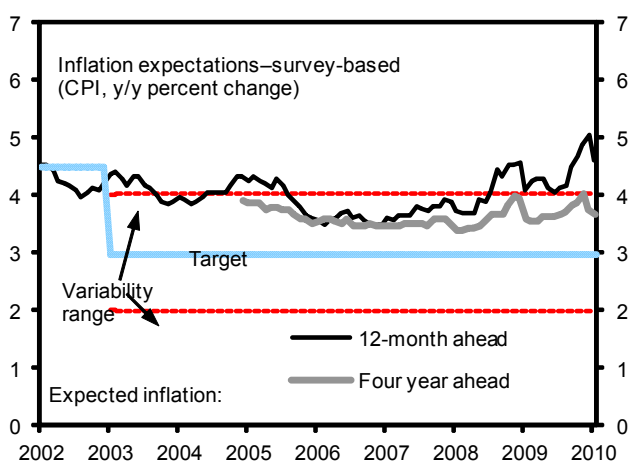

...partly due to rapid food price inflation...
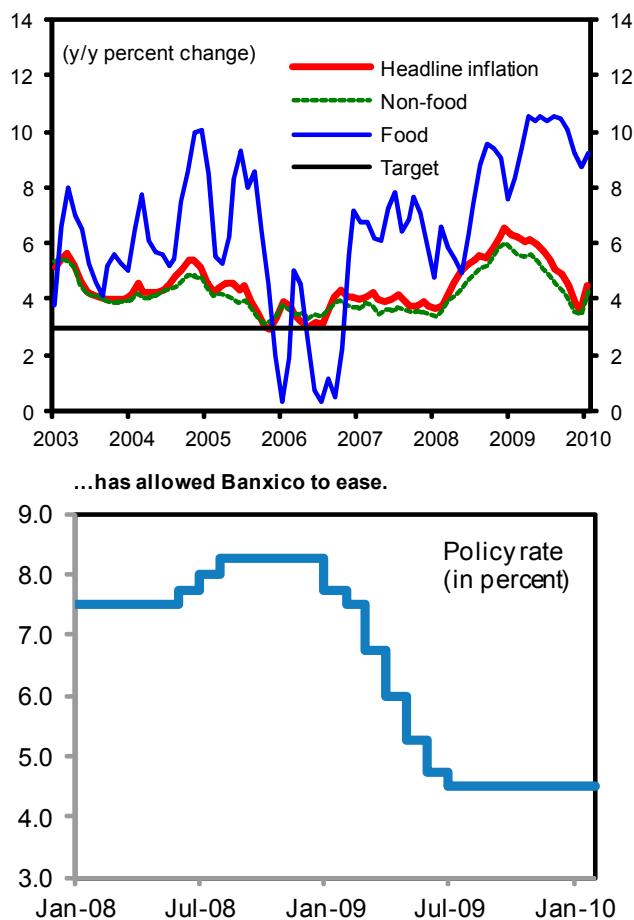

Wage growth has been fairly stable...

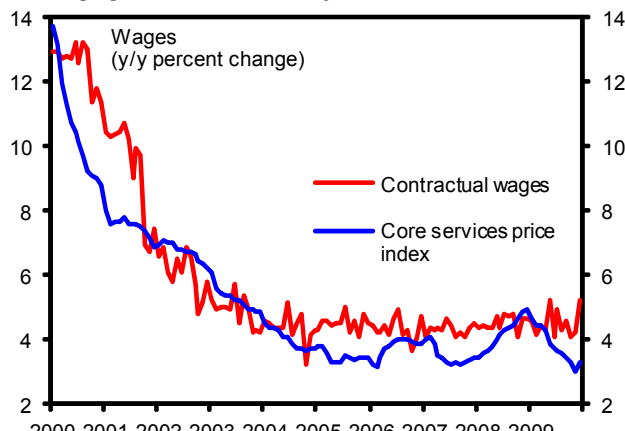

2000200120022003200420052006200720082009

...as evidenced too by the spread between nominal and inflation-indexed interest rates which has been around $4 \%$.

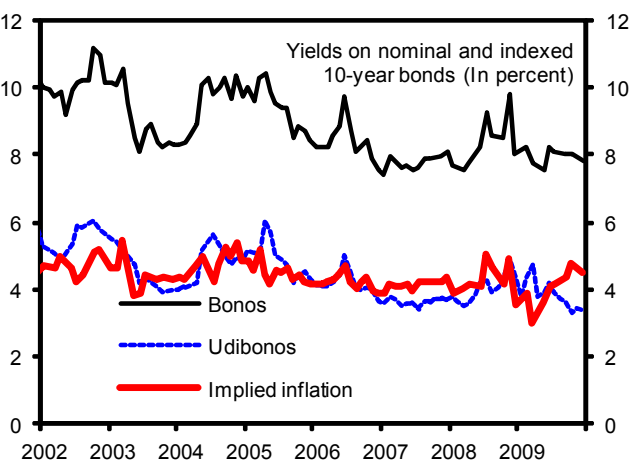

Sources: Bloomberg L.P.; Haver Analytics; INEGI; and IMF staff calculations. 
11. After declining in 2009, the current account deficit is expected to widen modestly, financed by a gradual increase in capital flows. The export decline during 2009 in the face of the global shock, was more than off-set by a sharp fall in imports on the back of declining domestic demand (Figure 5). Portfolio inflows picked up in the latter part of the year, though net FDI remained subdued. Over the medium term, net oil exports are projected to decline, with export volumes constant and imports growing in line with domestic demand, leading to some widening of the current account deficit. In line with a recovery in global sentiment, FDI and other inflows are also projected to resume in the baseline. Net international reservesboosted already by SDR allocations and receipts of the oil hedge in late 2009-are expected to rise steadily, largely reflecting the authorities' intent to retain the public sector's foreign exchange cashflow into reserves. Gross external debt remains manageable, about 18 percent of GDP over the medium term (see Figure 6 and Table 8).

\section{Near-term risks to growth are somewhat to the up-side, but tilt more to the}

downside for 2011. Upsides arise from the possibility of a faster-than-expected growth in 2010 in the US, including from possible

additional stimulus measures. For 2011 though, the team and authorities saw downside risks associated with weaker external demand and/or tighter global financing conditions. Of particular concern was the possible impact that the large global sovereign refinancing need could have on funding availability, especially from the latter part of 2010 onwards. Moreover, any upsides from policy stimulus in the U.S. in 2010 would

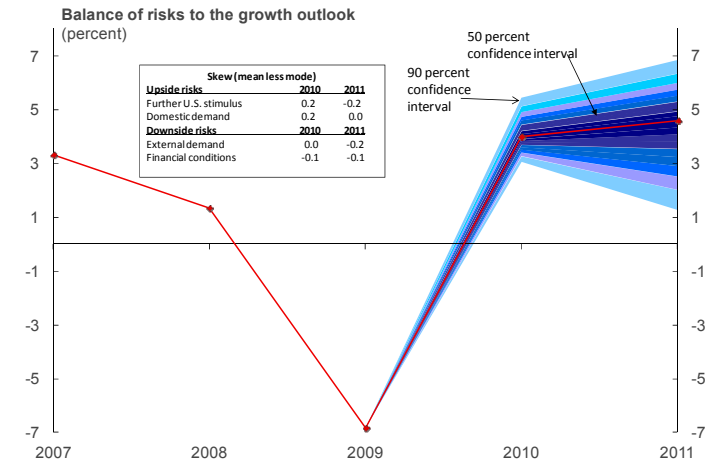
have payback to growth in 2011. Further, the possibility remains that feedback loops between the domestic credit cycle and activity may be stronger than currently projected.

13. Mexico's potential output growth is likely to have weakened. This is in part a direct result of the projected slowdown in U.S. trend growth over the next years. But the weakness in Mexican potential output growth also will likely reflect the impact of tighter financing conditions on capital accumulation and productivity growth (see Chapter I of the SIP), leading to a sizable cumulative output loss as a result of the crisis (Text Chart). Medium-term prospects would of course be boosted were the lasting global consequences of the crisis milder than expected, or structural reforms in Mexico to be advanced quickly. However, difficulties

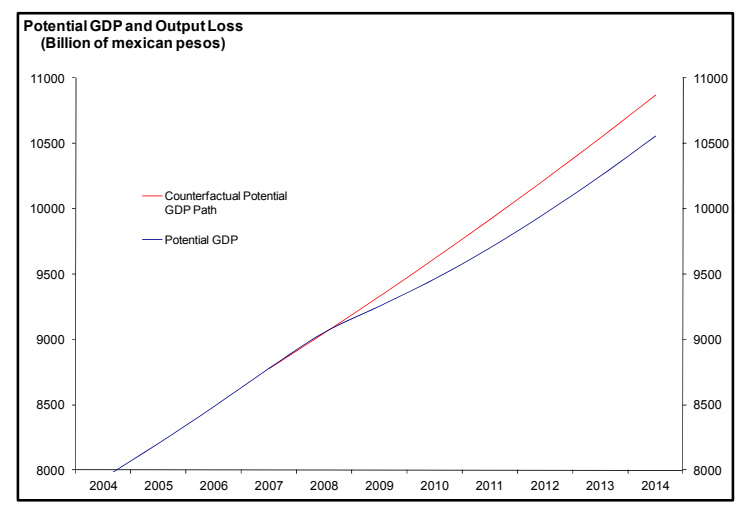
in building domestic consensus for reform ahead of the 2012 elections would be among the downside risks to the projected gradual recovery of potential growth. Furthermore, the security situation could also weigh on growth over the medium term. 
Figure 5. Mexico: External Sector - Current Account and Capital Flows
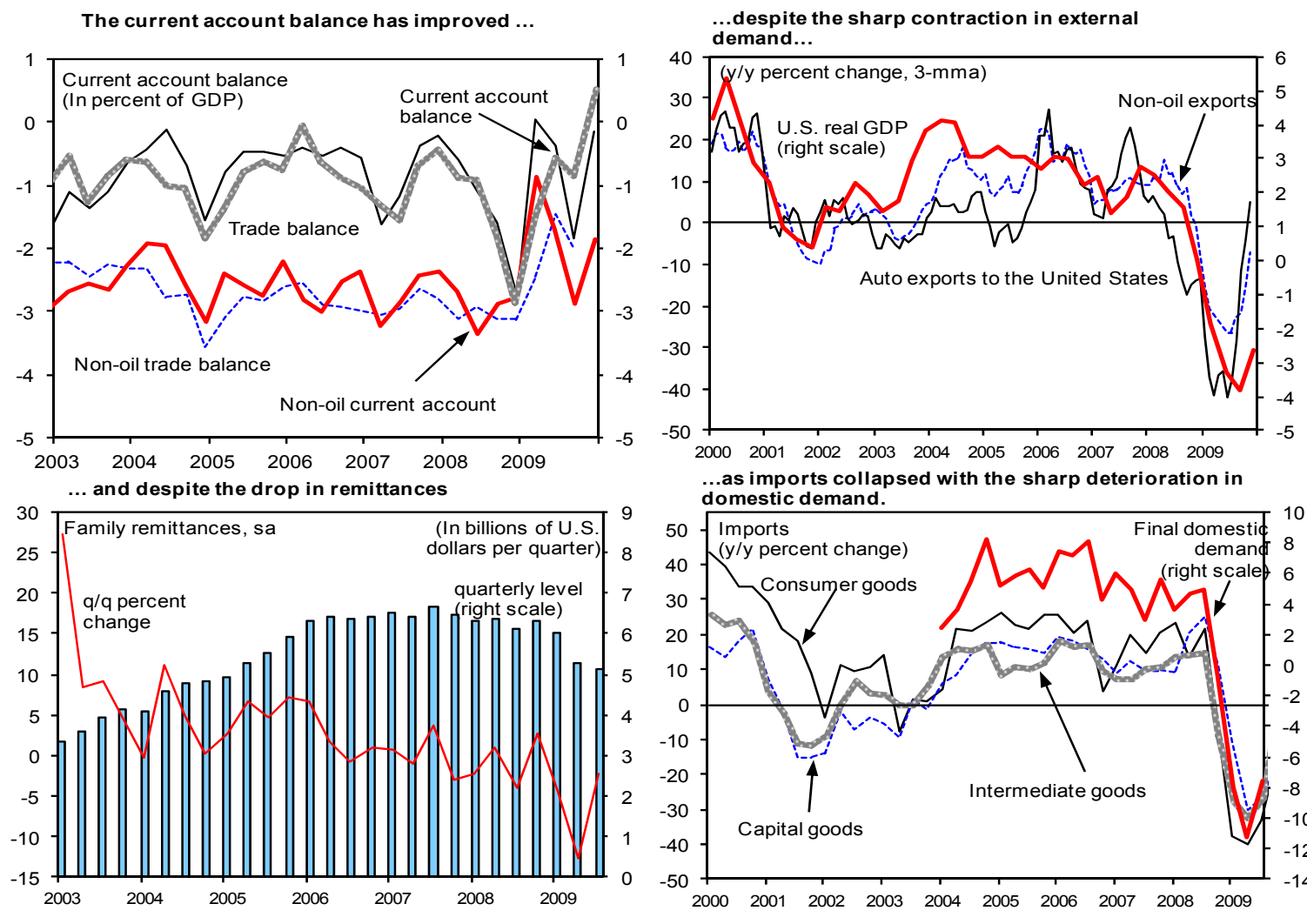

Private sector inflows have turned around some...
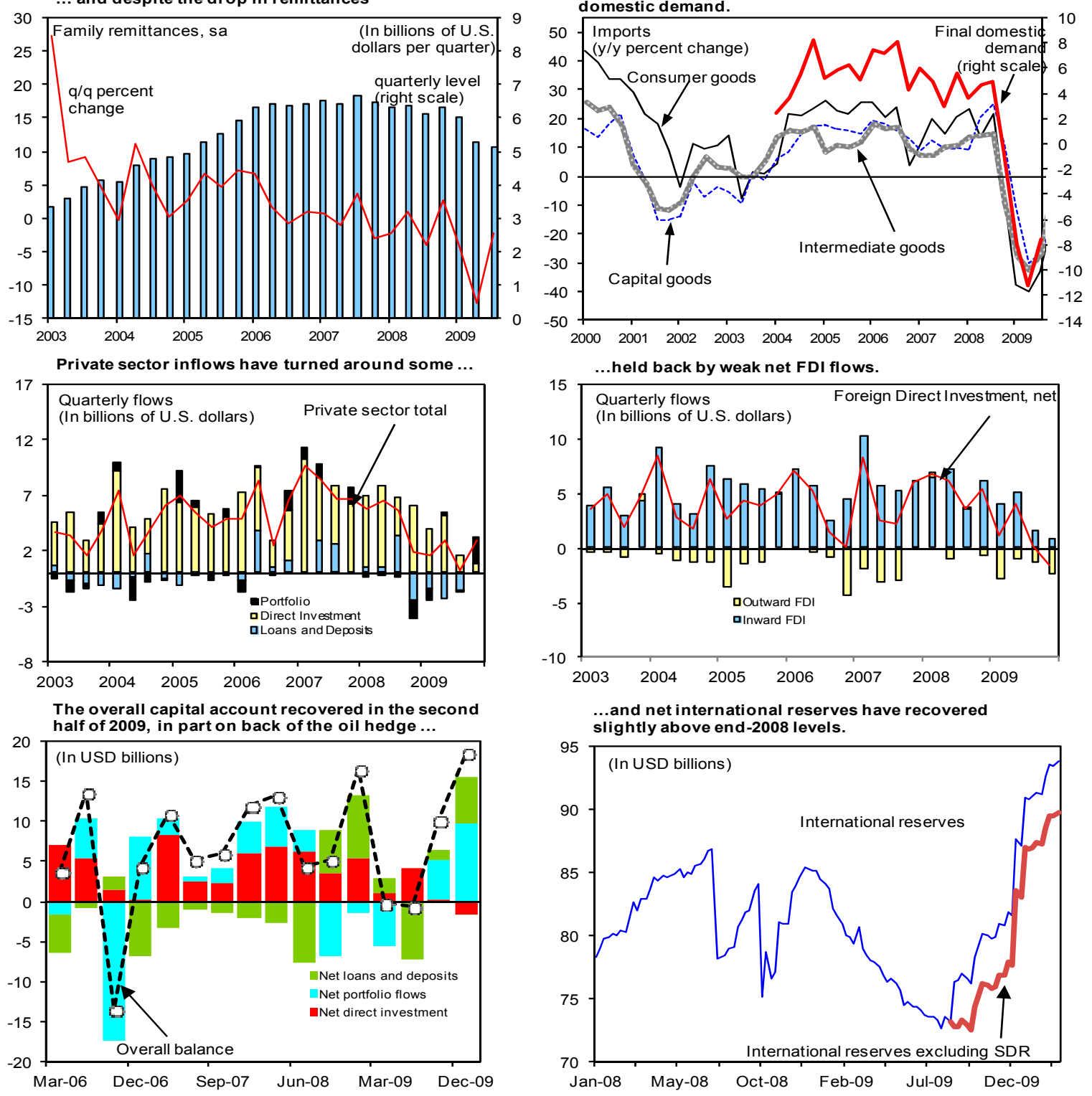

Sources: Mexican authorities; EMED; Haver Analytics; IFS; and IMF staff estimates. 
Figure 6. Mexico: External Debt Sustainability: Bound Tests 1/ (External debt in percent of GDP)
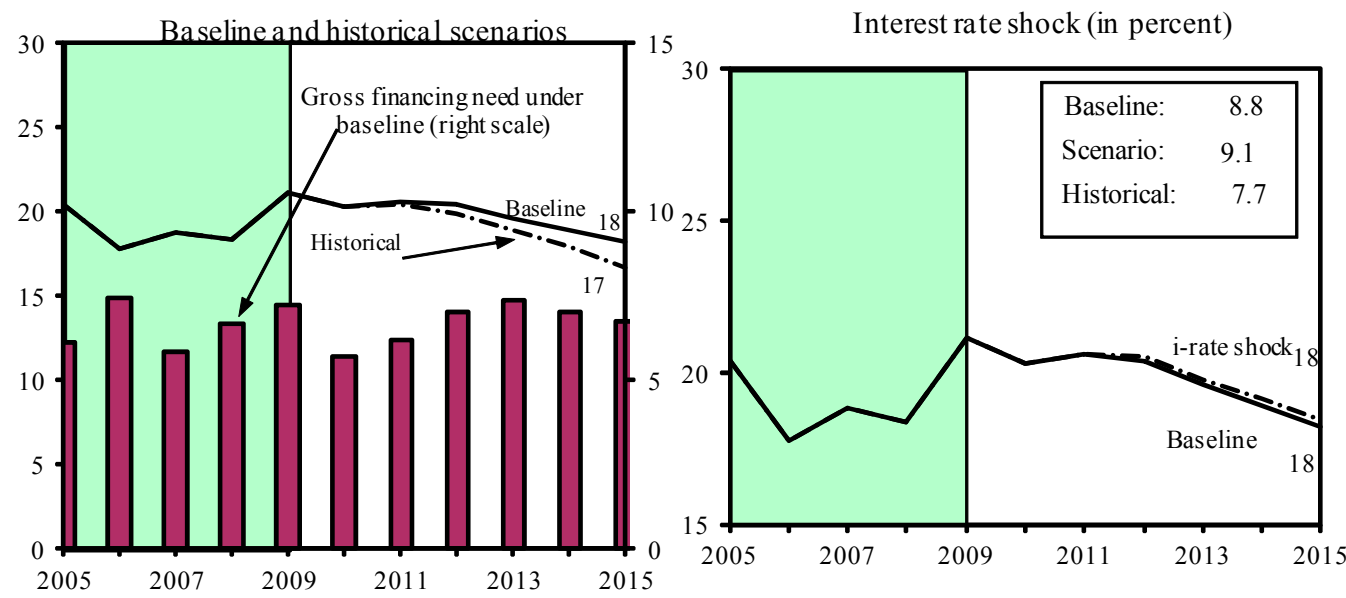

Growth shock (in percent per year)

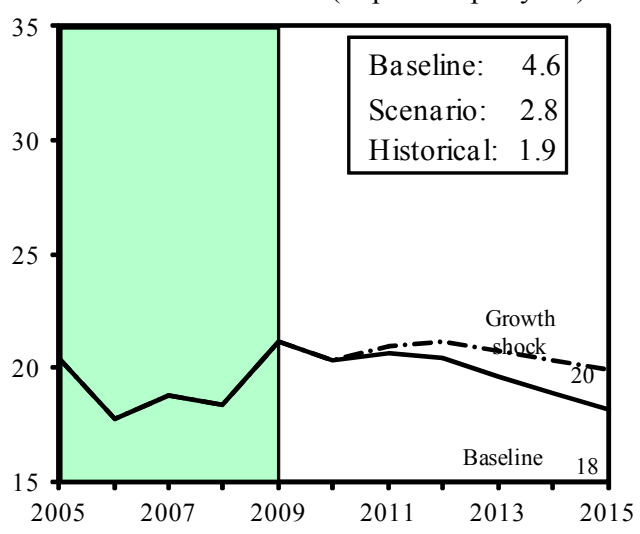

Non-interest current a ccount shock

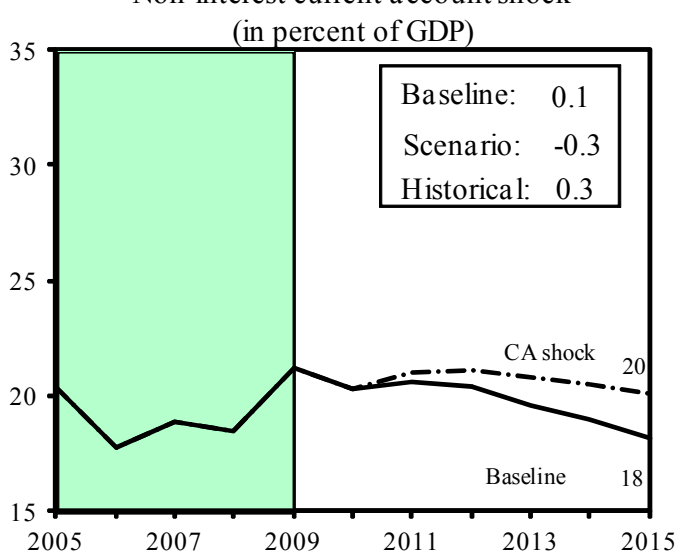

Combined shock 2/

Realdepreciation shock 3/
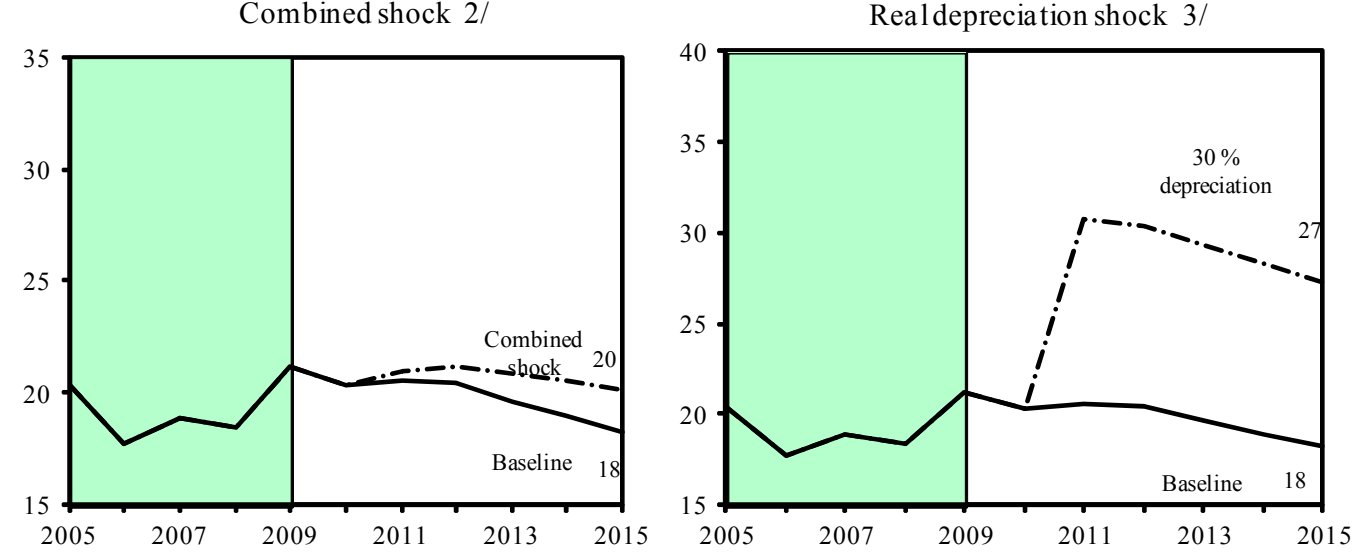

Sources: InternationalMonetary Fund, Country desk data, and staff estimates.

1 / Shaded areas represent actual data. Individual shocks a re permanent one-half standard deviation shocks. Figures in the boxes represent avera ge projections for the respective variables in the ba seline and scenario being presented. Ten-year historical a vera ge for the variable is also shown. 2 / Permanent $1 / 4$ standard deviation shocks applied to real interest rate, growth rate, and current account balance.

3/ One-time real depreciation of 30 percent occurs in 2010. 


\section{B. Exiting the Crisis-Near-Term Policy Requirements}

\section{Fiscal policy design in 2010 has had to balance the concern to avoid undue} withdrawal of stimulus, while providing assurances on medium term sustainability. Market concerns about the long run fiscal position last year-focused by sharply falling oil production - have circumscribed the authorities' ability to maintain the stimulus injected in 2009. Moreover, as presaged in last year's consultation, available room for easing fiscal policy in 2010 under the current rule is smaller compared to 2009. Exceptional revenues used in 2009-for example oil hedge operations, and central bank's profits, totaling about 11/2 percent of GDP — will not be available in 2010. Also, the authorities are seeking to maintain buffers in the oil stabilization funds (amounting to 1 percent of GDP at end-2009) to preserve room for maneuver against unanticipated shocks.

15. The authorities have adopted, and the team supported, a two-pronged approach to mitigate the withdrawal of fiscal support at a time when the recovery is not firmly entrenched while preserving medium-term fiscal sustainability. First, the 2010 budget includes an important tax package of about 1 percent of GDP to offset the deterioration in the structural revenue position linked to the decline in oil production. Moreover, the possibility of higher than budgeted oil prices creates some scope for additional upside savings. Second, they have for the first time invoked the exceptional circumstances clause allowing for a temporary deficit under the rule's "traditional fiscal balance" definition. The authorities approved a deficit of 0.7 percent of GDP for 2010 and 0.3 percent for 2011, which, together with some limited use of the resources from the oil stabilization funds, is in their assessment, calibrated to cover the cyclical deterioration in tax revenues.

16. The augmented deficit will fall from 4.7 to 3.4 percent of GDP between 2009 and 2010. This implies a withdrawal of stimulus of about 2 percent of GDP. The impact on demand is estimated to be smaller (about 1 percent on output growth), however, as the budget achieves consolidation through arguably lower impact revenue measures, while higher multiplier social and investment spending is preserved. The fiscal tightening will also help stabilize public debt and set the stage for its gradual

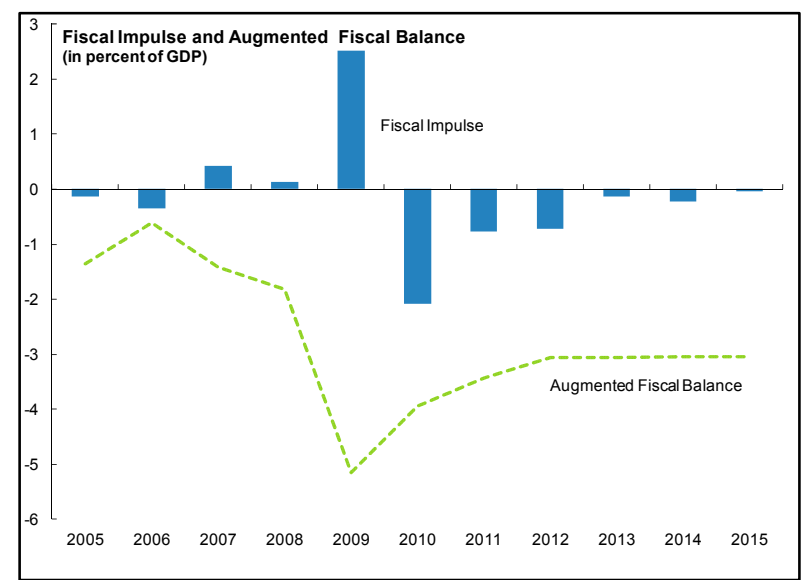
reduction over the next years. 


\section{The team noted that still weak demand conditions argued for maintaining} supportive near-term monetary policy settings. In of itself, the absence of signs of a strong rally in consumption or investment and the large output gap would suggest keeping an accommodative monetary policy stance until the recovery is firmly under way. But the team noted that the case for a macro policy mix tilted towards continued support from monetary policy was reinforced by the fiscal policy consolidation in 2010. The authorities have signaled their intent to maintain monetary policy support for the time being, noting that the projected upturn in inflation is due to one-off changes to the price level, and that the large output gap should contain second round effects. However, there was agreement that it was hard to predict the likelihood of second-round effects and Banxico is watching closely the development of expectations.

18. There continues to be a clear recognition that the flexible exchange rate regime has served Mexico well. The depreciation of the peso has absorbed some of the impact of the large external shock to demand and financing conditions. In contrast with previous episodes of large depreciations, stronger balance sheets and smaller currency mismatches have limited financial disruptions. However, there was agreement that large derivative-related losses in the corporate sector during 2008 were a sober reminder that new types of vulnerabilities have emerged in recent years. To safeguard against such risks, the authorities have acted promptly to strengthen disclosure requirements on derivatives and have enforced penalties against some of the affected companies.

\section{The authorities have continued to adhere to transparent rules-based intervention} mechanisms to maintain orderly liquidity conditions during the crisis. Two auction windows have been used this year, neither aimed at maintaining a particular level of the exchange rate. In the first, pre-announced volumes of foreign exchange were sold at the spot price, and in the second, liquidity up to US $\$ 400$ million was offered at prices linked to the spot rate. Altogether, Banxico made liquidity equivalent to about US $\$ 19$ billion available to the foreign exchange market through these mechanisms at a time when volumes have been substantially reduced. Since the crisis, peso volatility has undergone a level shift upwards that has shown no signs of fully reversing (Figure 7). This could be linked in part to continued lower levels of market liquidity, suggesting a continued role for rules-based liquidity facilities. The authorities have phased out the first facility, but have thus far maintained the other mechanism in place. ${ }^{5}$

\footnotetext{
${ }^{5}$ The cessation of daily sales since October 2009 and Banxico's absorption of the public sector net forex cashflow have allowed net international reserves to be built up to over pre-crisis levels, standing at $\$ 94.5$ billion end-February, 2010.
} 
Figure 7. Mexico: Exchange Rate Indicators

The peso market experienced considerable volatility in the inmediate aftermath of the crisis, but conditions have since improved.

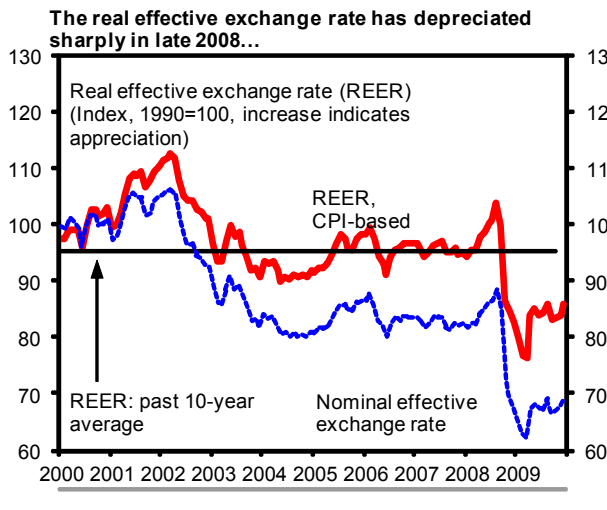

...though the peso has strengthened some after the initial overshoot

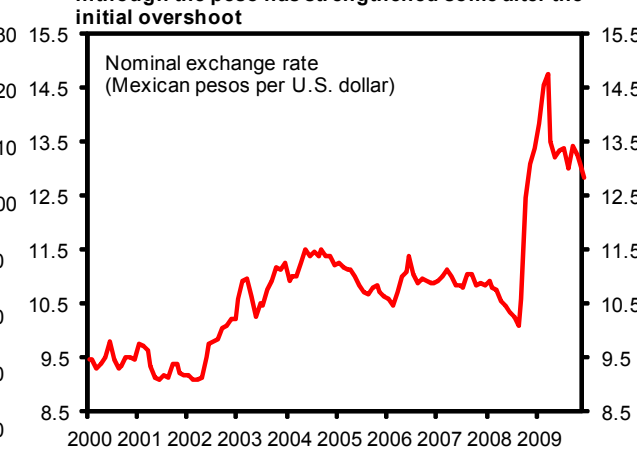

Interest rate differentials with the US have widened.

The risk premium on the currency has returned to

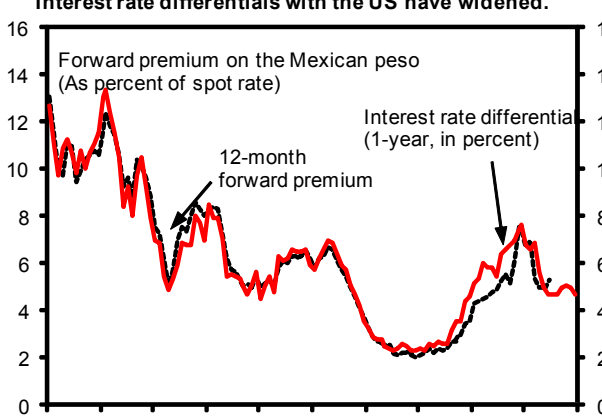
pre-crisis levels.

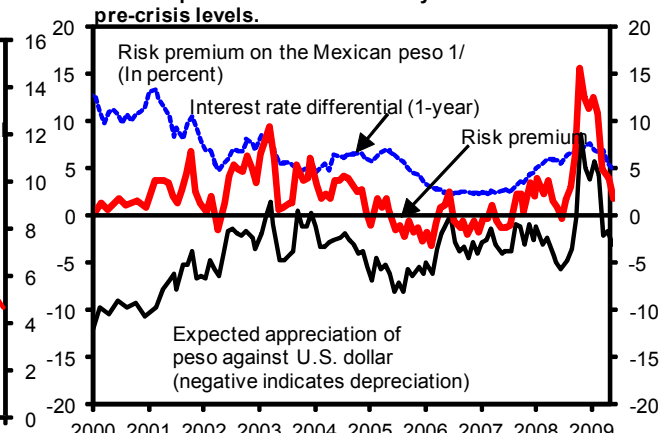

2000200120022003200420052006200720082009

Peso volatility spiked during the crisis, and remains

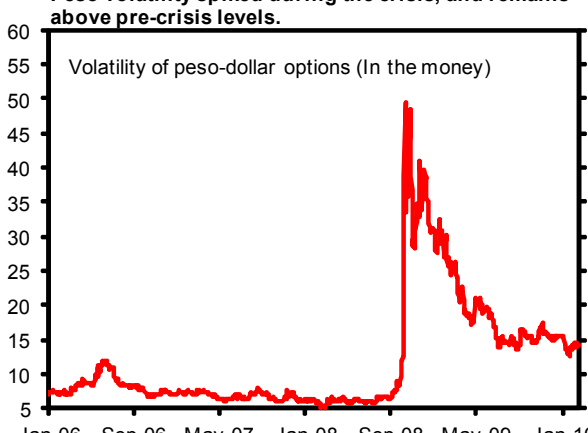

2000200120022003200420052006200720082009

Pove pre-crisis levels.

Jan-06 Sep-06 May-07 Jan-08 Sep-08 May-09 Jan-10

There has been some renewed build-up in peso foreign exchange positions.
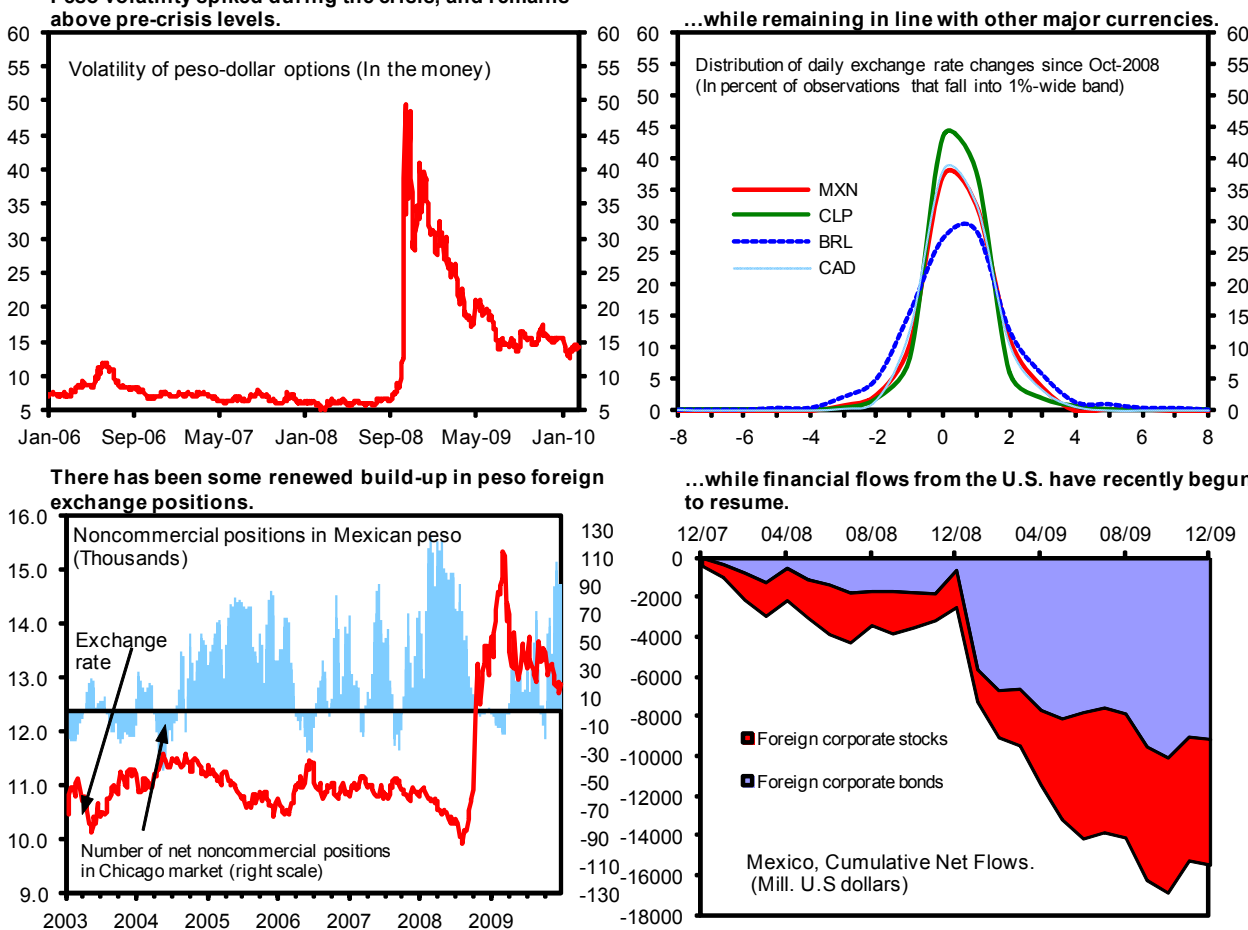

...while financial flows from the U.S. have recently begun to resume.

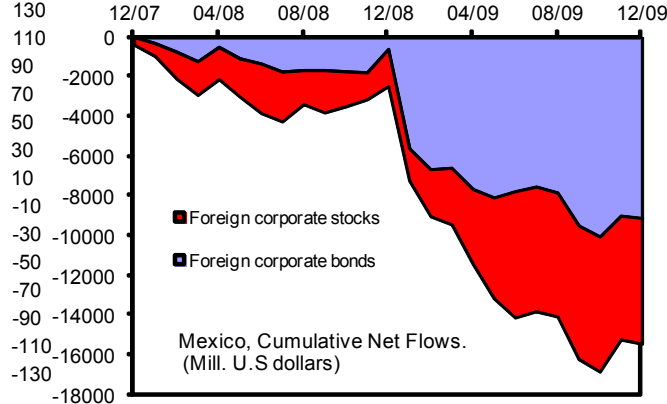

Sources: Bloomberg L.P.; Consensus Forecasts; Haver Analytics; IMF In formation Notice System; and IMF staff calculations.

1/ Risk premium is constructed as the difference between interest rate differential on 1-year CETES and 1-year U.S. T-bill rates and the Consensus Forecast expected 12-month-ahead depreciation of Mexican peso against the U.S. dollar. 
20. The team viewed the exchange rate as within the fair value range. Analysis based on the CGER methodologies suggested that the exchange rate had moved towards the strong side in mid-2008. The 15 percent depreciation of the real exchange rate since the Lehman bankruptcy has alleviated these concerns. Indeed, the team's analysis does not suggest a misalignment of the exchange rate at this time (Box 3). Relative price level based measures suggest that competitiveness may have been under pressures in the decade of the 2000's as China competed increasingly with Mexico in the U.S. market place and became a major supplier in Mexican markets as well. However, these competitiveness concerns have likewise been alleviated by the real depreciation. The authorities noted the uncertainty surrounding equilibrium exchange rate assessments, and stressed that the value of the peso remains market determined.

\section{Beyond the Crisis-Building a Robust Future}

\section{Strengthening the medium-term fiscal outlook}

21. Important reforms of the last three years have eased pressures on fiscal space. The tax reform packages of 2008 and 2010 combined are expected to raise the structural tax-toGDP ratio by a sizable 2 percentage points over time. ${ }^{6}$ However, in the team's mediumterm baseline, declining oil revenue and rising spending pressures, particularly for pension and social spending, may, if not addressed, unduly compress investment spending over time. While agreeing that there were pressures, the authorities noted that upside risks to revenue ratios (which fell sharply during the crisis) relative to the team's baseline might create additional space, while there was substantial space for

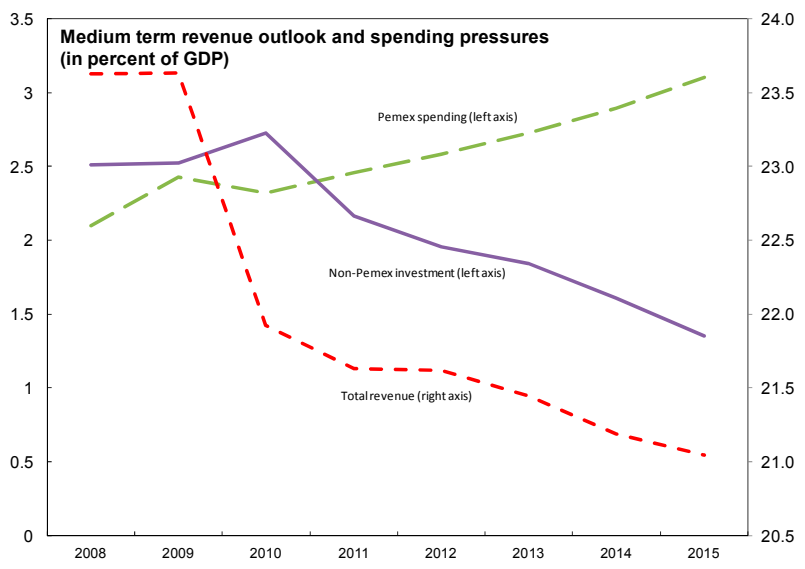
expenditure savings given the very rapid growth in current spending in the last years.

\footnotetext{
${ }^{6}$ The 2010 package increases the standard VAT rate by 1 percentage point to 16 percent, and contains increases in a variety of excise taxes, important changes in the tax treatment of loss-carry forwards, a temporary increase in income tax rates and revenue increases from improvements in tax administration. The resulting permanent revenue increase (about $2 / 3$ of the entire reform or 0.6 percent of GDP) delivers important consolidation.
} 


\section{Box 3. Mexico: Exchange Rate Assessments}

The peso's real effective exchange rate (REER) is considered to be broadly in line with fundamentals, with a range of estimates across methodologies. The latest semi-annual multi-country exercise of the IMF (CGER) shows Mexico's real effective exchange rate at about par value. ${ }^{1}$ These estimates reflect changes to both the exchange rates and the fundamentals since the start of the global crisis. The MB approach estimates a large decline in overvaluation, reflecting mostly the drop in the real effective exchange rates of almost 15 percent over the period. Additionally, changes in the projected output gaps in both Mexico and its trading partners and the fiscal balance have altered both the projected medium-term current

Mexico: Assessments across methodologies (in percent of equilibrium exchange rate)

Fall 2009 Fall 2008

\begin{tabular}{lrr} 
Macrobalance & 8 & 15 \\
ERER & -12 & 2 \\
External Sustainability & 1 & 10 \\
\hline
\end{tabular}

Overall Assessment

About 0 0-15 above

REER level at assessment

84.2 98.9 account deficit, reducing it by $1^{1} \beta$ percentage points of GDP and the estimated norm, bringing the two closer (thus reducing the overvaluation). Similar declines are also observed in the ERER and ES approaches. The baseline current account projection incorporates deterioration in the oil balance over the medium term of 2 percentage points of GDP; further deterioration over the longer term - in the absence of structural reforms - would have implications for the estimated REER.

In terms of assessments of competitiveness, these estimates may be complemented by use of additional indicators. The weighted-average relative price (WARP) methodology, for instance, gives another perspective on the evolution of competitiveness. Competitiveness indicators derived by this methodology (relative prices of import and export baskets) take better account of the growing importance of low-cost trading partners than "traditional" REER-type measures - a factor that may be particularly important when the structure of trade is changing fast. For example, the REER has remained significantly below its 2001 peak over the past decade, suggesting a sustained improvement in Mexico's competitiveness.

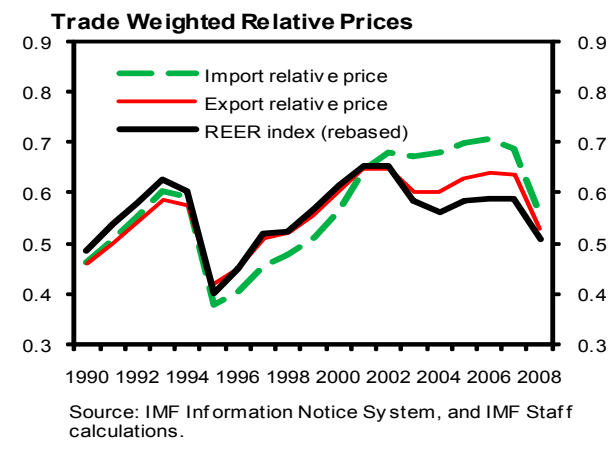

However, the export basket's price relative to trading partners was broadly stable over the same period, and - as the composition of imports shifted towards low-cost suppliers - the import basket's price relative to trading partners continued to increase until 2007. This suggests a less sanguine view of developments in external competitiveness over the past 10 years, though concerns have been alleviated by the real depreciation since 2008 (with relative export and import prices falling back to levels last seen around 2000).

\footnotetext{
${ }^{1}$ The methodologies for the exercise are described in IMF Occasional Paper No. 241. The current exercise had a reference period of August 2009.
}

Prepared by Bikas Joshi and Kornelia Krajnyak. 


\section{A key uncertainty remains the outlook for oil production, highlighting the} importance of successful implementation of the 2008 PEMEX reform. Oil receipts currently account for about one-third of federal revenues. Production seems to have stabilized after being in trend decline over the last years, with a series of downside surprises with respect to original budget projections. While there is a risk that the fall in oil output accelerates beyond current projections, the authorities noted that various technical factors and the scope for new investment gave reassurance that production will remain stable at current levels over the medium term. However, it

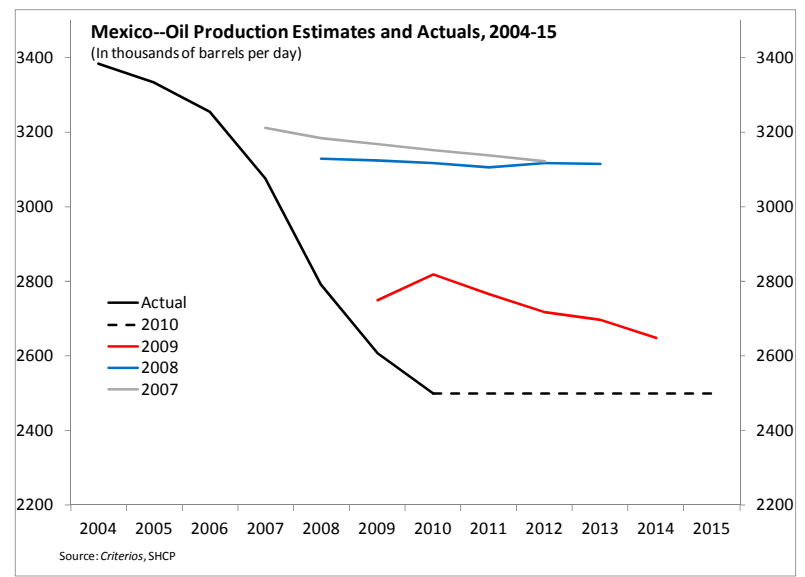
will be crucial to advance on the PEMEX reform, including releasing new incentive contracts for private investors to facilitate investment needed to decisively turn around the decline in production and proven reserves.

23. Given uncertainties on the oil production outlook, additional measures are likely to be needed over the medium term. In the near term, the authorities are focused on cutting current spending - which has grown very fast in the last years - and continuing with their tax administration reforms that have yielded strong results. ${ }^{7}$ Looking ahead, widening the tax base remains a priority, including reducing the extensive exemptions and zero ratings under the VAT and simplifying the personal and corporate income taxes. On the expenditure side, reforming untargeted energy subsidies, (electricity subsidies alone are estimated to cost some 1 percent of GDP) and moving towards a framework of medium-term spending planning are among the available options to generate savings. ${ }^{8}$

\section{Options for enhancing the fiscal framework}

\section{The current balanced-budget rule has served well to build credibility, but is} procyclical and provides limited scope for saving. The discipline of the rule has contained fiscal deficits and contributed to reductions in deficits and debt levels. However, rapid spending increases in the pre-crisis commodity boom years highlight scope for refinement. Booming oil revenues during 2003-08 underwrote average annual growth in real primary spending of 7 percent as savings in oil stabilization funds were capped at about $1 \frac{1}{2}$ percent of

\footnotetext{
${ }^{7}$ Keys here will be continuing the work on improving risk-based audits and collection of tax arrears, as well as introducing electronic invoicing in the immediate period ahead.

${ }^{8}$ Options on expenditure planning include measuring efficiencies, linking spending to outputs and outcomes, and improving prioritization, the budget preparation process, and monitoring of local government spending.
} 
GDP by end-2008. Moreover, the rule is asymmetric - the deficit can be increased in exceptional downside circumstances, but there is no mechanism for savings on the upside.

25. The team noted that a structural rule would reduce spending volatility over the cycle and could facilitate savings. Various alternatives are discussed in Chapter III of the SIP. The authorities were open to this idea, not least because it would further strengthen the credibility of the framework by introducing a symmetric response to output shocks. While in the near term they had focused their efforts on revenue measures, they had nonetheless removed caps on accumulation in the oil stabilization funds for 2010 as an initial step to promote savings. The team welcomed this and noted that as the output gap closes and tax stabilizers increase, it might be opportune to transition to a new structural rule to reinforce savings at the top of the cycle and also push debt ratios further down.

\section{A structural rule should be consistent with a steady reduction in debt ratios}

which-while manageable - remain above 2007 levels. The gross debt ratio is expected to peak in 2010 at about 45 percent of GDP, dropping gradually to about 42 percent of GDP by 2015 (net public debt is projected at a lower level of about 38 percent of GDP by 2015).

Moreover, the standard debt sustainability analysis (Figure 8 and Table 7) shows that even if fiscal policy were not constrained by the rule in the event of shocks, debt levels would still remain manageable in the medium term. The team noted that in reviewing the fiscal framework it would also be important to consider medium term debt goals and what this might mean for the primary adjustment profile.

\section{Financial stability}

\section{Like other emerging markets in Latin}

America, the core Mexican financial system has come through the crisis relatively well. Pressure on capital ratios and profitability has been manageable. While the system is heavily exposed to cross-border ownership (see $\$ 30$ ), the bulk of funding is sourced from domestic retail sources that has provided a key source of stability especially in the face of the global funding shocks affecting systems in advanced countries and other emerging markets.

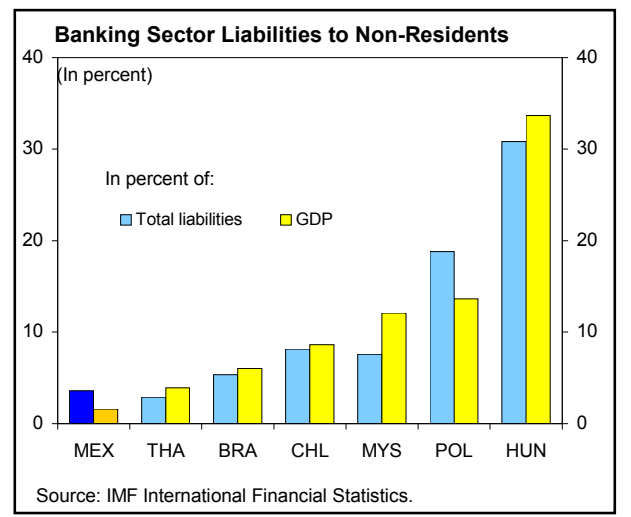


Figure 8. Mexico: Gross Public Debt Sustainability: Bound Tests 1/ (Gross public debt in percent of GDP)

Baseline and historical scenarios

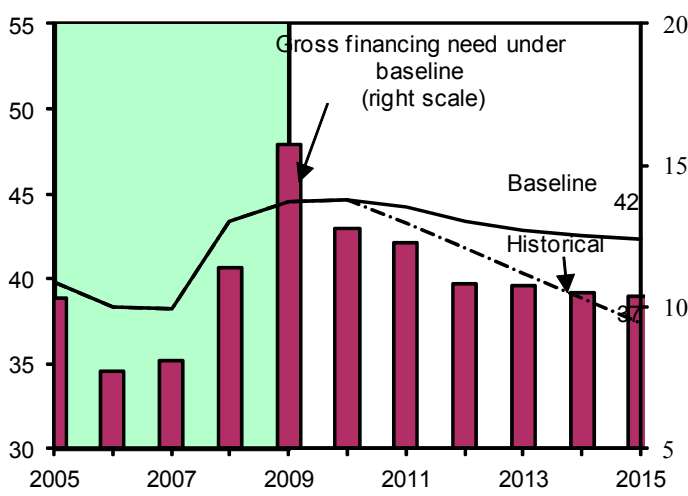

Growth shock (in percent per year)

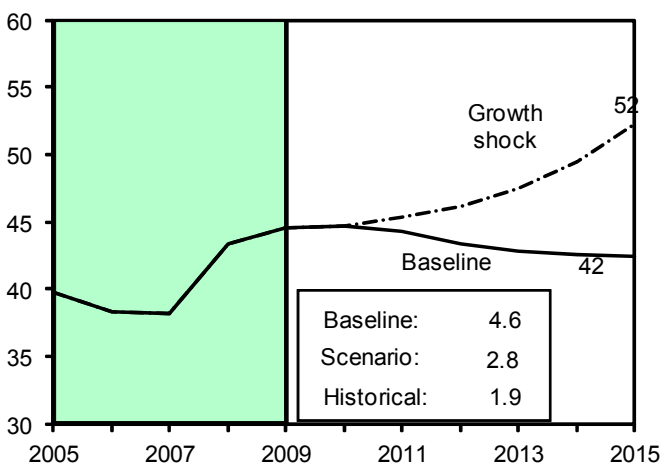

Combined shock 2/

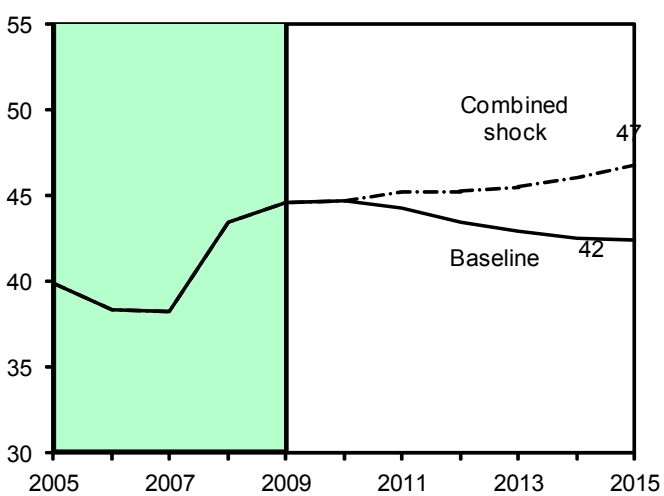

Interest rate shock (in percent)

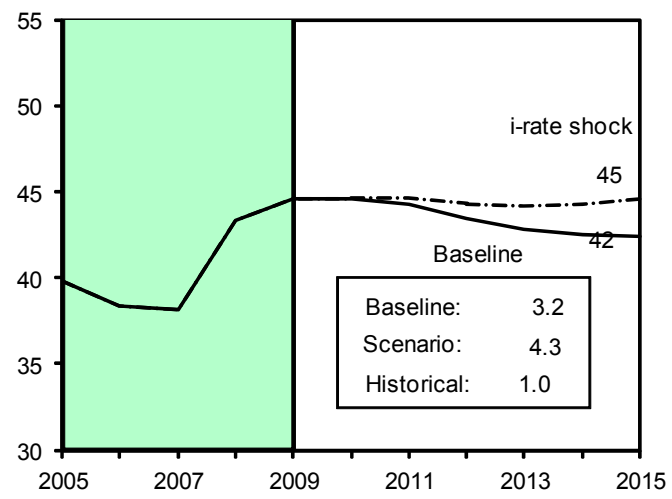

Primary balance shock (in percent of GDP) and no policy change scenario (constant primary balance)

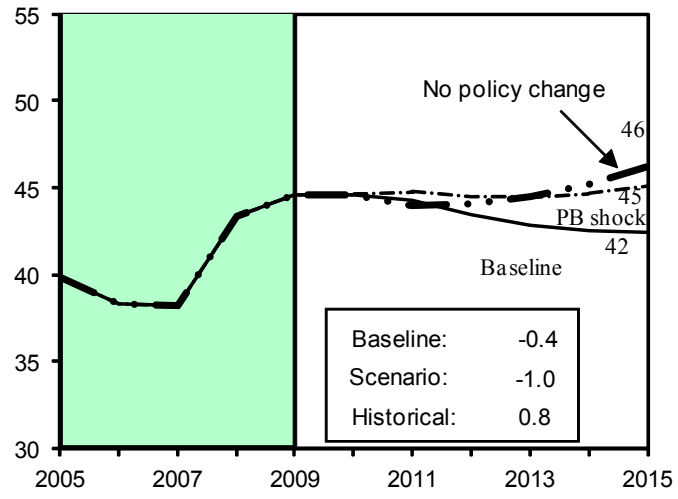

Real depreciation and contingent liabilities shocks $3 /$

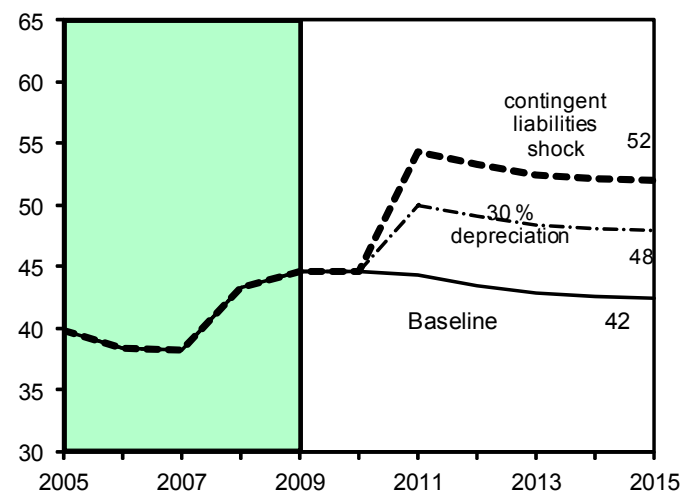

Sources: International Monetary Fund, country desk data, and staff estimates.

1/ Shaded areas represent actual data. Individual shocks are permanent one-half standard deviation shocks. Figures in the boxes represent average projections for the respective variables in the baseline and scenario being presented. Ten-year historical average for the variable is also shown.

2/ Permanent $1 / 4$ standard deviation shocks applied to real interest rate, growth rate, and primary balance.

$3 /$ One-time real depreciation of 30 percent and 10 percent of GDP shock to contingent liabilities occur in 2010, with real depreciation defined as nominal depreciation (measured by percentage fall in dollar value of local currency) minus domestic inflation (based on GDP deflator). 


\section{However, pressures on bank capital from credit risk could yet arise as NPLs have}

drifted up and corporate sector buffers have been reduced. The credit slowdown continues, and has spread beyond consumer finance. At the same time, gross NPLs have risen gradually, reaching some 3 percent of total loans by end-2009. Strong pre-crisis corporate sector cash buffers likewise have been drawn down some, while internal cash flow generation has been adversely affected by the downturn. Analytical work by the team suggests that were the recovery to be more sluggish than envisaged over the next year, corporate distress could rise. Nonetheless,

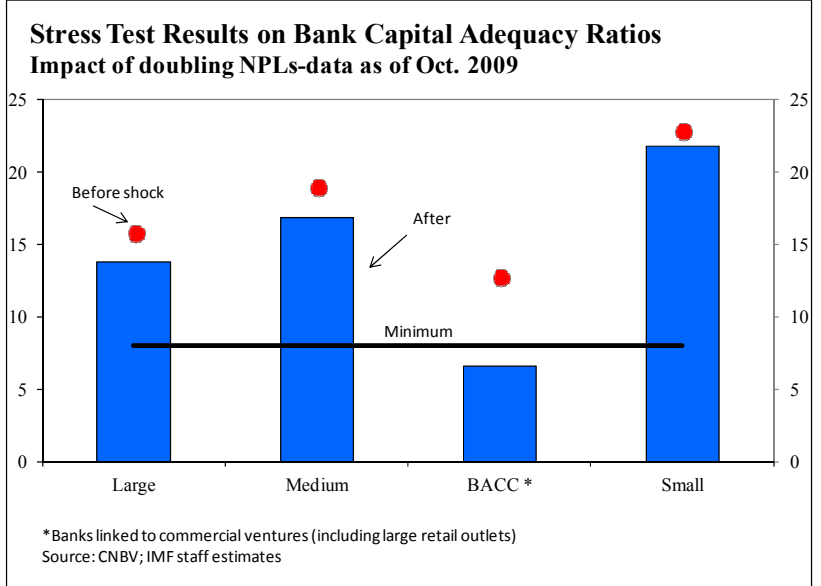
the team's stress scenarios (Text Figure) show that most banks would be well placed to manage a further rise in NPLs, though some groups could come under greater pressure.

29. Smaller non-bank intermediaries are at greater risk. The Sofoles/Sofomes sector, (comprising at least 3 percent of system assets) ${ }^{9}$ relied heavily on domestic wholesale financing. With the market disruptions after the Lehman bankruptcy, the sector experienced severe liquidity pressures in late 2008 , leading to liquidity facilities being made available by the public sector, and to the intervention of some larger intermediaries. Looking ahead, the sector faces important downsides from credit risk. The authorities are planning to widen the regulatory perimeter to better monitor these entities (see $\$ 33$ ) and also intend to gather more information about the size of these institutions, their financial soundness, and their linkages to the rest of the financial system.

\footnotetext{
${ }^{9}$ Sofoles and Sofomes are non-bank financial institutions created in the early 1990 s with the aim at providing credit and financing to specific sectors of the economy. Since 2006, their mandate was expanded to allow for leasing and factoring, and extending credit to multiple sectors of the economy. Discussions during the mission indicate that the number of active entities is larger than those currently regulated, though many of these could on average be smaller in size than those in the regulated group. The authorities are stepping up monitoring of the sector.
} 


\section{Rethinking the financial sector framework}

30. Changes to international financial system regulations proposed by the FSB are not likely to have a large direct impact on banks in Mexico. As discussed in Box 4, capital requirements and definitions are proposed to be made more stringent, liquidity requirements enhanced, and the reach of regulators increased. But the direct impact on Mexican banks will be muted as they already meet the higher standards - capital is good quality, trading and securitized operations are small, and liquidity is already high. Furthermore, emerging markets have much to gain from greater cross-border coordination of bank monitoring and resolution, as highlighted by the current crisis where financial sector shocks emanated from abroad in many cases.

31. However, these reforms are likely to increase expenses for global bank parents, which could in part be passed through to operations in Mexico. In common with other emerging markets, Mexico has a substantial participation of foreign banks (Text Figure). Indeed, about 80 percent of system assets in Mexico are owned by systemically important global banks that are likely to face higher capital charges from their home country regulators as a result of the changes discussed above. The authorities shared the concerns about possible pass-through of higher capital charges, but noted that it was early to say what the full impact of these changes would

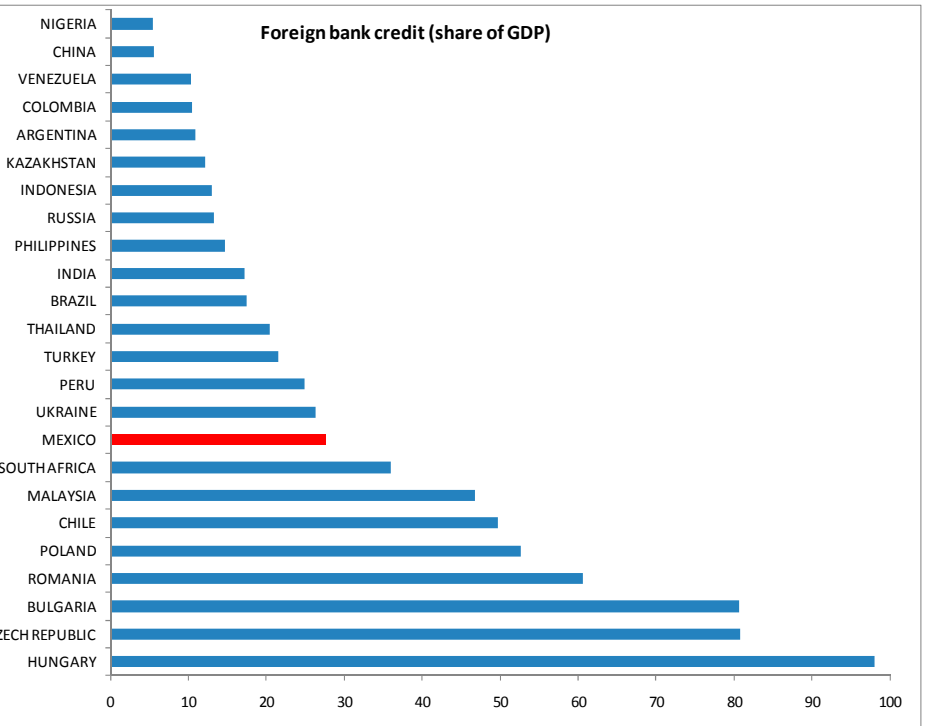
be. Nonetheless, to manage risks with regards to global banks, the authorities are considering tightening the limit for exposure of Mexican subsidiaries to their foreign parent banks from 50 percent of equity to 20 percent.

\section{Further developing the framework for supervision of systemic risk will also be} important. Significant strides have been made in strengthening the institutional framework for financial oversight in Mexico. But the crisis has brought to the fore the importance of monitoring systemic risk. As a first step, the authorities are considering establishing a committee comprising the Ministry of Finance, Banxico, the Banking Commission and other agencies to coordinate actions in cases of systemic importance. In addition, the new bankruptcy law for financial institutions - with important improvements to the frameworkis awaiting approval in Congress. 


\section{Box 4. Directions in Global Regulatory Reform-Direct Implications for Mexico}

Definition of capital. Given concerns over the quality of especially Tier-1 capital, stricter international standards are being developed which will require global banks to raise common equity and loss-absorbing Tier-2 capital. However Mexican banks have high capital ratios, mostly comprising Tier-1 capital, which in turn is mostly common equity. ${ }^{1}$ Proposals to introduce a minimum capital charge on banks' trading books should also have limited impact in Mexico given the relatively small proprietary position of most banks. However, potential revisions to Tier 2 capital standards could require capital to be raised by some banks.

Systemic Risk Requirements. Specific capital charges on large banks related to TBTF concerns would likely raise capital requirements on some banks in Mexico and in Latin America, given that banking systems in the region are relatively concentrated.

Liquidity Requirements. Many Latin American countries, including Mexico, ${ }^{2}$ have liquidity requirements that are higher than in most advanced countries. As such, the adoption of tighter standards being proposed - such as a "liquidity coverage ratio" for a 30-day horizon, or a "net stable funding ratio" with a medium term perspective-would likely have a moderate impact in most countries in the region, including Mexico. Countries where wholesale funding is important may be more adversely affected.

Dynamic provisions. Mexican banks, in common with most others in Latin America, have provisions in excess of non-performing loans (the ratio is 150 percent as of June 2009). As such, were systems of dynamic provisions to be introduced going forward, these would not materially affect banks in the near term, but would moderate balance sheet expansion during cyclical upswings.

Dynamic capital. Proposals here aim at smoothing the impact of economic fluctuations on bank capital. This could be done by introducing a countercyclical scaling factor to capital ratios, which would be linked to the long-term behavior of, for example, GDP. The objective would be to build buffers in good times and avoid excessive deleveraging in bad times. This would likely not have much near term impact, but would require capital bases to be built up faster as the recovery takes hold.

Regulatory perimeter. Proposals here seek to broaden the regulatory net, especially given the experience with risk hidden off bank's balance sheets in advanced countries. Mexico, in common with others in the region, already has in place a broad perimeter. But there are still systemic institutions in some countries that are arguably insufficiently regulated and supervised, including cooperatives, insurance companies and offshore financial institutions. In Mexico, the authorities are considering regulating more closely the nonbank sector (Sofoles/Sofomes).

Cross-Border Issues. Key issues under consideration include the introduction of "living wills", and arrangements for potential loss sharing. Given the strong international links of financial systems in Mexico and much of Latin America, existing MOU's with home regulators of global banks may require steps to further clarify the responsibilities of each party in case of failure of subsidiaries or parent bank. Mexican authorities are also considering reducing the limit of exposure of subsidiaries of foreign banks with parent institutions from 50 percent of equity to 20 percent.

As of end-June 2009, the capital adequacy ratio of the banking system stood at 15.2 percent and the Tier I capital adequacy ratio at 13.8 percent.

${ }^{2}$ As of end-July 2009, the liquidity ratio of liquid assets to short term liabilities of the banking sector (less than 30 days) stands at about 190 percent. However, this ratio has not been calculated under the more stringent assumptions set by the Basel Committee.

Prepared by Jose Giancarlo Gasha. 


\section{The authorities are planning to tighten regulation of non-banks that could}

represent significant risk, while preserving the current lighter regulation for other smaller intermediaries that has been successful in deepening the financial system. ${ }^{10}$ The team advised broadening the criteria for being subject to regulation ${ }^{11}$ and requiring full information disclosure by all non-banks which represent material risks. ${ }^{12}$ The Sofoles strategy ought also to focus on diversifying the funding base, improving origination standards, addressing governance issues, and reducing conflicts of interest with developers. The authorities are mindful of striking a balance between containing systemic risk and allowing development of this sector which provides intermediation services to under-financed groups. But there was agreement on the importance of collecting more information on the sector.

\section{Reinvigorating medium-term growth}

34. A wide range of factors, including low investment and productivity rates, have constrained growth in Mexico. As documented extensively in Chiquiar and Ramos Francia (2009), the concerns range from rigid and non-competitive markets, to institutional structures that may incentivize rent-seeking activities. Both productivity growth and investment in Mexico (as well as in Latin America) have remained lower than developing country averages. The illustrative scenario in the Text Figure shows the substantial increases in investment and/or productivity needed to double Mexico's percapita GDP over the next two decades. An

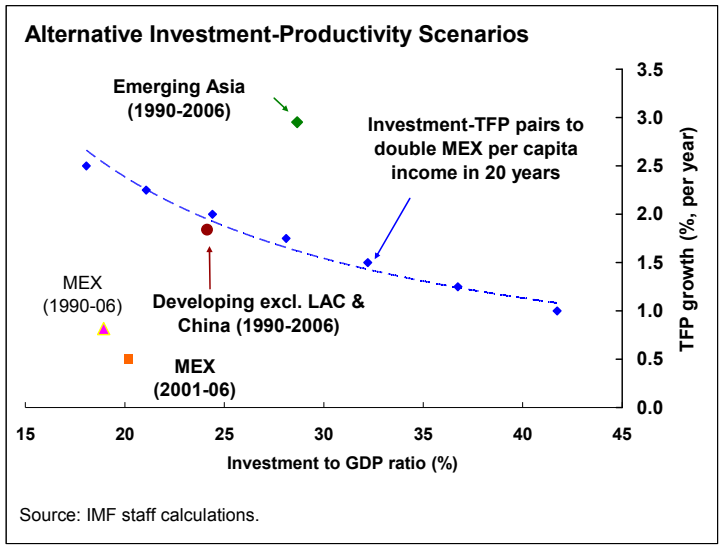
obstacle to higher private investment is enforcement of contract rights. Mexico lags its peers with respect to the cost of enforcing contracts, which are over $1 \frac{1 / 2}{2}$ the OECD median, exceeding those in most emerging markets. The authorities noted that they had launched an initiative to significantly streamline regulations which should gradually lead to improvements in cost of doing business indicators.

\footnotetext{
${ }^{10}$ A draft law presented at the Mexican Senate will now also regulate Sofoles/Sofomes that have equity links to some other types of non-banks, or that seek funding in capital markets. Fit and proper tests will also be tightened, while the CNBV will be given greater enforcement powers.

${ }^{11}$ In line with international practices, the authorities are considering subjecting to regulation and supervision non-bank institutions of significant size.

${ }^{12}$ For example, providing financial statements, financial soundness indicators, at least quarterly, and establishing "subsidiary" supervision for the universe of Sofoles/Sofomes that remains "unregulated" (for example, reporting financial information to the industry association (Amfe)).
} 
35. Boosting competition is key to achieving higher productivity growth. The team's analysis of firm-level data from Mexico's manufacturing sector shows that as concentration increases (measured by a rising Lerner Index of mark-ups) past a certain point, productivity growth is seen to decline sharply (Text Figure).$^{13}$ As such, it will be crucial also to strengthen competition (especially in telecoms which has been shown to have very large net work effects), by reducing barriers to entry. Furthermore, reducing product market regulation, especially in key network sectors such as

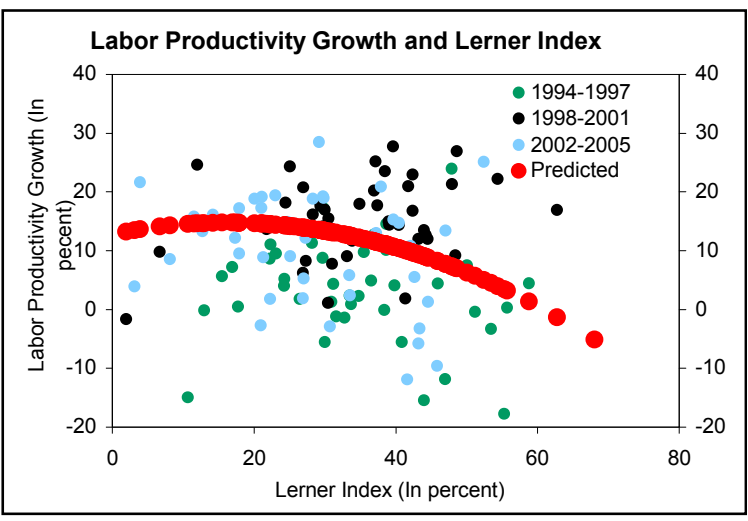
electricity, gas and water would boost productivity. ${ }^{14}$ The authorities believe that recent reforms in the energy sector could be an important step here in supporting productivity growth going forward. ${ }^{15}$

\section{Another symptom of structural impediments holding back flexibility and growth in} Mexico is the high level of labor market informality (see Chapter II of the SIPs). Sixty percent of the labor force is employed in the informal sector. Moreover, wages in the formal sector are about 15 percent higher than in the informal sector after controlling for observable differences in worker characteristics such as age and educational level. Using this "wage gap" as a proxy for productivity and the historical average size of the informal sector, an illustrative calculation suggests that informality could be costing the Mexican economy as much as 9 percent of GDP. ${ }^{16}$ Moreover, while more productive sectors (as proxied by having a higher wage-gap) are relatively more formal, reducing their still

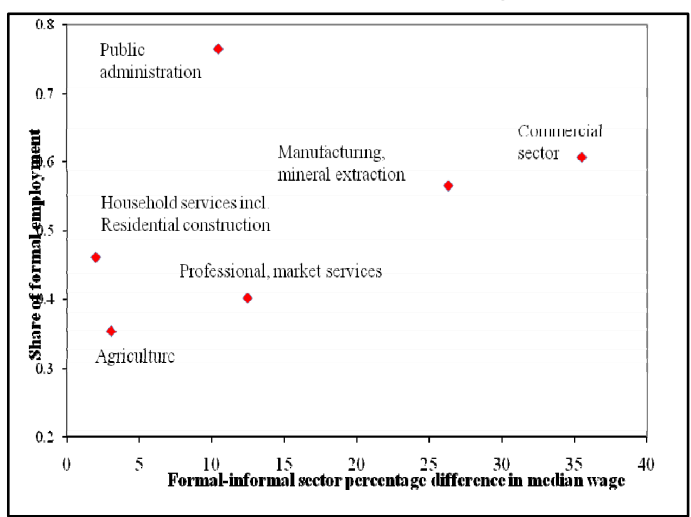
high levels of informality could yield

\footnotetext{
${ }^{13}$ Tulin, Garcia-Saltos, and Leyva Parra, mimeo (2008).

${ }^{14}$ OECD (2009) reports that the cost of Mexican regulations in these sectors is four times the OECD median.

${ }^{15}$ The authorities have restructured Mexico's largest power distribution utility, responsible for most major urban/industrial centers to allow convergence to the higher levels of efficiency seen in the rest of the public sector.

${ }^{16}$ This figure is likely an upper bound. Details of the computation and associated caveats are presented in Chapter II of the SIP.
} 
substantial growth dividends. The authorities have been developing a social consensus on labor reforms that should lead to some increases in flexibility. However, further steps to better align incentives, including with respect to social insurance, will likely be needed to have a substantial impact on informality.

\section{International reserve levels}

\section{During the crisis, investors expressed concerns regarding available reserves in}

Mexico. Reserve cover in Mexico is in line with several rules of thumb and compares favorably with emerging market peers in a number of dimensions. Nonetheless, the authorities noted that adverse market reaction towards Mexico in early 2009 focused on the perception of low reserve cover against possible external drains, including those related to a possible reversal of capital flows. Indeed, they considered reserve cover relative to balance sheet indicators to be a more relevant metric. As shown in the Text Figure and Box 5, Mexico's reserve ratios against balance sheet indicators (such as investment

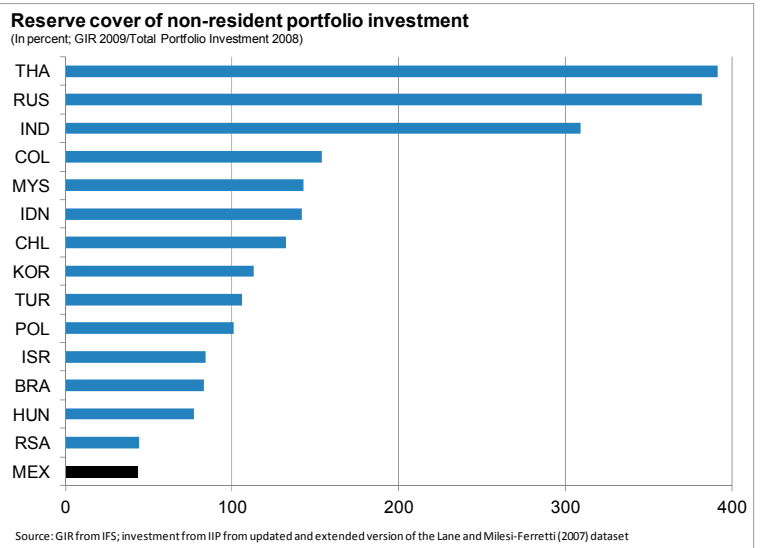
positions of non-residents and financial depth) were well below those in other emerging markets. In this context, insurance against tail risks associated with the external outlook was provided by the swap line with the Fed and the FCL from the Fund (amounting to about US\$80 billion in total).

\section{Looking forward, the authorities indicated that they intended to increase the level} of reserves over the coming years. They would accomplish this by a combination of retaining public sector foreign exchange receipts and rules-based intervention mechanisms consistent with maintaining the freely floating exchange rate regime. ${ }^{17}$ The team agreed that there was a case for higher external insurance (see Box 5 for a further discussion of related considerations), but noted that the authorities' strategy should leave open possibilities for multilateral insurance. The authorities noted that were the Fund to develop suitable alternative insurance mechanisms for members with strong fundamentals, that this would be a serious option for countries to consider. As such, they noted that forthcoming reforms of Fund facilities could play a role in their decision regarding options for increasing external insurance in the period ahead.

\footnotetext{
${ }^{17}$ Subsequent to the mission, the authorities have implemented a mechanism that had previously been in place during 19962001. Under this mechanism, each month Banxico sells a preannounced amount of put options to financial intermediaries, who have the right to exercise the options - selling dollars to Banxico for pesos - at a price determined by the market, subject to a pre-agreed knock-in condition. The condition, specifying that the intermediaries could sell dollars to Banxico only if the peso was more appreciated than the 20-day moving average, has helped reduce the volatility of the exercise price. For a more detailed discussion of the mechanism, see Sidaoui, 2003, "Policies for international reserve accumulation under a floating exchange rate regime: the experience of Mexico (1995-2003)," http://www.bis.org/publ/bppdf/bispap23r.pdf , pp. $220-1$.
} 


\section{Box 5. Mexico: Reserve Adequacy}

Market concerns arose regarding the level of reserves in Mexico during the global crisis. Ahead of the crisis, Mexico's reserves were seen as adequate for "normal times," conforming to various rules of thumb on flow variables — indeed, this remains the case - including with respect to coverage of maturing debt (see Text Box). However reserve cover relative to various balance sheet indicators is lower, including relative to broad money, a proxy for possible capital flight, and relative to portfolio investment which captures part of the exposure to withdrawal from liquid Mexican assets by nonresidents investors. Underscoring the importance of reserves, in a broader EM context, the team's analysis shows that, even over a longer period, changes in reserve cover has a significant relationship with changes in risk measures (CDS and EMBI spreads), including when variables

\begin{tabular}{|c|c|c|c|c|}
\hline \multicolumn{5}{|c|}{ Mexico. Comparisons under various reserve adequacy metrics at end-2009 } \\
\hline & Mexico & $\begin{array}{r}\text { Lat Am } \\
\text { EM } \\
\text { Median }\end{array}$ & $\begin{array}{l}\text { Mexico at } \\
\text { Median 1/ }\end{array}$ & Difference 2 \\
\hline Reserves to imports $3 /$ & 4 & 6 & 146 & \\
\hline Reserves to broad money 4/ & 18 & 34 & 184 & 84 \\
\hline Reserves to GDP & 11 & 13 & 114 & 14 \\
\hline Reserves to external financing needs $5 /$ & 163 & 149 & 91 & -9 \\
\hline Reserves to portfolio investment $6 /$ & 88 & 139 & 157 & 57 \\
\hline $\begin{array}{l}\text { 2/ Difference between (4) and the } 2009 \\
3 / \text { In months of imports } \\
4 / \text { In percent. } \\
5 \text { / Short-term debt at residual maturity } \\
\text { 6/ Reserves at end-2009 to portfolio inv } \\
\text { in Latin America. }\end{array}$ & $\begin{array}{l}\text { urrent aco } \\
\text { ent at end }\end{array}$ & unt defi & US\$ 100 & tal markets \\
\hline
\end{tabular}
controlling for macroeconomic fundamentals — such as external and public deficits and debt—are included.

The remainder of this box considers approaches to thinking about the appropriate level of reserves. Empirical analysis for reserve demand provides a wide range of estimates.

- Much of the literature has analyzed reserve adequacy based on a variant of the "buffer-stock model," whereby reserves are seen as resources to smooth consumption to mitigate the impact (if not the incidence) of sudden stops of foreign exchange. Early efforts_-Edwards (1983) and Flood and Marion (2002), for instance - found support for the hypothesis that adjustment costs and opportunity cost of reserves adversely affect reserve accumulation, while GDP and reserve volatility work in the other direction. Using such a specification for a sample of emerging marketsbut adjusting for Asian countriesshows Mexico's reserves to be close to predicted levels. After the Asian crisis, with the increase in the perceived

\begin{tabular}{lrr} 
& $\begin{array}{c}\text { Fitted Value } \\
\text { (1) }\end{array}$ & $\begin{array}{r}\text { Difference 1/ } \\
\text { (2) }\end{array}$ \\
\hline Baseline 2/ & 105 & 5 \\
Adding: financial depth 3/ & 125 & 25 \\
Adding : external vulnerability indicators 4/ & 129 & 29 \\
\hline
\end{tabular}

$1 /$ The difference between (1) and the level of reserves for Mexico for 2009 2/ Reserve demand regression with population, openness, exchange rate flexibility, and income as explanatory variables.

3/ Adds to $2 /$ financial depth measure (M2/GDP) and crisis dummies. 4/ Adds to 3/ debt-to-GDP ratio and FDI-to-GDP ratio. probability of sudden stops, reserve accumulation increased.

- $\quad$ Aizenman and Lee (2002) and Obstfeld et al. (2009) are among those that attempt to explain the post-crisis behavior. The studies find that insurance against capital account vulnerabilities explains much of the buildup in recent years. Obstfeld et al. (2009) posit a role for "financial depth" (broad money to GDP ratio) representing the probability of deposit outflows by residents. Using such specifications controlling for balance sheet factors, and additional external vulnerability indicators, suggest larger differences of fitted versus actual reserve holdings at end-2009 (see Text Figure).

- However, it is also worth noting that these regressions do not imply "optimality," focusing instead on deviations from conditioned means across the sample. Nonetheless, changing relevant parameters in models of "optimal" levels of reserves — such as that developed by Jeanne and Rancière (2007) also yields intuitive results: relatively small increases in parameters such as risk aversion (a likely outcome following a global crisis) or an increase in the probability of a sudden stop can lead to substantial increases in the optimal level of reserves.

Prepared by Bikas Joshi. 


\section{Staff Appraisal}

39. Mexico's strong balance sheets and very strong policy frameworks have cushioned the blow from the global crisis. The investments of the last decade in lowering public debt and introducing rules-based policy frameworks have paid dividends by preserving stability and enabling a counter-cyclical policy response for the first time in many years. Moreover, the lower leverage and stronger liquidity and income positions of banks and corporates have allowed the private sector to absorb the initial shock without substantially weakening balance sheets.

40. Despite a very strong and effective policy response, the Mexican economy has experienced a sizable shock and risk perceptions have weakened somewhat during the crisis. In part, this reflected renewed concerns about medium term growth and fiscal prospects - reflecting rapid declines in oil production - as well as investors' perception that Mexico's reserves were below those in emerging market peers. Thus, a key challenge - on which the authorities have already taken important steps - is to address these medium to long term concerns.

41. The near term growth outlook is favorable though risks are to the downside in 2011. A cyclical recovery is already in train, and the team expects growth of about 4 percent in 2010. With the output gap still large, growth is expected to be above potential for the next several years. An important concern going forward are the continued uncertainties regarding the global economic and financial outlook which create downside risks in 2011. Spillovers from these will require continued close monitoring and add to the imperatives to rebuild buffers.

42. The tax reform included in the 2010 budget is a welcome step in assuring fiscal sustainability. It is a testament to the authorities' commitment to sound policies that they were able to build consensus for these measures in the midst of a sharp slowdown. The budget has been carefully calibrated to smooth as much as feasible the withdrawal of stimulus while maintaining funding for crucial social and investment programs.

43. Currently supportive monetary policy settings are appropriate. With fiscal policy turning contractionary at a time when output remains well below potential, the burden of supporting demand shifts to monetary policy. With inflation expectations remaining wellbehaved so far, Banxico has some room for maneuver. Indeed, Banxico has effectively communicated the one-off nature and estimated size of the impact of changes in tax rates and administered prices on inflation. Nevertheless, risks of second round effects naturally remain a concern to be watched.

44. The flexible exchange rate has also played an important role in the adjustment process. The crisis has seen a substantial depreciation of the peso, which has facilitated adjustment in goods and asset markets. The exchange rate appears broadly fair-valued at the current juncture based on the array of methodologies applied by the team. The authorities' 
intervention in foreign exchange markets has focused on maintaining orderly liquidity conditions, and the rules based mechanisms used have preserved the most essential aspects of the flexible exchange rate system.

\section{Reforms over the last three years have strengthened the fiscal position, although} with the share of oil revenues expected to gradually decline and current spending pressures likely to mount, additional measures will be needed over the medium term. The authorities' near-term focus on finding expenditure savings and improving tax administration is commendable. Effective implementation of the oil sector reform will also be key, and progress should be reviewed at an early date. Looking forward, additional steps to address structural weaknesses in the tax system, especially the narrowness of the tax base, will be important. Introducing a medium term expenditure planning framework would also help.

46. The balanced budget rule has been a key anchor, but there is a case for moving towards a structural rule over time. The current rule has built up the credibility of the fiscal framework. But moving to a structural rule would lower procyclicality and reduce the asymmetry inherent in the current framework. Such a rule should also be designed to be consistent with a continued reduction in debt levels to pre-crisis levels. The elimination of the caps on savings in stabilization funds for this year is a welcome step - it would be useful to consider making this permanent.

47. The financial stability outlook is favorable, though some risks remain. Still falling credit combined with reduced corporate buffers and possible downside risks to growth could yet lead to a further weakening in credit quality. However, most banks are well capitalized and are well placed to absorb additional shocks. The nonbank sector has been hit harder by the crisis and it will be important to step up monitoring of these institutions to get a better picture of risks that might arise. While financial system regulation and supervision are already very strong, the authorities' proposals to broaden the regulatory perimeter, set up a committee for assessing systemic risks, and reform the resolution framework for the financial system are appropriate.

\section{Global banks could be a conduit for tighter financing conditions arising from}

proposed international regulatory reforms. At this time, it is not expected that the regulatory proposals put forward by the FSB would have significant direct impact on Mexican banks. However, other steps to place restrictions on the operations of banks in advanced countries could lead to disintermediation in emerging markets such as Mexico. Moreover, to the extent that global banks may face higher capital charges going forward, some transmission of higher costs to emerging markets such as Mexico is possible. In this context, the authorities' proposals to strengthen regulations against liquidity drains from domestic banks and strengthen coordination with home country supervisors of global banks are reasonable. Planned steps to develop further capital markets to create alternate sources of funding beyond the largely foreign-owned banking system are also welcome. 
49. A central challenge is to boost potential growth and advancing on structural reforms to boost competition and flexibility. Substantial increases in investment and productivity will be needed to substantially speed up growth. The recent important steps to improve productivity in the electricity sector will lower costs and support growth and employment. The authorities' intent to further bolster the competition framework in Mexico is timely, and rapid action on high profile cases in key network industries would send positive signals. Meanwhile, labor market reforms being discussed go in the right direction, but more action will be needed to increase flexibility.

50. An increase in reserves is desirable, but it will be important to keep open the option of using multilateral insurance mechanisms. Risk perceptions have changed in the wake of the crisis. Attention has especially been drawn to Mexico's lower coverage compared to peers on measures related to balance sheet exposures. In this context, the authorities' indication that they would be prepared to consider multilateral insurance mechanisms to achieve their goals, should suitably strong instruments emerge from the current review of Fund facilities, is welcome.

51. It is recommended that the next Article IV consultation with Mexico occur on the standard 12-month cycle. 
Table 1. Mexico: Selected Economic, Financial, and Social Indicators, 2005-2011

GDP per capita (U.S. dollars, 2007)

Population (millions, 2007)

Life expectancy at birth (years, 2006)

Under 5 mortality rate (per thousand, 2006)

I. Social and Demographic Indicators

9,693 Households below the poverty line (percent, 2002)

105.8 Income share of highest 20 percent/low est 20 percent 12.8

74.5 Adult illiteracy rate (2005)

35.3 Gross primary education enrollment rate (2006) 112.7

II. Economic Indicators

\begin{tabular}{|c|c|c|c|c|c|c|c|}
\hline & 2005 & 2006 & 2007 & 2008 & $\begin{array}{l}\text { Prel. } \\
2009\end{array}$ & $\begin{array}{r}\text { Proj. } \\
2010\end{array}$ & $\begin{array}{r}\text { Proj. } \\
2011\end{array}$ \\
\hline \multicolumn{8}{|c|}{ (Annual percentage change, unless otherw ise indicated) } \\
\hline \multicolumn{8}{|l|}{ National accounts in constant prices } \\
\hline Real GDP & 3.2 & 4.9 & 3.3 & 1.5 & -6.5 & 4.0 & 4.5 \\
\hline Net exports (contribution) & -0.6 & -0.7 & -0.6 & -1.0 & 1.3 & -0.5 & -0.2 \\
\hline Total domestic demand & 3.7 & 5.7 & 3.8 & 2.3 & -7.8 & 4.6 & 4.6 \\
\hline Private consumption & 4.8 & 5.7 & 3.9 & 1.5 & -5.8 & 6.6 & 4.6 \\
\hline Public consumption & 2.4 & 1.7 & 2.1 & 0.6 & 2.4 & -1.8 & 3.7 \\
\hline Gross fixed investment & 7.5 & 9.8 & 7.2 & 4.9 & -12.5 & -1.5 & 3.2 \\
\hline Change in business inventories (contribution) & -1.2 & -0.3 & -0.5 & 0.1 & -1.4 & 0.7 & 0.4 \\
\hline \multicolumn{8}{|l|}{ External sector } \\
\hline Exports, f.o.b. & 14.0 & 16.7 & 8.8 & 7.2 & -21.2 & 19.6 & 7.6 \\
\hline Export volume & 5.3 & 8.5 & 3.5 & -2.4 & -11.2 & 10.4 & 4.7 \\
\hline Imports, f.o.b. & 12.7 & 15.4 & 10.1 & 9.5 & -24.0 & 12.1 & 8.8 \\
\hline Import volume & 7.3 & 10.4 & 4.4 & 1.0 & -18.2 & 3.2 & 3.7 \\
\hline Petroleum exports (percent of total exports) & 14.9 & 15.6 & 15.8 & 17.4 & 13.4 & 12.4 & 12.1 \\
\hline Terms of trade (deterioration -) & 3.0 & 2.9 & -0.3 & 1.3 & -11.3 & 0.4 & -0.4 \\
\hline \multicolumn{8}{|l|}{$\begin{array}{l}\text { Exchange rates } \\
\text { Nominal exchange rate (US\$/Mex\$) }\end{array}$} \\
\hline (average, depreciation -) & 3.4 & 0.0 & -0.3 & -1.8 & -21.4 & $\ldots$ & $\ldots$ \\
\hline Real effective exchange rate (CPI based) & & & & & & & \\
\hline (average, depreciation -) & 4.1 & 0.5 & -0.1 & -0.7 & -12.9 & $\ldots$ & $\ldots$ \\
\hline \multicolumn{8}{|l|}{ Employment and inflation } \\
\hline Consumer prices (end of year) & 3.3 & 4.1 & 3.8 & 6.5 & 3.6 & 5.3 & 3.0 \\
\hline Formal sector employment (annual average) & 3.2 & 4.7 & 4.2 & 2.1 & -3.1 & $\ldots$ & $\ldots$ \\
\hline Formal sector unemployment rate (annual average) & 3.6 & 3.6 & 3.7 & 4.0 & 5.5 & 5.0 & 4.5 \\
\hline Real manufacturing w ages (annual average) & -0.2 & 0.4 & 1.0 & 0.9 & $\ldots$ & $\ldots$ & $\ldots$ \\
\hline \multicolumn{8}{|l|}{ Money and credit } \\
\hline Broad money (M4a) & 15.0 & 12.8 & 11.5 & 17.2 & 5.9 & 6.7 & 9.8 \\
\hline Treasury bill rate (28-day cetes, in percent, annual average) & 9.2 & 7.2 & 7.2 & 7.6 & 5.4 & $\ldots$ & $\ldots$ \\
\hline \multicolumn{8}{|c|}{ (In percent of GDP) } \\
\hline \multicolumn{8}{|l|}{ Nonfinancial public sector } \\
\hline Augmented balance $1 /$ & -1.4 & -1.0 & -1.4 & -1.5 & -4.7 & -3.4 & -3.0 \\
\hline Augmented primary balance & 1.5 & 1.8 & 1.3 & 1.1 & -2.0 & -1.6 & -0.9 \\
\hline Traditional balance $2 /$ & -0.1 & 0.1 & 0.0 & -0.1 & -2.3 & -2.7 & -2.3 \\
\hline Gross public sector debt & 39.8 & 38.3 & 38.2 & 43.3 & 44.6 & 44.6 & 44.2 \\
\hline Net public sector debt & 35.2 & 32.4 & 31.4 & 35.8 & 38.8 & 39.1 & 39.0 \\
\hline \multicolumn{8}{|l|}{ Savings and investment } \\
\hline Gross domestic investment & 24.4 & 26.1 & 25.8 & 26.4 & 22.1 & 21.9 & 22.5 \\
\hline Public investment & 4.6 & 4.3 & 4.7 & 5.5 & 5.8 & 5.0 & 4.4 \\
\hline Private investment & 15.6 & 16.5 & 16.7 & 16.6 & 15.7 & 14.9 & 15.3 \\
\hline Change in inventories & 4.2 & 5.3 & 4.5 & 4.2 & 0.6 & 1.9 & 2.8 \\
\hline Gross national saving & 23.8 & 25.7 & 25.0 & 24.9 & 21.4 & 20.4 & 20.9 \\
\hline Public saving $3 /$ & 3.2 & 3.7 & 3.3 & 3.7 & 0.6 & 1.1 & 0.9 \\
\hline Private saving & 20.6 & 22.0 & 21.7 & 21.2 & 20.7 & 19.2 & 20.0 \\
\hline External current account balance & -0.5 & -0.5 & -0.8 & -1.5 & -0.6 & -1.4 & -1.5 \\
\hline Non-oil external current account balance & -2.3 & -2.5 & -2.7 & -3.0 & -1.9 & -2.0 & -1.5 \\
\hline Net foreign direct investment & 1.9 & 1.5 & 2.7 & 2.1 & 1.3 & 2.3 & 2.2 \\
\hline \multicolumn{8}{|c|}{ (In percent of exports of goods, nonfactor services, and transfers) } \\
\hline Public external debt service 4/ & 9.4 & 14.3 & 7.5 & 6.8 & 8.8 & 7.3 & 8.1 \\
\hline \multicolumn{8}{|c|}{ (In billions of U.S. dollars, unless otherw ise indicated) } \\
\hline Net international reserves & 68.7 & 67.7 & 78.0 & 85.4 & 90.8 & 105.8 & 120.8 \\
\hline Gross official reserves in percent of short-term debt $5 /$ & 111.4 & 147.7 & 153.9 & 165.9 & 208.2 & 209.1 & 187.5 \\
\hline Gross external debt (in percent of GDP, end of period) & 20.4 & 17.8 & 18.8 & 18.5 & 23.8 & 22.7 & 22.9 \\
\hline Crude oil export price, Mexican mix (US\$/bbl) & 42.8 & 53.1 & 61.7 & 84.4 & 57.8 & 70.8 & 74.8 \\
\hline
\end{tabular}

Sources: National Institute of Statistics and Geography; Bank of Mexico; Secretariat of Finance and Public Credit; and IMF staff estimates.

1/ Public Sector Borrow ing Requirements excl. nonrecurrent revenue.

$2 /$ The break in the series in 2009 is due to definitional and accounting changes.

$3 /$ Estimated as as the difference betw een the augmented fiscal balance, as reported by SHCP, and public investment, as reported in the national accounts. 4/ Debt service on gross external debt of the tederal government, development banks and nont inanical public enterprises (adjusted tor Hidiregas).

$5 /$ In percent of short-term debt by residual maturity. Historical data include all prepayments. 
Table 2. Mexico: Financial Operations of the Public Sector, 2005-2015

(In percent of GDP)

\begin{tabular}{|c|c|c|c|c|c|c|c|c|c|c|c|c|}
\hline & \multirow[t]{2}{*}{2005} & \multirow[t]{2}{*}{2006} & \multirow[t]{2}{*}{2007} & \multirow[t]{2}{*}{2008} & \multirow[t]{2}{*}{2009} & \multicolumn{2}{|c|}{2010} & \multirow{2}{*}{$\begin{array}{r}2011 \\
\text { Proj. }\end{array}$} & \multirow{2}{*}{$\begin{array}{r}2012 \\
\text { Proj. }\end{array}$} & \multirow{2}{*}{$\begin{array}{c}2013 \\
\text { Proj. }\end{array}$} & \multirow{2}{*}{$\begin{array}{r}2014 \\
\text { Proj. }\end{array}$} & \multirow{2}{*}{$\begin{array}{l}2015 \\
\text { Proj. }\end{array}$} \\
\hline & & & & & & Budget & Proj. & & & & & \\
\hline Budgetary revenue, by type & 21.1 & 21.8 & 22.2 & 23.6 & 23.6 & 21.9 & 22.0 & 21.8 & 21.7 & 21.6 & 21.3 & 21.1 \\
\hline Oil revenue & 7.9 & 8.3 & 7.9 & 8.7 & 7.9 & 7.1 & 7.0 & 6.7 & 6.5 & 6.4 & 6.3 & 6.2 \\
\hline Non-oil tax revenue $1 /$ & 8.6 & 9.0 & 9.3 & 10.0 & 9.4 & 10.3 & 10.4 & 10.7 & 10.9 & 10.9 & 10.7 & 10.6 \\
\hline Non-oil non-tax revenue & 4.6 & 4.5 & 5.0 & 4.9 & 6.3 & 4.4 & 4.5 & 4.3 & 4.3 & 4.3 & 4.3 & 4.3 \\
\hline \multicolumn{13}{|l|}{ Budgetary revenue, by entity } \\
\hline Federal government revenue & 15.3 & 15.0 & 15.3 & 16.9 & 16.8 & 15.6 & 15.0 & 14.9 & 14.9 & 14.8 & 14.5 & 14.4 \\
\hline Tax revenue, of which: & 8.8 & 8.6 & 8.9 & 8.2 & 9.5 & 10.2 & 10.6 & 10.9 & 11.2 & 11.2 & 11.2 & 11.1 \\
\hline excises (including fuel) & 0.5 & -0.1 & -0.1 & -1.4 & 0.4 & 0.4 & 0.7 & 0.7 & 0.7 & 0.8 & 0.9 & 0.9 \\
\hline Nontax revenue & 6.5 & 6.4 & 6.3 & 8.7 & 7.3 & 5.3 & 4.4 & 4.0 & 3.7 & 3.6 & 3.4 & 3.3 \\
\hline Public enterprises & 5.8 & 6.8 & 6.9 & 6.7 & 6.8 & 6.3 & 7.0 & 6.9 & 6.8 & 6.8 & 6.8 & 6.8 \\
\hline PEMEX & 2.0 & 3.1 & 3.3 & 3.0 & 3.2 & 2.8 & 3.6 & 3.5 & 3.4 & 3.4 & 3.3 & 3.3 \\
\hline Other & 3.8 & 3.7 & 3.6 & 3.7 & 3.7 & 3.5 & 3.4 & 3.4 & 3.4 & 3.4 & 3.4 & 3.4 \\
\hline Budgetary expenditure & 21.2 & 21.7 & 22.2 & 23.7 & 25.9 & 24.6 & 24.7 & 24.0 & 23.7 & 23.6 & 23.3 & 23.1 \\
\hline Primary & 18.9 & 19.3 & 20.0 & 21.8 & 23.7 & 22.3 & 22.4 & 21.7 & 21.3 & 21.1 & 20.8 & 20.5 \\
\hline Programmable & 15.8 & 16.0 & 16.9 & 18.3 & 20.5 & 18.8 & 19.1 & 18.3 & 18.0 & 17.8 & 17.5 & 17.3 \\
\hline Current & 12.7 & 12.7 & 13.3 & 13.9 & 15.3 & 14.2 & 14.1 & 13.9 & 13.8 & 13.7 & 13.7 & 13.7 \\
\hline Wages & 6.0 & 5.9 & 5.8 & 5.9 & 6.4 & 6.3 & 6.1 & 5.9 & 5.7 & 5.5 & 5.3 & 5.2 \\
\hline Pensions & 1.9 & 1.9 & 2.1 & 2.1 & 2.4 & 2.4 & 2.3 & 2.5 & 2.6 & 2.7 & 2.9 & 3.1 \\
\hline Subsidies and transfers & 2.2 & 2.2 & 2.3 & 2.7 & 3.1 & 2.9 & 2.8 & 2.8 & 2.8 & 2.8 & 2.8 & 2.8 \\
\hline Other & 2.5 & 2.8 & 3.1 & 3.2 & 3.4 & 2.6 & 2.8 & 2.8 & 2.8 & 2.7 & 2.7 & 2.6 \\
\hline Capital & 3.1 & 3.2 & 3.6 & 4.4 & 5.1 & 4.6 & 5.0 & 4.4 & 4.2 & 4.1 & 3.8 & 3.6 \\
\hline Physical capital & 2.5 & 2.6 & 2.8 & 3.1 & 4.6 & 4.5 & 4.7 & 4.2 & 4.0 & 3.9 & 3.7 & 3.5 \\
\hline Of which: non Pemex & 2.3 & 2.4 & 2.5 & 2.5 & 2.5 & 2.4 & 2.7 & 2.2 & 2.0 & 1.9 & 1.7 & 1.5 \\
\hline Financial capital & 0.6 & 0.6 & 0.8 & 1.3 & 0.5 & 0.1 & 0.3 & 0.2 & 0.1 & 0.1 & 0.1 & 0.1 \\
\hline Nonprogrammable & 3.1 & 3.4 & 3.1 & 3.6 & 3.3 & 3.6 & 3.3 & 3.3 & 3.4 & 3.3 & 3.3 & 3.2 \\
\hline Of which: revenue sharing & 3.0 & 3.2 & 3.0 & 3.5 & 3.2 & 3.5 & 3.2 & 3.2 & 3.3 & 3.2 & 3.2 & 3.1 \\
\hline Interest payments $2 /$ & 2.3 & 2.4 & 2.1 & 1.9 & 2.2 & 2.3 & 2.2 & 2.3 & 2.4 & 2.5 & 2.5 & 2.6 \\
\hline Traditional balance 3 & -0.1 & 0.1 & 0.0 & -0.1 & -2.3 & -2.8 & -2.7 & -2.3 & -2.0 & -2.0 & -2.0 & -2.0 \\
\hline Traditional balance for balanced budget rule & $\ldots$ & $\ldots$ & 0.0 & -0.1 & -0.2 & -0.7 & -0.7 & -0.3 & 0.0 & 0.0 & 0.0 & 0.0 \\
\hline Adjustments to the traditional balance & 1.4 & 1.3 & 1.5 & 1.4 & 2.4 & 1.3 & 0.8 & 0.8 & 0.7 & 0.6 & 0.6 & 0.6 \\
\hline PIDIREGAS & 0.8 & 1.1 & 0.9 & 1.1 & 0.0 & 0.1 & 0.1 & 0.1 & 0.1 & 0.1 & 0.1 & 0.1 \\
\hline $\mathbb{P A B}$ & 0.2 & 0.1 & 0.1 & 0.2 & 0.1 & 0.2 & 0.2 & 0.1 & 0.1 & 0.1 & 0.1 & 0.1 \\
\hline Budgetary adjustments & 0.1 & 0.2 & 0.4 & 0.3 & 0.3 & 0.3 & 0.3 & 0.3 & 0.2 & 0.2 & 0.2 & 0.2 \\
\hline PEMEX, oil stabilization fund, FARP (-: net inflow s) & -0.1 & -0.5 & -0.4 & -1.0 & 0.7 & 0.3 & -0.3 & -0.2 & -0.1 & -0.1 & -0.1 & -0.1 \\
\hline FARAC & 0.0 & 0.0 & -0.2 & 0.0 & 0.0 & 0.0 & 0.0 & 0.0 & 0.0 & 0.0 & 0.0 & 0.0 \\
\hline Debtor support & 0.0 & 0.0 & 0.0 & 0.0 & 0.0 & 0.0 & 0.0 & 0.0 & 0.0 & 0.0 & 0.0 & 0.0 \\
\hline Development bar & 0.0 & 0.1 & 0.1 & 0.0 & 0.0 & 0.0 & 0.0 & 0.0 & 0.0 & 0.0 & 0.0 & 0.0 \\
\hline Nonrecurring revenue & 0.2 & 0.3 & 0.6 & 0.7 & 1.3 & 0.4 & 0.5 & 0.4 & 0.4 & 0.4 & 0.4 & 0.4 \\
\hline Augmented balance (excl. net lending of dev. $k$ & -1.4 & -1.0 & -1.4 & -1.5 & -4.7 & -4.1 & -3.4 & -3.0 & -2.7 & -2.6 & -2.6 & -2.6 \\
\hline Augmented & 2.9 & 2.8 & 2.7 & 2.5 & 2.7 & 2.4 & 2.6 & 2.6 & 2.6 & 2.6 & 2.7 & 2.7 \\
\hline Augmented primary balance (excl. dev. Banks) $5 /$ & 1.5 & 1.8 & 1.3 & 1.1 & -2.0 & -1.6 & -0.9 & -0.5 & -0.1 & 0.0 & 0.0 & 0.1 \\
\hline \multicolumn{13}{|l|}{ Memorandum items } \\
\hline Crude oil export price, Me & 42.8 & 53.1 & 61.7 & 84.4 & 57.7 & 59.0 & 70.8 & 74.7 & 75.0 & 76.6 & 78.3 & 80.6 \\
\hline Development banks & -0.1 & -0.5 & 0.0 & 0.4 & 0.4 & 0.5 & 0.5 & 0.4 & 0.3 & 0.3 & 0.3 & 0.3 \\
\hline Augmented balance (incl. n & -1.3 & -0.6 & -1.4 & -1.8 & -5.1 & -4.5 & -3.9 & -3.4 & -3.0 & -3.0 & -3.0 & -3.0 \\
\hline Augmented primary balance (incl. net lending of de & 1.6 & 2.2 & 1.2 & 0.7 & -2.4 & -2.1 & -1.4 & -0.9 & -0.4 & -0.4 & -0.3 & -0.2 \\
\hline Non-oil augmented balance $6 /$ & -6.4 & -5.8 & -6.5 & -7.5 & -9.5 & $\ldots$ & -7.5 & -6.7 & -6.0 & -5.9 & -5.8 & -5.7 \\
\hline Oil augmented balance & 5.0 & 5.2 & 5.0 & 5.7 & 4.3 & $\ldots$ & 3.6 & 3.3 & 3.0 & 2.9 & 2.8 & 2.7 \\
\hline Gross public sector debt & 39.8 & 38.3 & 38.2 & 43.3 & 44.6 & $\ldots$ & 44.6 & 44.2 & 43.4 & 42.8 & 42.5 & 42.4 \\
\hline Domestic (percentage o & 67.9 & 73.5 & 73.0 & 70.3 & 73.1 & $\ldots$ & 75.5 & 77.3 & 79.0 & 80.3 & 81.6 & 82.9 \\
\hline External (percentage of total debt) & 32.1 & 26.5 & 27.0 & 29.7 & 26.9 & $\ldots$ & 24.5 & 22.7 & 21.0 & 19.7 & 18.4 & 17.1 \\
\hline Net public sector debt & 35.2 & 32.4 & 31.4 & 35.8 & 38.8 & $\ldots$ & 39.1 & 39.0 & 38.5 & 38.1 & 38.0 & 38.1 \\
\hline Nominal GDP (billions of Mexican pesos) & 9,252 & 10,382 & 11,208 & 12,131 & 1,823 & 12,793 & 13,171 & 14,337 & 15,591 & 16,885 & 18,175 & 19,470 \\
\hline
\end{tabular}

Sources: Mexican authorities; and IMF staff estimates. Data refer to non-financial public sector, including PEMEX and other public enterprises but excluding state and local governments (except as noted).

$1 /$ Total tax revenue excluding excise tax on gasoline.

2/ Includes transfers to IPAB and the debtor support programs.

$3 /$ The break in the series in 2009 is due to definitional and accounting changes

4/ Public Sector Borrow ing Requirements excl. nonrecurrent revenue.

5/ Treats transfers to IPAB as interest payments.

6/ Excludes oil revenue (oil extraction rights, PEMEX net income, oil excess return levies, excise tax on gasoline) and PEMEX operational expenditure, interest payments, and capital expenditure. 
Table 3. Mexico: Summary Balance of Payments, 2005-15

\begin{tabular}{|c|c|c|c|c|c|c|c|c|c|c|c|}
\hline & & & & & Est. & & & Projec & & & \\
\hline & 2005 & 2006 & 2007 & $2008^{-}$ & 2009 & 2010 & 2011 & 2012 & 2013 & 2014 & 2015 \\
\hline \multicolumn{12}{|c|}{ (In billions of U.S. dollars) } \\
\hline Current account & -4.5 & -4.4 & -8.4 & -15.9 & -5.2 & -14.0 & -15.6 & -19.9 & -19.7 & -19.3 & -19.5 \\
\hline Merchandise trade balance, f.o.b. & -7.6 & -6.1 & -10.1 & -17.3 & -4.7 & -9.1 & -12.4 & -17.5 & -17.5 & -18.1 & -18.9 \\
\hline Exports & 214.2 & 249.9 & 271.9 & 291.3 & 229.7 & 276.2 & 297.5 & 319.7 & 344.8 & 370.8 & 398.3 \\
\hline Imports & -221.8 & -256.1 & -281.9 & -308.6 & -234.4 & -285.3 & -309.9 & -337.2 & -362.3 & -388.9 & -417.2 \\
\hline Factor income & -14.4 & -18.5 & -18.4 & -17.0 & -14.1 & -17.9 & -17.3 & -17.8 & -19.2 & -19.9 & -19.5 \\
\hline Net services & -4.7 & -5.7 & -6.3 & -7.1 & -8.0 & -8.5 & -9.3 & -10.1 & -10.9 & -11.5 & -12.0 \\
\hline Net transfers & 22.1 & 25.9 & 26.4 & 25.5 & 21.5 & 21.5 & 23.5 & 25.6 & 27.9 & 30.2 & 30.9 \\
\hline of which Remittances & 21.7 & 25.6 & 26.1 & 25.1 & 21.2 & 21.2 & 23.1 & 25.2 & 27.5 & 29.7 & 30.4 \\
\hline Financial account & 14.8 & -2.7 & 19.7 & 24.5 & 14.6 & 29.0 & 30.6 & 29.9 & 24.7 & 24.3 & 21.5 \\
\hline Public sector $1 /$ & 1.4 & -12.5 & 14.1 & 14.9 & 27.3 & 11.4 & -0.1 & 0.7 & 1.8 & 1.8 & 1.8 \\
\hline Medium- and long-term borrow ing & -7.3 & -20.5 & -5.1 & -1.1 & 18.2 & 8.2 & -2.5 & -1.9 & -1.0 & -1.0 & -1.0 \\
\hline Disbursements & 6.8 & 9.8 & 6.6 & 10.0 & 29.3 & 17.2 & 11.0 & 11.4 & 12.2 & 12.1 & 12.1 \\
\hline Amortization 2/ & 14.1 & 30.3 & 11.7 & 11.1 & 11.1 & 9.0 & 13.5 & 13.3 & 13.2 & 13.1 & 13.1 \\
\hline Pidiregas, net $3 /$ & 8.7 & 7.0 & 13.2 & 12.9 & 0.0 & 0.0 & 0.0 & 0.0 & 0.0 & 0.0 & 0.0 \\
\hline Other, including short-term borrow ing and change in as؟ & 0.0 & 0.9 & 6.0 & 3.1 & 9.1 & 3.2 & 2.4 & 2.6 & 2.8 & 2.8 & 2.8 \\
\hline Of which: oil hedging capital income & & & & & 5.1 & & & & & & \\
\hline Private sector & 13.4 & 9.8 & 5.6 & 9.6 & -12.7 & 17.6 & 30.7 & 29.3 & 23.0 & 22.5 & 19.7 \\
\hline Direct investment, net & 15.9 & 14.0 & 19.1 & 22.0 & 3.8 & 17.5 & 18.3 & 19.1 & 20.1 & 20.1 & 20.2 \\
\hline Bonds and loans & 1.9 & 5.2 & 8.8 & -0.9 & -3.7 & 4.3 & 17.1 & 14.5 & 6.9 & 6.4 & 3.5 \\
\hline Equity investments and change in assets abroad & -4.4 & -9.4 & -22.3 & -11.4 & -12.9 & -4.3 & -4.7 & -4.4 & -4.0 & -4.0 & -4.0 \\
\hline Errors and omissions and valuation adjustments & -3.1 & 6.1 & -1.0 & -1.2 & -4.0 & 0.0 & 0.0 & 0.0 & 0.0 & 0.0 & 0.0 \\
\hline Net international reserves (increase -) & -7.1 & 1.0 & -10.4 & -7.4 & -5.4 & -15.0 & -15.0 & -10.0 & -5.0 & -5.0 & -2.0 \\
\hline \multicolumn{12}{|c|}{ (In percent of GDP, unless otherw ise indicated) } \\
\hline \multicolumn{12}{|l|}{ Memorandum items: } \\
\hline Current account balance & -0.5 & -0.5 & -0.8 & -1.5 & -0.6 & -1.4 & -1.5 & -1.7 & -1.6 & -1.5 & -1.4 \\
\hline Nonoil current account balance 4/ & -2.3 & -2.5 & -2.7 & -3.0 & -1.8 & -1.9 & -1.4 & -1.1 & -0.7 & -0.1 & 0.2 \\
\hline Nonoil trade balance $4 /$ & -2.7 & -2.6 & -2.9 & -3.1 & -1.7 & -1.4 & -1.1 & -0.9 & -0.5 & -0.1 & 0.3 \\
\hline Oil trade balance & 1.8 & 2.0 & 1.9 & 1.5 & 1.2 & 0.5 & 0.0 & -0.6 & -0.9 & -1.3 & -1.6 \\
\hline Gross financing needs (billions of US $\$$ ) 4/ & 59.2 & 70.0 & 70.4 & 80.0 & 68.1 & 76.9 & 84.5 & 97.0 & 102.6 & 104.9 & 104.0 \\
\hline Gross international reserves (change, billions of US $\$$ ) $5 /$ & 9.9 & 2.2 & 10.9 & 8.1 & 4.6 & 15.0 & 15.0 & 10.0 & 5.0 & 5.0 & 2.0 \\
\hline End-year (billions of US\$) & 74.1 & 76.3 & 87.2 & 95.3 & 99.9 & 114.9 & 129.9 & 139.9 & 144.9 & 149.9 & 151.9 \\
\hline Months of imports of goods and services & 3.2 & 3.0 & 3.1 & 4.4 & 3.9 & 4.1 & 4.3 & 4.3 & 4.1 & 4.0 & $\ldots$ \\
\hline Months of imports plus interest payments & 3.4 & 3.1 & 3.3 & 4.7 & 4.1 & 4.3 & 4.5 & 4.5 & 4.3 & 4.1 & $\ldots$ \\
\hline Percent of short-term debt (by residual maturity) $6 /$ & 111.4 & 147.7 & 153.9 & 165.9 & 208.3 & 213.4 & 193.7 & 179.6 & 179.8 & 181.7 & \\
\hline Gross total external debt & 20.4 & 17.8 & 18.8 & 18.5 & 23.8 & 22.6 & 22.7 & 22.4 & 21.5 & 20.7 & 19.9 \\
\hline Of which: Public external debt & 12.4 & 9.8 & 10.0 & 10.3 & 11.5 & 10.9 & 10.0 & 9.1 & 8.4 & 7.8 & 7.2 \\
\hline Gross total external debt (billions of US $\$$ ) & 173.1 & 169.1 & 193.1 & 201.2 & 209.6 & 225.3 & 242.3 & 257.5 & 266.1 & 274.3 & 279.5 \\
\hline Of which: Public external debt $7 /$ & 104.9 & 93.1 & 102.6 & 112.2 & 100.9 & 109.1 & 106.6 & 104.7 & 103.7 & 102.7 & 101.7 \\
\hline \multirow{2}{*}{$\begin{array}{l}\text { Public external debt service (in percent of exports } \\
\text { of goods, services, and transfers) } 8 /\end{array}$} & & & & & & & & & & & \\
\hline & 9.4 & 14.3 & 7.5 & 6.8 & 6.7 & 6.0 & 6.9 & 6.8 & 6.5 & 6.0 & 5.4 \\
\hline
\end{tabular}

Sources: Bank of Mexico; Secretariat of Finance and Public Credit; and Fund staff projections.

$1 /$ Including the financing of PIDIREGAS.

2/ Includes pre-payment of external debt.

3/ Break in the series in 2009 due to accounting changes.

4/ Excluding oil exports and petroleum products imports.

5/ Excludes balances under bilateral payments accounts. For 2009, includes the allocation of SDR 2.337 billion in the general allocation implemented on August 28 , 2009, and another SDR 0.224 billion in the special allocation on September 9.

$6 /$ In percent of short-term debt by residual maturity. Historical data include all prepayments.

$7 /$ Includes gross external debt of the federal government, development banks and nonfinancial public enterprises, and is adjusted for PIDIREGAS.

$8 /$ Includes amortization on medium and long-term bonds and debt, and interest payments. 
Table 4. Mexico: Financial Soundness Indicators (in percent)

\begin{tabular}{lcccccc}
\hline & $\mathbf{2 0 0 4}$ & $\mathbf{2 0 0 5}$ & $\mathbf{2 0 0 6}$ & $\mathbf{2 0 0 7}$ & $\mathbf{2 0 0 8}$ & $\mathbf{2 0 0 9} \mathbf{1 /}$ \\
\hline Capital Adequacy & & & & & & \\
Regulatory capital to risk-weighted assets & 14.1 & 14.3 & 16.1 & 15.9 & 15.3 & 15.9 \\
Regulatory Tier 1 capital to risk-weighted assets & 12.8 & 13.4 & 15.1 & 14.7 & 13.3 & 14.0 \\
Capital to assets & 11.2 & 12.5 & 13.6 & 13.8 & 9.2 & 10.1 \\
Gross asset position in financial derivatives to capital & 15.8 & 24.3 & 35.3 & 36.1 & 47.1 & $\ldots$ \\
Gross liability position in financial derivatives to capital & 14.1 & 21.5 & 33.8 & 35.0 & 47.7 & $\ldots$ \\
& & & & & & \\
Asset Quality & & & & & & \\
Nonperforming loans to total gross loans & 2.5 & 1.8 & 2.0 & 2.7 & 3.2 & 3.4 \\
Provisions to Nonperforming loans & 202.6 & 242.2 & 210.3 & 168.9 & 161.2 & 163.8 \\
& & & & & & \\
Earnings and Profitability & & & & & & \\
Return on assets & 2.1 & 3.2 & 3.5 & 2.7 & 1.1 & 1.2 \\
Return on equity & 19.0 & 25.4 & 25.9 & 19.9 & 8.9 & 12.7 \\
Personnel expenses to noninterest expenses & 87.5 & 86.0 & 88.3 & 88.0 & 87.7 & 87.1 \\
& & & & & & \\
Liquidity & & & & & & \\
Liquid assets to short-term liabilities & 106.0 & 94.5 & 85.1 & 81.0 & 83.5 & 82.5 \\
Liquid assets to total assets & 35.2 & 33.7 & 30.3 & 28.7 & 25.0 & 24.4 \\
Customer deposits to total (noninterbank) loans & 119.1 & 120.1 & 107.4 & 95.8 & 99.6 & 92.7 \\
& & & & & & \\
Sensitivity to market risk & & & & & & \\
Net open position in equities to capital & 16.8 & 13.7 & 13.0 & 13.8 & 16.6 & $\ldots$ \\
\hline Source: CNBV & & & & &
\end{tabular}

1. As of end-September 2009, and staff estimates. 
Table 5. Mexico: Indicators of External Vulnerability, 2005-2009

\begin{tabular}{|c|c|c|c|c|c|c|c|c|}
\hline & 2005 & 2006 & 2007 & 2008 & \multicolumn{4}{|c|}{2009} \\
\hline & Dec. & Dec. & Dec. & Dec. & Mar. & Jun. & Sep. & Dec. \\
\hline \multicolumn{9}{|l|}{ Financial Market indicators } \\
\hline Exchange rate (per U.S. dollar, end-period) & 10.6 & 10.8 & 10.9 & 13.8 & 14.2 & 13.2 & 13.5 & 13.1 \\
\hline (year-to-date percent change) & -4.6 & 1.7 & 1.0 & 26.7 & 30.9 & 21.8 & 24.8 & 20.9 \\
\hline 28-day treasury auction rate (percent; period average) & 8.2 & 7.0 & 7.4 & 8.0 & 7.2 & 5.0 & 4.5 & 4.5 \\
\hline EMBI+ Mexico (basis points; period average) & 125 & 105 & 159 & 408 & 385 & 236 & 207 & 172 \\
\hline Stock exchange index in U.S. dollar terms (year-to-date percent change) & 44.5 & 46.1 & 10.6 & -40.2 & -43.3 & -24.4 & -11.4 & 0.5 \\
\hline \multicolumn{9}{|l|}{ Financial system } \\
\hline Bank of Mexico net international reserves (US\$ billion) & 68.7 & 67.7 & 78.0 & 85.4 & 78.9 & 74.2 & 76.1 & 85.4 \\
\hline Real Credit to the private sector (12-month percent change) & 13.7 & 25.3 & 22.6 & -0.6 & 2.3 & -1.6 & -0.2 & $\ldots$ \\
\hline Commercial banks' nonperforming loans (percent of total loans) & 1.8 & 2.0 & 2.7 & 3.2 & 3.4 & 3.8 & 3.4 & 3.1 \\
\hline Commercial banks' loan loss provision (percent of nonperforming loans) & 241.3 & 208.4 & 169.2 & 161.2 & 158.7 & $\ldots$ & 163.8 & $\ldots$ \\
\hline \multicolumn{9}{|l|}{ Exports and Imports } \\
\hline Trade balance (US\$ billion; year-to-date) & -7.6 & -6.1 & -10.1 & -17.3 & -2.0 & -1.2 & -4.3 & -4.7 \\
\hline \multicolumn{9}{|l|}{ Of which } \\
\hline Non-oil & 11.0 & 15.7 & 8.5 & 5.2 & -22.1 & -24.4 & -23.5 & -17.4 \\
\hline \multicolumn{9}{|l|}{ Of which } \\
\hline Consumer goods & 24.0 & 17.1 & 16.7 & 11.3 & -37.6 & -38.8 & -36.8 & -31.5 \\
\hline Capital goods & 16.0 & 16.4 & 10.1 & 16.4 & -10.6 & -21.3 & -23.4 & -21.6 \\
\hline Terms of trade (12-month percent change) & 3.0 & 2.9 & -0.3 & 1.3 & $\ldots$ & $\ldots$ & $\ldots$ & -11.3 \\
\hline Real effective exchange rate (CPI based; 12-month percent change) 2/ & 7.2 & -1.9 & -1.6 & -12.8 & -20.1 & -16.0 & -16.6 & 3.6 \\
\hline \multicolumn{9}{|l|}{ External Debt } \\
\hline Nonfinancial public sector external debt (percent of GDP) & 12.2 & 9.4 & 8.3 & 9.2 & $\ldots$ & $\ldots$ & $\ldots$ & 11.5 \\
\hline Nonfinancial public sector short-term external debt (percent of GDP) 3/ & 0.1 & 0.1 & 0.1 & 0.1 & $\ldots$ & $\ldots$ & $\ldots$ & 0.1 \\
\hline Private sector external debt (percent of GDP) & 8.0 & 8.0 & 8.8 & 8.1 & $\ldots$ & $\ldots$ & $\ldots$ & 9.7 \\
\hline Private sector short-term external debt (percent of GDP) & 2.3 & 2.3 & 2.5 & 2.2 & $\ldots$ & $\ldots$ & $\ldots$ & 1.8 \\
\hline \multicolumn{9}{|l|}{ Memorandum items: } \\
\hline Gross international reserves to short-term debt (by residual maturity, percent) & 111.4 & 147.8 & 153.9 & 165.9 & $\ldots$ & $\ldots$ & $\ldots$ & 239.3 \\
\hline Monetary base to gross international reserves (percent) & 48.2 & 54.5 & 52.0 & 43.8 & 44.0 & 49.5 & 44.3 & 48.4 \\
\hline Net international reserves to $\mathrm{M} 2$ & 16.8 & 14.8 & 15.9 & 18.8 & 17.5 & 15.4 & 16.0 & 17.9 \\
\hline
\end{tabular}

Sources: Bank of Mexico; National Banking and Securities Commission; National Institute of Statistics and Geography; Secretariat of Finance and Public Credit; and IMF staff estimates.

$1 /$ In U.S. dollar terms.

2/ Increase signifies appreciation.

3/ Short-term debt by residual maturity includes pre-payment of debt. 
Table 6. Mexico: Baseline Medium-Term Projections, 2005-2015

\begin{tabular}{|c|c|c|c|c|c|c|c|c|c|c|c|}
\hline & \multirow[b]{2}{*}{2005} & \multirow[b]{2}{*}{2006} & \multirow[b]{2}{*}{2007} & \multirow[b]{2}{*}{2008} & \multirow[b]{2}{*}{2009} & \multirow[b]{2}{*}{2010} & \multicolumn{3}{|c|}{ Staff Projections } & \multirow[b]{2}{*}{2014} & \multirow[b]{2}{*}{2015} \\
\hline & & & & & & & 2011 & 2012 & 2013 & & \\
\hline \multicolumn{12}{|c|}{ (Annual percentage change, unless otherw ise indicated) } \\
\hline \multicolumn{12}{|l|}{ National income and prices } \\
\hline Real GDP & 3.2 & 5.1 & 3.3 & 1.3 & -6.6 & 4.0 & 4.5 & 5.2 & 4.9 & 4.4 & 4.0 \\
\hline Consumer prices (end of year) & 3.3 & 4.0 & 3.7 & 6.5 & 3.5 & 5.3 & 3.0 & 3.0 & 3.0 & 3.0 & 3.0 \\
\hline Consumer prices (average) & 4.0 & 3.6 & 4.0 & 5.1 & 5.3 & 4.6 & 3.7 & 3.0 & 3.0 & 3.0 & 3.0 \\
\hline \multicolumn{12}{|l|}{ External sector } \\
\hline Nonoil current account balance 1/ & -2.3 & -2.5 & -2.7 & -3.0 & -1.9 & -2.0 & -1.5 & -1.2 & -0.7 & -0.2 & 0.1 \\
\hline Exports, f.o.b. & 14.0 & 16.7 & 8.8 & 7.2 & -21.2 & 19.6 & 7.6 & 7.4 & 7.9 & 7.5 & 7.4 \\
\hline Imports, f.o.b. & 12.7 & 15.4 & 10.1 & 9.5 & -24.0 & 21.7 & 8.6 & 8.8 & 7.4 & 7.3 & 7.3 \\
\hline Oil export price (US\$ / bbl) & 42.8 & 53.1 & 61.7 & 84.4 & 57.8 & 70.8 & 74.8 & 75.1 & 76.6 & 78.4 & 80.6 \\
\hline \multicolumn{12}{|l|}{ Interest rates } \\
\hline Treasury bill rate (average 28-day cetes) & 9.2 & 7.2 & 7.2 & 7.6 & 5.4 & 4.9 & 6.2 & 6.3 & 6.3 & 6.3 & 6.3 \\
\hline Real interest rate (28-day cetes) & 5.0 & 3.4 & 3.1 & 2.4 & 0.1 & 0.3 & 2.4 & 3.2 & 3.3 & 3.2 & 3.2 \\
\hline \multicolumn{12}{|c|}{ (In percent of GDP) } \\
\hline \multicolumn{12}{|l|}{ Nonfinancial public sector } \\
\hline Augmented balance & -1.4 & -1.0 & -1.4 & -1.5 & -4.7 & -3.4 & -3.0 & -2.7 & -2.6 & -2.6 & -2.6 \\
\hline Augmented primary balance & 1.5 & 1.8 & 1.3 & 1.1 & -2.0 & -0.9 & -0.5 & -0.1 & 0.0 & 0.0 & 0.1 \\
\hline \multicolumn{12}{|l|}{ Saving and investment } \\
\hline Gross domestic investment & 24.4 & 26.1 & 25.8 & 26.4 & 22.1 & 21.9 & 22.5 & 23.3 & 23.7 & 23.8 & 23.6 \\
\hline Fixed investment & 20.2 & 20.9 & 21.4 & 22.1 & 21.4 & 19.6 & 19.5 & 19.7 & 19.8 & 19.8 & 19.7 \\
\hline Public & 4.6 & 4.3 & 4.7 & 5.5 & 5.8 & 5.0 & 4.4 & 4.1 & 4.0 & 3.8 & 3.6 \\
\hline Private & 15.6 & 16.5 & 16.7 & 16.6 & 15.7 & 14.9 & 15.3 & 15.5 & 15.8 & 16.1 & 16.4 \\
\hline Gross national saving & 23.8 & 25.7 & 25.0 & 24.9 & 21.4 & 20.4 & 20.9 & 21.5 & 22.0 & 22.3 & 22.2 \\
\hline Public sector & 3.2 & 3.7 & 3.3 & 3.7 & 0.6 & 1.1 & 0.9 & 1.2 & 1.0 & 0.8 & 0.6 \\
\hline Private sector & 20.6 & 22.0 & 21.7 & 21.2 & 20.7 & 19.2 & 20.0 & 20.3 & 21.0 & 21.5 & 21.6 \\
\hline Current account balance & -0.5 & -0.5 & -0.8 & -1.5 & -0.6 & -1.4 & -1.5 & -1.7 & -1.6 & -1.5 & -1.4 \\
\hline
\end{tabular}

Sources: Bank of Mexico; National Institute of Statistics and Geography; Secretariat of Finance and Public Credit; and IMF staff projections 1/ Excluding oil exports and petroleum products imports.

2/ Excluding oil revenues, Pemex expenditures, and oil investments. 
Table 7. Country: Gross Public Sector Debt Sustainability Framework, 2005-2015 (In percent of GDP, unless otherwise indicated)

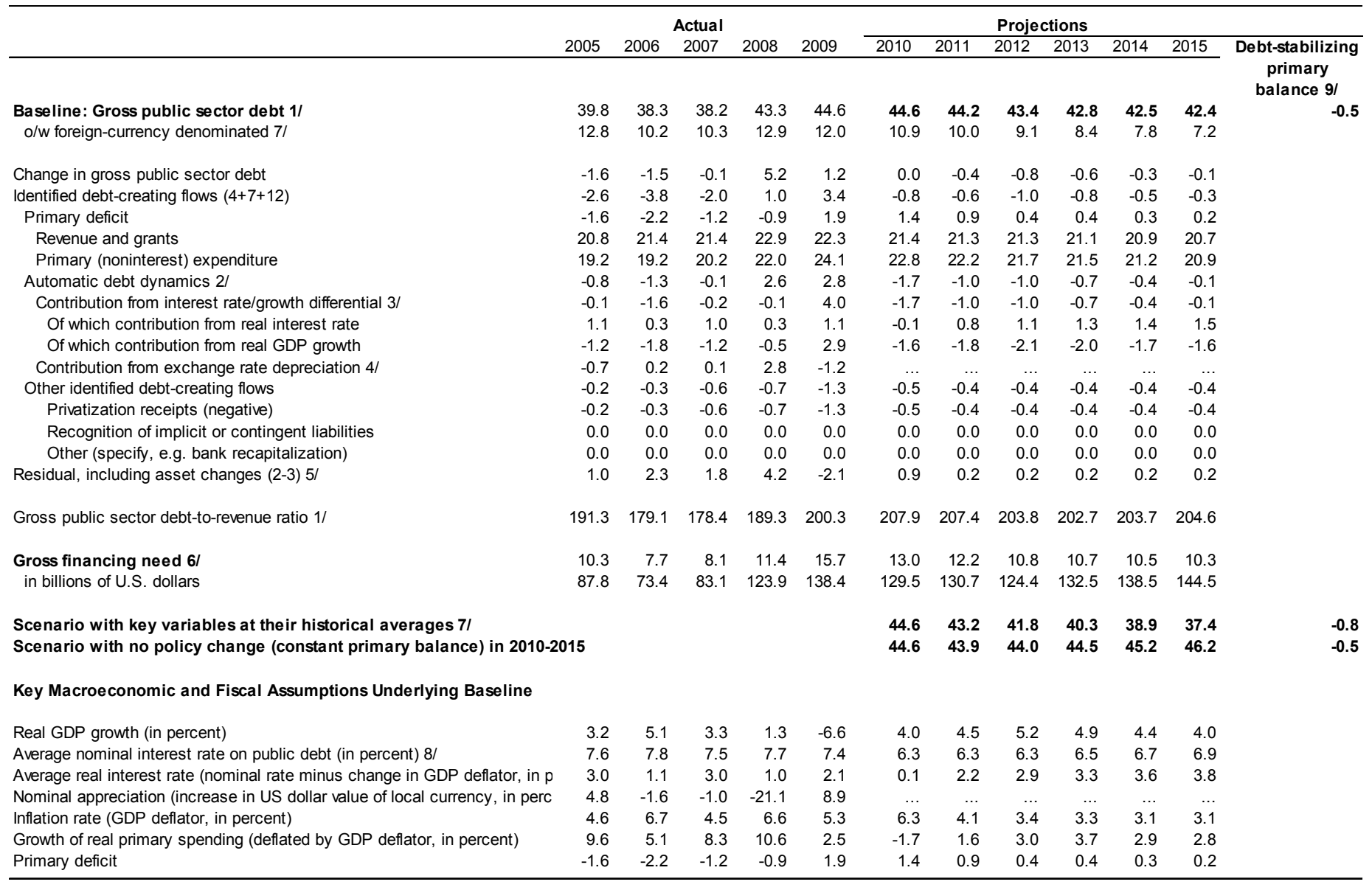

1/ Public sector includes federal government, Pemex, and other public compaies, development banks, Pidiregas, IPAB, debtors' program, and Farac.

2/ Derived as $\left[\left(r-\pi(1+g)-g+\alpha_{\varepsilon}(1+r)\right](1+g+\pi+g \pi)\right)$ times previous period debt ratio, with $r=$ interest rate; $\pi=$ growth rate of GDP deflator; $g=$ real GDP growth rate; $\alpha=$ share of foreign-currency denominated debt; and $\varepsilon=$ nominal exchange rate depreciation (measured by increase in local currency value of U.S. dollar).

$3 /$ The real interest rate contribution is derived from the denominator in footnote $2 /$ as $r-\pi(1+g)$ and the real growth contribution as $-\mathrm{g}$.

$4 /$ The exchange rate contribution is derived from the numerator in footnote $2 /$ as $\alpha \varepsilon(1+r)$.

$5 /$ For projections, this line includes exchange rate changes.

6/ Defined as public sector deficit, plus amortization of medium and long-term public sector debt, plus short-term debt at end of previous period.

7/ The key variables include real GDP growth; real interest rate; and primary balance in percent of GDP.

$8 /$ Derived as nominal interest expenditure divided by previous period debt stock.

9/ Assumes that key variables (real GDP growth, real interest rate, and other identified debt-creating flows) remain at the level of the last projection year. 
Table 8. Mexico: External Debt Sustainability Framework, 2005-15

(In percent of GDP, unless otherwise indicated)

\begin{tabular}{|c|c|c|c|c|c|c|c|c|c|c|c|c|}
\hline & \multicolumn{5}{|c|}{ Actual } & \multicolumn{7}{|c|}{ Projections } \\
\hline & 2005 & 2006 & 2007 & 2008 & 2009 & 2010 & 2011 & 2012 & 2013 & 2014 & 2015 & Debt-s tabilizing \\
\hline Baseline: External debt & 20.4 & 17.8 & 18.8 & 18.5 & 23.8 & 22.6 & 22.7 & 22.4 & 21.5 & 20.7 & 19.9 & $\begin{array}{c}\text { current account } 7 \\
-1.8\end{array}$ \\
\hline Change in external debt & -1.5 & -2.6 & 1.1 & -0.3 & 5.3 & -1.2 & 0.1 & -0.4 & -0.9 & -0.8 & -0.9 & \\
\hline Identified external debt-creating flows $(4+8+9)$ & -3.9 & -3.5 & -2.5 & -0.8 & 3.6 & -1.2 & -1.4 & -1.3 & -1.3 & -1.2 & -1.1 & \\
\hline Current account deficit, excluding interest payments & -0.9 & -1.0 & -0.6 & 0.1 & -0.7 & 0.0 & 0.1 & 0.4 & 0.2 & 0.1 & 0.2 & \\
\hline Deficit in balance of goods and services & 1.4 & 1.2 & 1.6 & 2.2 & 1.4 & 1.8 & 2.0 & 2.4 & 2.3 & 2.2 & 2.2 & \\
\hline Exports & 27.1 & 27.9 & 28.2 & 28.4 & 27.8 & 29.2 & 29.4 & 29.3 & 29.4 & 29.5 & 29.8 & \\
\hline Imports & 28.6 & 29.2 & 29.8 & 30.7 & 29.2 & 31.0 & 31.5 & 31.7 & 31.6 & 31.8 & 32.0 & \\
\hline Net non-debt creating capital inflows (negative) & -2.2 & -1.7 & -2.1 & -1.1 & -1.3 & -1.8 & -1.9 & -1.9 & -1.9 & -1.8 & -1.7 & \\
\hline Automatic debt dynamics 1/ & -0.9 & -0.7 & 0.2 & 0.3 & 5.7 & 0.6 & 0.4 & 0.3 & 0.4 & 0.4 & 0.4 & \\
\hline Contribution from nominal interest rate & 1.4 & 1.5 & 1.4 & 1.3 & 1.3 & 1.4 & 1.3 & 1.3 & 1.4 & 1.3 & 1.2 & \\
\hline Contribution from real GDP growth & -0.6 & -0.9 & -0.5 & -0.2 & 1.5 & -0.8 & -0.9 & -1.1 & -1.0 & -0.9 & -0.8 & \\
\hline Contribution from price and exchange rate changes $2 /$ & -1.7 & -1.3 & -0.7 & -0.8 & 2.9 & $\ldots$ & $\ldots$ & $\ldots$ & $\ldots$ & $\ldots$ & $\ldots$ & \\
\hline Residual, incl. change in gross foreign assets (2-3) $3 /$ & 2.4 & 0.8 & 3.6 & 0.4 & 1.7 & 0.0 & 1.5 & 0.9 & 0.4 & 0.4 & 0.2 & \\
\hline External debt-to-exports ratio (in percent) & 75.2 & 63.5 & 66.7 & 65.0 & 85.7 & 77.2 & 77.2 & 76.4 & 73.2 & 70.2 & 66.6 & \\
\hline Gross external financing need (in billions of US dollars) 4 / & 52.0 & 71.0 & 60.1 & 72.6 & 62.7 & 61.9 & 69.5 & 87.0 & 97.6 & 99.9 & 102.0 & \\
\hline in percent of GDP & 6.1 & 7.5 & 5.9 & 6.7 & 7.1 & 6.2 & 6.5 & 7.6 & 7.9 & 7.5 & 7.2 & \\
\hline Scenario with key variables at their historical averages 5 / & & & & & & 22.6 & 22.7 & 22.3 & 21.4 & 20.5 & 19.3 & -1.7 \\
\hline \multicolumn{13}{|l|}{ Key Macroeconomic Assumptions Underlying Baseline } \\
\hline Real GDP growth (in percent) & 3.2 & 5.1 & 3.3 & 1.3 & -6.6 & 4.0 & 4.5 & 5.2 & 4.9 & 4.4 & 4.0 & \\
\hline GDP deflator in US dollars (change in percent) & 8.3 & 6.7 & 4.2 & 4.7 & -13.4 & 8.8 & 2.3 & 2.6 & 2.5 & 2.4 & 2.3 & \\
\hline Nominal external interest rate (in percent) & 7.4 & 8.1 & 8.8 & 7.5 & 5.9 & 6.8 & 6.3 & 6.4 & 6.8 & 6.6 & 6.0 & \\
\hline Growth of exports (US dollar terms, in percent) 6/ & 14.0 & 15.6 & 8.7 & 6.9 & -21.0 & 19.4 & 7.5 & 7.4 & 7.8 & 7.5 & 7.4 & \\
\hline Growth of imports (US dollar terms, in percent) 6/ & 12.6 & 14.6 & 10.0 & 9.2 & -22.9 & 20.3 & 8.4 & 8.7 & 7.4 & 7.3 & 7.2 & \\
\hline Current account balance, excluding interest payments & 0.9 & 1.0 & 0.6 & -0.1 & 0.7 & 0.0 & -0.1 & -0.4 & -0.2 & -0.1 & -0.2 & \\
\hline Net non-debt creating capital inflows & 2.2 & 1.7 & 2.1 & 1.1 & 1.3 & 1.8 & 1.9 & 1.9 & 1.9 & 1.8 & 1.7 & \\
\hline
\end{tabular}

1/ Derived as $[\mathrm{r}-\mathrm{g}-\rho(1+\mathrm{g})+\varepsilon \alpha(1+\mathrm{r})] /\left(1+\mathrm{g}+\rho^{+} \mathrm{g}_{\rho}\right)$ times previous period debt stock, with $\mathrm{r}=$ nominal effective interest rate on external debt; $\rho=$ change in domestic GDP deflator in US dollar terms, $\mathrm{g}=$ real GD growth rate, $\mathrm{e}=$ nominal ap preciation (increase in dollar value of domestic currency), and $\mathrm{a}=$ share of domestic-currency denominated debt in total external debt.

$2 /$ The contribution from price and exchange rate changes is defined as $[-\rho(1+\mathrm{g})+\varepsilon \alpha(1+\mathrm{r})] /(1+\mathrm{g}+\rho+\mathrm{g} \rho)$ times previous period debt stock. $\rho$ increases with an appreciating domestic currency $(\varepsilon>0)$ and rising inflation

3/ For projection, line includes the impact of price and exchange rate changes.

4/Defined as current account deficit, plus amortization on medium- and long-term debt, plus short-term debt at end of previous period.

5/ The key variables include real GDP growth; nominal interest rate; dollar deflator growth; and both non-interest current account and non-debt inflows in percent of GDP.

6/ Goods and nonfactor services.

7/ Long-run, constant balance that stabilizes the debt ratio assuming that key variables (real GDP growth, nominal interest rate, dollar deflator growth, and non-debt inflows in percent of GDP) remain at their levels of the last projection year. 


\section{INTERNATIONAL MONETARY FUND}

\section{MEXICO}

\section{Staff Report for the 2010 Article IV Consultation-Informational Annex}

Prepared by the Western Hemisphere Department

March 1, 2010

Contents

Annexes

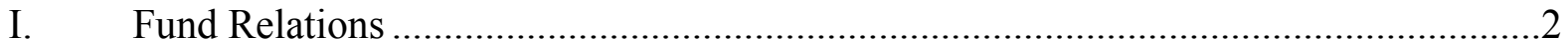

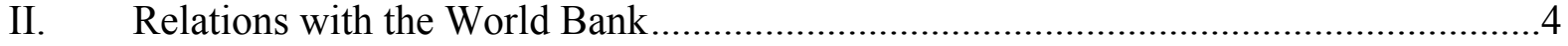

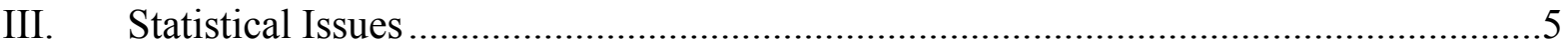




\section{ANNEX I. MeXiCo-Fund RELATIONS}

(As of January 31, 2010)

The 2010 Article IV discussions were held in Mexico City during February 2-12, 2010. The staff team comprised V. Haksar (Head), I. Vladkova Hollar and M.K. Tang (both WHD), G. Gasha (MCM), B. Joshi (SPR), G. Palomba (FAD), and K. Magnusson Bernard (EP-WHD). D. J. Robinson (WHD) joined for the second half of the mission and N. Eyzaguirre for the concluding meetings. The mission met with the Minister of Finance, the Governor and the members of the Board of the Bank of Mexico, senior staff of several government ministries and agencies, representatives of regulatory agencies, and private sector representatives. Messrs. Perez-Verdia and Jimenez (OED) attended most meetings.

Mexico has accepted the obligations of Article VIII, sections 2, 3, and 4, and does not have restrictions on payments for current international transactions.

Comprehensive economic data are available for Mexico on a timely basis. It subscribes to the SDDS, and economic data are adequate to conduct surveillance.

I. Membership Status: Joined December 31, 1945; Article VIII.

II. General Resources Account:

Quota

Fund holdings of currency

Reserve position in Fund

III. SDR Department:

Net cumulative allocation Holdings

IV. Outstanding Purchases and Loans:

V. Latest Financial Arrangements:

Type

FCLC

Stand-by

Stand-by

EFF

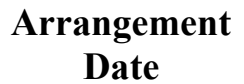

Apr 17, 2009

Jul 07, 1999

Feb 01, 1995

May 26, 1989
SDR Million

$3,152.80$

$2,539.79$

613.06

SDR Million

$2,851.20$

$2,886.66$

None
Apr 16, 2010

Nov 30, 2000

Feb 15, 1997

May 25, 1993

\author{
\% Quota \\ 100.00 \\ 80.56 \\ 19.44
}

\% Allocation
100.00
101.24
Amount Drawn (SDR Million) (SDR Million)

$31,528.00$

0.00

$3,103.00$

$12,070.20$

$3,729.60$
$1,939.50$

$8,758.02$

$3,263.40$ 
VI. Projected Payments to the Fund (SDR million):

Principal

Charges / Interest

Total

\begin{tabular}{|c|c|c|c|c|}
\hline \multicolumn{5}{|c|}{ Forthcoming } \\
\hline 2010 & 2011 & 2012 & 2013 & 2014 \\
\hline 0.21 & 0.21 & 0.21 & 0.21 & 0.21 \\
\hline 0.21 & $\overline{0.21}$ & 0.21 & 0.21 & 0.21 \\
\hline
\end{tabular}

VII. Exchange Rate Arrangement: Mexico has a floating exchange rate regime since December 22, 1994. Mexico maintains an exchange system that is free of restrictions on the making of payments and transfers for current international transactions.

VIII. Article IV. Consultation: The last Article IV consultation was concluded by the Executive Board on February 6, 2009. The relevant staff report was IMF country Report No. 09/53.

IX. Technical Assistance

$\begin{array}{lll}\text { Year } & \text { Dept. } & \text { Purpose } \\ 2009 & \text { STA } & \text { National Accounts } \\ 2009 & \text { FAD } & \text { Fiscal Framework } \\ 2008 & \text { FAD } & \text { Customs Administration } \\ 2007 & \text { FAD } & \text { Intergovernmental Fiscal Relations } \\ 2007 & \text { FAD } & \text { Customs Administration } \\ 2007 & \text { FAD } & \text { Treasury } \\ 2007 & \text { MCM } & \text { Accounting and Budgeting Functions, BoM } \\ 2005 & \text { STA } & \text { National Accounts }\end{array}$

X. Resident Representative: None 


\section{ANNEX II. MEXICO-RELATIONS WITH THE WORLD BANK}

Mexico has had a longstanding partnership with the World Bank Group encompassing the delivery of the full menu of financial, knowledge, and coordination and convening services. Beginning in mid-2008, Mexico faced a deteriorating global environment and the parallel negative impacts of the food crisis and the influenza pandemic, as well as other internal issues related to organized crime. The IBRD was able to quickly respond to the need for increased financing by the federal government, while continuing to deliver on a broad knowledge agenda.

Crisis support has included higher levels of financing and Bank knowledge support. In responding to the crisis the program has evolved to include a few large DPLs and several quick-disbursing investment loans targeted to the poor. The program of support includes a major effort to alleviate the expected human consequences of the economic downturn, as well as efforts to promote the basis for gradual reactivation of the economy by strengthening the financial sector and supporting investment in infrastructure. At the same time, the Bank program responding as Mexico moves aggressively to mainstream climate change considerations in its infrastructure and social programs and to become a model and global champion for the climate change agenda. Going forward, strong demand for financing is likely to continue at least through calendar year 2010. Beyond 2010, a continuation of a strong knowledge and innovation-focused partnership is likely, but with a higher level of base financing as compared to pre-global crisis expectations.

As of January 31, 2010, Mexico was the Bank's second largest borrower with US\$ 10.5 billion debt outstanding, representing 9.2 percent of the IBRD's total portfolio. As of this date, Mexico had the seventh largest portfolio under supervision in terms of net IBRD commitments with US\$3,947 million of which US\$957 million remained undisbursed. The active portfolio comprised 15 projects. In the first half of FY10, the Bank approved three projects for a total amount of approximately US\$3.5 billion. FY10 total new lending is envisaged at US\$6.7 billion. The Progress Report for the FY08-13 Country Partnership Strategy (CPS) which was discussed in April 2008, will be circulated to the Board on March 25, 2010. 


\section{ANNEX III. MEXICO-STATISTICAL ISSUES}

The overall quality of Mexican statistics is good. A data ROSC for Mexico was completed on May 23, 2003 and was subsequently published as IMF Country Report No. 03/150. A data ROSC update was conducted in February 2010 and the draft report is being reviewed by the authorities. There are various areas where improvements could be made. The authorities are aware of this situation and are continuing work in this regard. Mexico observes the Special Data Dissemination Standards (SDDS) and its metadata are posted on the Dissemination Standards Bulletin Board (DSBB). In a number of cases, the periodicity and timeliness of disseminated data exceed SDDS requirements.

Although some items of the balance of payments statistics conform to the fifth edition of the Balance of Payments Manual, a full transition has not yet been completed. Several measures to improve external debt statistics have been carried out, including the compilation of data on external liabilities of the private sector and publicly traded companies registered with the Mexican stock exchange (external debt outstanding, annual amortization schedule for the next four years broken down by maturity, and type of instrument).

International reserves data are compiled according to the Operational Guidelines for the Data Template on International Reserves and Foreign Currency Liquidity of the IMF (2001).

The national accounts statistics generally follow the recommendations of the System of National Accounts, 1993 (1993 SNA). Source data and statistical techniques are sound and most statistical outputs sufficiently portray reality. A broad range of source data are available, with economic censuses every five years and a vast program of monthly and annual surveys. For most surveys, scientific sampling techniques are used. Nonetheless, most samples exclude a random sample of small enterprises. Changes in inventories are obtained as residuals, so there is no independent verification between the production and expenditure measures of GDP. Some statistical techniques need enhancement. For example taxes and subsidies on products at constant prices are estimated by applying the GDP growth rate; a deviation from best practice.

The concepts and definitions for both the CPI and PPI meet international standards. The PPI is only compiled by product and not by economic activity. ${ }^{1}$ Source data for the CPI and PPI are comprehensive and meet the needs for both indices.. Price and product specification data collected for the fortnightly price survey, as well as expenditure data collected for the ENIGH, are processed and audited according to procedures established as part of the total quality management system ISO 9001.

The authorities compile fiscal statistics following national concepts, definitions, and classifications that make international comparison difficult. The statistics are comprehensive and timely, except for states and municipalities. The new government accounting law mandates accounting standards that follow international standards for all levels of

\footnotetext{
1 The BANXICO has virtually completed an update of both the CPI and PPI in preparation for the transfer of the compilation of these series to INEGI. The new index series will not be officially published until July 2010.
} 
government, and that take into account the information needs of international organizations and national accounts.

The methodological foundations of monetary statistics are generally sound. However, the recording of financial derivative and, to a lesser extent, repurchase agreements transactions are overstating the aggregated other depository corporations (ODC) balance sheet and survey. The accuracy and reliability of the monetary statistics are supported by

comprehensive source data. The coverage of nonbank ODC is complete, but time delays in the submission of such data and the processing of the reports impedes timely dissemination of the ODC survey. Availability of quarterly data on other financial intermediaries such as insurance companies and pension funds allow for the construction of a financial corporations survey with full coverage of the Mexican financial system, which is published at the BM website on a regular basis. 


\section{MEXICO: TABLE OF COMMON INDICATORS REQUIRED FOR SURVEILLANCE}

AS OF FEBRUARY 26, 2010

\begin{tabular}{|c|c|c|c|c|c|c|c|}
\hline & \multirow{2}{*}{$\begin{array}{c}\text { Date of latest } \\
\text { observation }\end{array}$} & \multirow{2}{*}{ Date received } & \multirow{2}{*}{$\begin{array}{l}\text { Frequency of } \\
\text { Data }^{7}\end{array}$} & \multirow{2}{*}{$\begin{array}{l}\text { Frequency of } \\
\text { Reporting }^{7}\end{array}$} & \multirow{2}{*}{$\begin{array}{l}\text { Frequency of } \\
\text { publication }^{7}\end{array}$} & \multicolumn{2}{|c|}{ Memo Items: } \\
\hline & & & & & & $\begin{array}{c}\text { Data Quality }- \text { Methodological } \\
\text { soundness }^{8}\end{array}$ & $\begin{array}{l}\text { Data Quality Accuracy } \\
\text { and reliability } \\
\end{array}$ \\
\hline Exchange Rates & February 2010 & February 2010 & $\mathrm{D}$ & $\mathrm{D}$ & $\mathrm{D}$ & & \\
\hline $\begin{array}{l}\text { International Reserve Assets and Reserve Liabilities of the } \\
\text { Monetary Authorities }{ }^{1}\end{array}$ & January 2010 & February 2010 & M & M & M & & \\
\hline Reserve/Base Money & January 2010 & February 2010 & M & $\mathrm{D}, \mathrm{M}$ & $\mathrm{w}$ & \multirow[t]{4}{*}{$\mathrm{LO}, \mathrm{LO}, \mathrm{O}, \mathrm{O}$} & \multirow[t]{4}{*}{$\mathrm{LO}, \mathrm{O}, \mathrm{O}, \mathrm{O}, \mathrm{O}$} \\
\hline Broad Money & December 2009 & February 2010 & M & M & M & & \\
\hline Central Bank Balance Sheet & December 2009 & February 2010 & $\mathrm{w}$ & $\mathrm{w}$ & $\mathrm{w}$ & & \\
\hline Consolidated Balance Sheet of the Banking System & January 2010 & February 2010 & M & $\mathrm{M}$ & M & & \\
\hline Interest Rates ${ }^{2}$ & February 2010 & February 2010 & $\mathrm{D}$ & $\mathrm{D}$ & $\mathrm{D}$ & & \\
\hline Consumer Price Index & January 2010 & February 2010 & Bi-W & Bi-W & Bi-W & $\mathrm{O}, \mathrm{O}, \mathrm{LNO}, \mathrm{O}$ & LO, LNO, O, O, LNO \\
\hline $\begin{array}{l}\text { Revenue, Expenditure, Balance and Composition of Financing }{ }^{3} \\
- \text { General Government }^{4}\end{array}$ & & & & & & \multirow[t]{2}{*}{ LO, LNO, LNO, O } & \multirow[t]{2}{*}{$\mathrm{O}, \mathrm{O}, \mathrm{O}, \mathrm{O}, \mathrm{O}$} \\
\hline $\begin{array}{l}\text { Revenue, Expenditure, Balance and Composition of } \\
\text { Financing }{ }^{3}-\text { Central Government }\end{array}$ & December 2010 & January 2010 & M & $\mathrm{M}$ & M & & \\
\hline $\begin{array}{l}\text { Stocks of Central Government and Central Government- } \\
\text { Guaranteed Debt }{ }^{5}\end{array}$ & December 2010 & January 2010 & M & NA & M & & \\
\hline External Current Account Balance & Q4 2000 & February 2010 & Q & Q & Q & \multirow[t]{2}{*}{ LO, LO, LO, LO } & \multirow[t]{2}{*}{$\mathrm{LO}, \mathrm{O}, \mathrm{O}, \mathrm{O}, \mathrm{LO}$} \\
\hline Exports and Imports of Goods and Services & January 2010 & February 2010 & M & M & Bi-W & & \\
\hline GDP/GNP & Q4 2009 & February 2010 & Q & Q & Q & $\mathrm{O}, \mathrm{O}, \mathrm{LO}, \mathrm{O}$ & LO, LNO, O, LO, LO \\
\hline Gross External Debt & December 2009 & February 2010 & M & $\mathrm{M}$ & M & & \\
\hline International Investment Position ${ }^{6}$ & 2008 & June 2009 & A & A & A & & \\
\hline
\end{tabular}

1 Any reserve assets that are pledged of otherwise encumbered should be specified separately. Also, data should comprise short-term liabilities linked to a foreign currency but settled by other means as well as the notional values of financial derivatives to pay and to receive foreign currency, including those linked to a foreign currency but settled by other means.

2 Both market-based and officially determined, including discount rates, money market rates, rates on treasury bills, notes, and bonds.

3 Foreign, domestic bank, and domestic nonbank financing.

4 The general government consists of the central government (budgetary funds, extra budgetary funds, and social security funds) and state and local governments.

Including currency and maturity composition.

6 Includes external gross financial asset and liability positions vis-à-vis nonresidents.

7 Daily (D); Weekly (W); Monthly (M); Quarterly (Q); Annually (A); Irregular (I); Not Available (NA).

8 Reflects the assessment provided in the data ROSC published on May 23, 2003 and based on the findings of the mission that took place during February 20 to March 7, 2002. A new data ROSC update was conducted in February 2010 and the draft report is being reviewed by the authorities. For the dataset corresponding to the variable in each row, the assessment indicates whether international standards concerning (respectively) concepts and definitions, scope, classification/sectorization, and basis for recording are fully observed (O), largely observed (LO), largely not observed (LNO), or not observed (NO).

9 Same as footnote 8 , except referring to international standards concerning source data, assessment and validation of source data, statistical techniques, assessment and validation of intermediate data and statistical outputs, and revision studies. 
Public Information Notice (PIN) No. 10/39

FOR IMMEDIATE RELEASE

March 16, 2010
International Monetary Fund

$70019^{\text {th }}$ Street, NW

Washington, D. C. 20431 USA

\section{IMF Executive Board Concludes 2010 Article IV Consultation with Mexico}

On March 10, 2010, the Executive Board of the International Monetary Fund (IMF) concluded the Article IV consultation with Mexico. ${ }^{1}$

\section{Background}

Mexico had significantly strengthened policy credibility and public and private sector balance sheets before the onset of the crisis. Strong economic performance, with growth averaging over 3.5 percent in 2003-07, was underpinned by robust macro policy frameworks along with the flexible exchange rate regime. Considerable progress was made in improving debt profiles, and the strong regulatory framework gave rise to a sound banking sector.

Nevertheless, Mexico's resilience was severely tested during the global crisis. The surge in risk aversion following the collapse of Lehman Brothers in September 2008 triggered a sharp retrenchment of financial flows from emerging markets, including Mexico, resulting in liquidity strains and marked currency depreciation. Meanwhile, reflecting close U.S. linkages, Mexico experienced a rapid decline in manufacturing exports in the first half of 2009. Unanticipated large losses on corporate foreign exchange derivate positions disclosed in late 2008 further weighed on confidence, while the H1N1 virus outbreak in mid-

\footnotetext{
${ }^{1}$ Under Article IV of the IMF's Articles of Agreement, the IMF holds bilateral discussions with members, usually every year. A staff team visits the country, collects economic and financial information, and discusses with officials the country's economic developments and policies. On return to headquarters, the staff prepares a report, which forms the basis for discussion by the Executive Board. At the conclusion of the discussion, the Managing Director, as Chairman of the Board, summarizes the views of Executive Directors, and this summary is transmitted to the country's authorities. An explanation of any qualifiers used in summings up can be found here: http://www.imf.org/external/np/sec/misc/qualifiers.htm
} 
2009 put an additional drag on activity. Against this background, output contracted by $61 / 2$ percent in 2009, while the peso fell 25 percent against the dollar in the nine months to mid2009.

Prompt and effective policy measures were adopted in response to the crisis.

Macroeconomic policies were eased significantly, providing a fiscal impulse of 2.5 percent of GDP in 2009 and reducing policy rates by a total of $375 \mathrm{bps}$, to 4.5 percent, since mid2008. Targeted assistance was also extended to financial intermediaries to address funding shortages. At the same time, Mexico's Central Bank (Banxico) made substantial interventions (US $\$ 31.4$ billion in total) to maintain orderly liquidity conditions in the foreign exchange market, and secured contingent financing through the Federal Reserve swap line (\$30bn, expired in February 2010) and the Fund Flexible Credit Line (\$47bn, effective till mid-April 2010) to further support confidence. On the back of these strong policy measures, growth has resumed since mid-2009, the peso exchange rate has rebounded, while domestic financial stability has been maintained.

Building on the recent momentum, activity is expected to accelerate in the near term, leading to projected growth of 4 percent for 2010. Inflation was pushed up to $4 \frac{1}{2}$ percent in January 2010 by one-off increases in taxes and administered prices, but is expected to return to the 3 percent target by end-2011 reflecting the considerable economic slack. With domestic demand gradually strengthening, the current account deficit is projected to widen slightly to $1 \frac{1}{2}$ percent of GDP in 2010.

The authorities have also undertaken a series of measures to further bolster fundamentals and rebuild buffers. The FY2010 budget included a substantive tax reform, designed to offset the revenue losses from lower oil production, while allowing for a temporary easing of the balanced budget rule in response to the cyclical downturn. Requirements on corporate disclosure of derivative exposures has been tightened, while structural reforms to enhance growth potential-most recently reforms of the electricity sector-are being advanced. In addition, the authorities have announced plans to increase foreign exchange reserves gradually through a combination of retaining public sector foreign exchange cash flows and the use of an options-based mechanism.

\section{Executive Board Assessment}

Executive Directors commended the authorities for their sound policy frameworks and progress in strengthening public and private sector balance sheets, which had enabled an effective counter-cyclical policy response and helped preserve stability during the crisis. Their swift action to secure contingency credit lines-from the U.S. Federal Reserve and the Fund-has also helped maintain external confidence. The economy is starting to recover, following the deep output contraction in the first half of 2009. However, the uncertain global outlook could pose downside risks, underscoring the need to increase 
room for policy maneuver and strengthen efforts to address medium-term fiscal and growth challenges.

Directors considered that the 2010 budget is appropriate. The tax package represents an important step toward achieving medium-term fiscal sustainability, while the temporary easing of the balanced budget, in accordance with the exceptional clause of the fiscal rule, would help cushion the impact of the withdrawal of fiscal support. Directors welcomed the progress in fiscal reforms over the past three years. Given the expected structural declines in oil revenues and rising current spending pressures, they welcomed plans to seek expenditure savings and further strengthen tax administration. Further efforts would be needed to advance on oil sector reforms, broaden the tax base, and simplify the tax system. Moving to a structural budget rule would help reduce procyclicality and spending volatility, further strengthening policy credibility. Directors saw the removal of the caps on savings in the oil stabilization funds as a step in the right direction.

In light of the still weak demand conditions, Directors agreed that monetary policy should remain supportive until the recovery is firmly established. The central bank's effective communication has helped limit the effects on inflation of the recent changes in taxes and administered prices. Nevertheless, second-round effects would need to be carefully monitored.

Directors agreed that the flexible exchange rate has played an important role in the adjustment process, and welcomed the transparent, rules-based intervention mechanisms. Noting persistent market concerns about Mexico's low reserve coverage relative to balance sheet indicators, many Directors saw merit in the authorities' plan to explore options for further strengthening foreign exchange buffers. A number of other Directors pointed to the need to take due account of the costs and externalities of reserve accumulation.

Directors noted that the financial system remains resilient, underpinned by strong regulation and supervision. They welcomed the authorities' prompt action to address emerging issues in some small nonbank institutions, and encouraged continued close monitoring of developments in this sector. Directors supported the intentions to broaden the regulatory perimeter, set up a committee for assessing systemic risks, and reform the financial sector resolution framework.

Directors emphasized that the challenge of reinvigorating growth has gained new urgency in a weak global environment. They encouraged the authorities to expedite structural reforms to boost growth, building on recent important steps to improve productivity in the electricity sector. Key priorities include advancing on strengthening the competition framework, streamlining the regulatory framework, and enhancing labor market flexibility. 
Public Information Notices (PINs) form part of the IMF's efforts to promote transparency of the IMF's views and analysis of economic developments and policies. With the consent of the country (or countries) concerned, PINs are issued after Executive Board discussions of Article IV consultations with member countries, of its surveillance of developments at the regional level, of post-program monitoring, and of ex post assessments of member countries with longer-term program engagements. PINs are also issued after Executive Board discussions of general policy matters, unless otherwise decided by the Executive Board in a particular case. The staff report (use the free Adobe Acrobat Reader to view this pdf file) for the 2010 Article IV Consultation with Mexico is also available. 


\section{Mexico: Selected Economic and Financial Indicators 1/}

\begin{tabular}{|c|c|c|c|c|c|c|}
\hline & 2004 & 2005 & 2006 & 2007 & 2008 & 2009 \\
\hline \multicolumn{7}{|c|}{ (Annual percentage changes, unless otherw ise indicated) } \\
\hline \multicolumn{7}{|l|}{ National accounts and prices } \\
\hline Real GDP & 4.0 & 3.2 & 4.9 & 3.3 & 1.5 & -6.5 \\
\hline Real GDP per capita 2/ & 2.7 & 3.4 & 4.2 & 2.4 & 0.5 & -7.3 \\
\hline Gross domestic investment (in percent of GDP) & 24.8 & 24.4 & 26.1 & 25.8 & 26.4 & 22.1 \\
\hline Gross national savings (in percent of GDP) & 24.1 & 23.8 & 25.7 & 25.0 & 24.9 & 21.4 \\
\hline Consumer price index (end period) & 5.2 & 3.3 & 4.1 & 3.8 & 6.5 & 3.6 \\
\hline \multicolumn{7}{|l|}{ External sector } \\
\hline Exports, f.o.b. 3/ & 14.1 & 14.0 & 16.7 & 8.8 & 7.2 & -21.2 \\
\hline Imports, f.o.b. 4/ & 15.4 & 12.7 & 15.4 & 10.1 & 9.5 & -24.0 \\
\hline External current account balance (in percent of GDP) & -0.7 & -0.5 & -0.5 & -0.8 & -1.5 & -0.6 \\
\hline Change in net international reserves (end of period, billions of U.S. dollars) & -4.1 & -7.2 & 1.0 & -10.3 & -7.5 & -5.4 \\
\hline Outstanding external debt (in percent of GDP) & 21.9 & 20.4 & 17.8 & 18.8 & 18.5 & 23.8 \\
\hline \multicolumn{7}{|l|}{ Total debt service ratio $5 /$} \\
\hline (in percent of exports of goods, services, and transfers) & 30.8 & 25.9 & 30.3 & 23.0 & 23.0 & 28.3 \\
\hline \multicolumn{7}{|l|}{ Nonfinancial public sector (in percent of GDP) } \\
\hline Augmented overall balance & -1.6 & -1.4 & -1.0 & -1.4 & -1.5 & -4.7 \\
\hline Traditional overall balance & -0.2 & -0.1 & 0.1 & 0.0 & -0.1 & -2.3 \\
\hline Gross augmented public sector debt & 41.4 & 39.8 & 38.3 & 38.2 & 43.3 & 44.6 \\
\hline Net augmented public sector debt & 36.8 & 35.2 & 32.4 & 31.4 & 35.8 & 38.8 \\
\hline \multicolumn{7}{|l|}{ Money and credit } \\
\hline Monetary base & 12.0 & 11.7 & 18.4 & 10.0 & 16.7 & 9.4 \\
\hline Broad money (M4a) & 12.6 & 15.0 & 12.8 & 11.5 & 17.2 & 5.9 \\
\hline Treasury bill rate (28-day cetes, in percent, annual average) & 6.8 & 9.2 & 7.2 & 7.2 & 7.5 & 5.4 \\
\hline
\end{tabular}

Sources: National Institute of Statistics and Geography; Bank of Mexico; and Ministry of Finance and Public Credit; and IMF staff estimates.

$1 /$ Methodological differences mean that the figures in this table may differ from those published by the authorities. 2/ Fund staff estimates.

3/ Exports net of maquila sector imports.

4/ Excludes maquila sector imports.

5/ Public and private sectors. 